\title{
Site U1318
}

\author{
Expedition 307 Scientists $^{2}$
}

\section{Chapter contents}

Background and objectives.......... 1

Operations................. 1

Lithostratigraphy.............. 2

Biostratigraphy ............... 5

Paleomagnetism ............... 7

Geochemistry and microbiology. . . . . . . 7

Physical properties ............... 11

Downhole measurements............ 14

References.................... 16

Figures..................... 17

Tables......................49

${ }^{1}$ Expedition 307 Scientists, 2006. Site U1318. In Ferdelman, T.G., Kano, A., Williams, T., Henriet, J.-P., and the Expedition 307 Scientists. Proc. IODP, 307: Washington, DC (Integrated Ocean Drilling Program Management International, Inc.). doi:10.2204/iodp.proc.307.105.2006

'Expedition 307 Scientists' addresses.

\section{Background and objectives}

Site U1318 (proposed Site PORC-2A; 51 $26.16^{\prime} \mathrm{N}, 11^{\circ} 33.0^{\prime} \mathrm{W} ; 423$ $\mathrm{m}$ water depth) is located on the eastern slope of Porcupine Seabight on the southwest continental margin of Ireland (Fig. F1) and is upslope from the Belgica mound province, including Challenger Mound. Sediments were expected to consist of silty clay and nannofossil- and microfossil-bearing ooze intercalated with sandy and terrigeneous sediments, possibly with diagenetic carbonates.

The three main seismic units, P1, P2, and P3, are encountered at Site U1318 (Fig. F2) (see the "Site U1316" chapter). Unit P1 is characterized by a series of parallel, continuous layers of low amplitude. At this site, the base of Unit P1 is formed by a series of sigmoid-shaped bodies. Unit P2 is characterized by a nearly transparent acoustic facies on top of the erosional unconformity bounding Units P1 and P2. Only a few sets of continuous, relatively high amplitude reflectors are observed inside Unit P2. The uppermost seismic Unit P3, characterized by slightly upslope migrating wavy parallel reflectors, represents Quaternary drift deposits (Von Rooij et al., 2003).

The principal objective at Site U1318 was to recover the sediments from the three seismic units (P1-P3) of the southern Belgica mound province. Complete data from the seismically low amplitude layer (Unit P2) would allow refinement of the paleoenvironmental history before initiation of Challenger Mound.

\section{Operations}

The rig was secured for transit and the vessel was under way from Site U1316 to Site U1318 on 8 May. After a $7 \mathrm{nmi}$ transit, the vessel came on site and the thrusters were lowered and the vessel was positioned over the site coordinates.

\section{Hole U1318A}

A positioning beacon was dropped at 1649 h on 8 May 2005, beginning Hole U1318A. The precision depth recorder provided a seafloor depth of 430.4 meters below rig floor (mbrf). An advanced piston corer (APC)/extended core barrel (XCB) bottomhole assembly (BHA) was made up with two stands of collars. Hole U1318A was spudded at 2045 h on 8 May, and a seafloor depth was established at 420.3 mbrf. 
Fifteen APC cores advanced to total depth (TD) at 142.2 meters below seafloor (mbsf) (562.5 mbrf; recovery $=90 \%)$. Perfluoromethylcyclohexane tracer (PFT) and microsphere tracers were run on all cores, APC temperature measurements were taken at 28.2, 56.7, 85.2, and $113.7 \mathrm{mbsf}$, and the Tensor orientation tool took measurements from 28.2 to 123.2 mbsf. Overpulls were required on five cores, two of those on the temperature runs. The drill string was pulled clear of the seafloor at $0905 \mathrm{~h}$ on 9 May, officially ending operations in Hole U1318A.

\section{Hole U1318B}

The drillship was offset $20 \mathrm{~m}$ south of Hole U1318A. After the drill string was spaced out, Hole U1318B was spudded at $1010 \mathrm{hr}$ on 9 May 2005, and the seafloor was established at 419.8 mbrf.

Fourteen APC cores advanced to 128.5 mbsf (548.3 mbrf; recovery $=94 \%)$. No tracers were run during APC coring, and the Tensor orientation tool took measurements from 24.0 to 128.5 mbsf. Overpulls were required on two cores. The coring assembly was switched to XCB. Cores $15 \mathrm{X}$ and $16 \mathrm{X}$ had virtually no recovery. The XCB cutting shoe spacer and flow sleeve were reconfigured and recovery increased to $100 \%$. PFT and microsphere tracers began on Core 19X (176.5 mbsf) and ended on Core 26X (235.0 mbsf). Thirteen XCB cores advanced an additional $116.1 \mathrm{~m}$ to TD at $244.6 \mathrm{mbsf}$ (644.4 mbrf) at $0630 \mathrm{~h}$ on 10 May (recovery $=79 \%$ ).

Hole U1318B was prepared for logging. A wiper trip was run from bottom up to $60 \mathrm{mbsf}$ and back to bottom. There were no hole problems, and only $1 \mathrm{~m}$ of fill was circulated out. The hole was displaced with $102 \mathrm{bbl}$ of sepiolite mud, and the drill pipe was tripped to the logging depth of $70 \mathrm{mbsf}$.

The Schlumberger wireline logging sheaves were rigged up, and the triple combination (triple combo) tool string was assembled. As the logging string was run in the hole, it took weight at 70 and 96 mbsf. The tools worked their way through the restrictions and were able to get to TD at $244.6 \mathrm{mbsf}$. From TD the triple combo logged upward to $70 \mathrm{mbsf}$. The data quality was good, so a second pass was not necessary. The tools were pulled out of the hole and laid out.

The second logging run was with the Formation MicroScanner (FMS)-sonic tool string. The FMS-sonic tool string was assembled and run to bottom with no problems. Two passes were made from 244 to 87 mbsf. The logging string was pulled out of the hole and laid out. The Schlumberger wireline logging sheaves were rigged down, ending the logging operations at $1855 \mathrm{~h}$ on 10 May.
The drill pipe was tripped out of the hole and pulled clear of seafloor at $2110 \mathrm{~h}$ on 10 May, ending operations in Hole U1318B.

\section{Hole U1318C}

The vessel was offset $25 \mathrm{~m}$ south of Hole U1318B, and the drill string was spaced out for spudding. Hole U1318C was spudded with the APC at $2245 \mathrm{~h}$ on 10 May 2005, and a seafloor depth of $420.9 \mathrm{mbrf}$ was established.

A center bit was dropped and the hole was washed/ drilled down to 70.0 mbsf. The center bit was retrieved with the wireline, and seven APC cores advanced an additional $58.6 \mathrm{~m}$ to $125.7 \mathrm{mbsf}$ (546.6 mbrf; recovery $=93 \%)$. No PFT or microsphere tracers were run, and the Tensor orientation tool took measurements from 79.5 to 125.7 mbsf. Overpulls were required on two cores, so the coring assembly was switched to XCB. Three XCB cores advanced an additional $28.8 \mathrm{~m}$ to TD at $154.5 \mathrm{mbsf}$ (575.4 mbrf). The drill string was pulled clear of the seafloor at $0900 \mathrm{~h}$ on 11 May. The positioning beacon was released and recovered on deck at $0920 \mathrm{~h}$, the drill pipe was tripped to surface, and the BHA was racked back. The rig was secured for transit to Site U1317 at $1015 \mathrm{~h}$ on 11 May, ending operations at Site U1318 (Table T1).

\section{Lithostratigraphy}

Site U1318 is located upslope of Challenger Mound in water depths of 408.8-409.9 $\mathrm{m}$ and represents the shallowest sedimentary package of the slope transect. Principal objectives of this site were to recover sediments from the low-amplitude seismic unit (P2) (Van Rooij et al., 2003) and to constrain the age of the unconformities identified as erosional surfaces in the seismic profile. Hole U1318A was drilled continuously to $142.2 \mathrm{mbsf}$, and 15 cores were taken with a recovery of $90.2 \%$. Hole U1318B was cored to 244.6 mbsf with a total of 27 cores and a recovery of 87.1\%. In Hole U1318C, after establishing the mudline in Core $307-1318 \mathrm{C}-1 \mathrm{H}$, the drill string washed down to $70.0 \mathrm{mbsf}$ and core recovery continued to 154.5 mbsf with 10 cores and a recovery of $96.3 \%$.

The sediments from Site U1318 are divided into three units (Table T2) based on visual description of the sedimentary features and composition, biostratigraphic constraints, and correlation to the magnetic susceptibility and carbonate content data. They are the upper Pleistocene clay (Unit 1), the lower Pleistocene thin sandy layers (Unit 2), and the lower Miocene (to possible Pliocene) silty clay as much as 155 $\mathrm{m}$ thick (Unit 3) (Fig. F3). 
Significant changes in magnetic susceptibility and carbonate content are recognized at a major unconformity located just above a bivalve bed at 86.7, 86.2, and 84.2 mbsf in Holes U1318A, U1318B, and U1318C, respectively. The unconformity defines the boundary between Units 2 and 3 .

\section{Lithostratigraphic units}

\section{Unit 1}

Intervals: Sections 307-U1318A-1H-1, $0 \mathrm{~cm}$, through 9H-3, $22 \mathrm{~cm}$; and 307-U1318B-1H-1, $0 \mathrm{~cm}$, through $10 \mathrm{H}-1,100 \mathrm{~cm}$

Depths: Hole U1318A: 0-78.9 mbsf and Hole U1318B: 0-82.0 mbsf

Age: $<0.26 \mathrm{Ma}$; after first-appearance datum (FAD) of Emiliania huxleyi (see "Biostratigraphy")

Unit 1 is dominated by an unlithified clayey succession divided into three subunits with distinct boundaries. Boundaries among three subunits correspond to shifts in the magnetic susceptibility record (see "Paleomagnetism").

\section{Subunit $1 A$}

Intervals: Sections 307-U1318A-1H-1, $0 \mathrm{~cm}$, through $4 \mathrm{H}-5,24 \mathrm{~cm}$; and 307-U1318B-1H-1, $0 \mathrm{~cm}$, through $5 \mathrm{H}-2,2 \mathrm{~cm}$

Depths: Hole U1318A: 0.0-33.3 mbsf and Hole U1318B: 0.0-35.0 mbsf

Age: $<0.26 \mathrm{Ma}$; after FAD of E. huxleyi (see "Biostratigraphy")

Subunit $1 \mathrm{~A}$ is dominated by dark grayish brown to dark gray silty clays, which are partly interbedded with centimeter-thick fine-sand layers occasionally grading upward. The sediments are dominantly massive but contain some laminated intervals. Centimeter- to millimeter-thick laminae consist of light and dark greenish gray clay with very fine sand layers representing small-scale fining-upward cycles. Bioturbation in the laminated horizons is rare. In contrast, massive horizons are moderately to strongly bioturbated. Dropstones are frequently found in this subunit. Fossils are generally rare and dispersed. Mollusk shells, up to $3 \mathrm{~cm}$, rarely occur in the upper 15 $\mathrm{m}$. Black spots, aggregations of fine iron sulfide grains, are common. The base of the subunit is defined by an erosive boundary overlain by a $24 \mathrm{~cm}$ thick graded fine sand to clayey silt layer (Fig. F4A). The same sedimentary package is identified in Section 307-U1316B-5H-2, $2 \mathrm{~cm}$.

\section{Subunit $1 B$}

Intervals: Sections 307-U1318A-4H-5, $24 \mathrm{~cm}$, through 7H-3, $60 \mathrm{~cm}$; and 307-U1318B-5H-2, $2 \mathrm{~cm}$, through $8 \mathrm{H}-1,0 \mathrm{~cm}$
Depths: Hole U1318A: 33.30-61.7 mbsf and Hole U1318B: 35.03-62.0 mbsf

Age: $<0.26 \mathrm{Ma}$; after FAD of E. huxleyi (see "Biostratigraphy")

The lithology of Subunit 1B comprises dark grayish brown to very dark gray silty clays that are similar to facies of Subunit 1A. In contrast to Subunit 1A, dropstones are much less frequent and laminated horizons are more frequent in this subunit. Lamination occurs on a centimeter to millimeter scale (Fig. F4B). Fossils are rare throughout the subunit. Several white fine-sand layers, only 1-2 $\mathrm{mm}$ thick, are found at $\sim 58$ and $\sim 57$ mbsf in Holes U1318A and U1318B, respectively. These layers consist of reworked volcanic glasses. Unfortunately, the lower boundary of this subunit was not recovered because of onboard sampling in Hole U1318A and the core boundary between Cores 307-U1318B-7H and 8H.

\section{Subunit 1C}

Intervals: Sections 307-U1318A-7H-4, $0 \mathrm{~cm}$, through 9H-3, $22 \mathrm{~cm}$; and 307-U1318B-8H-1, $0 \mathrm{~cm}$, through $10 \mathrm{H}-1,100 \mathrm{~cm}$

Depths: Hole U1318A: 63-78.9 mbsf and Hole U1318B: 62-82.0 mbsf

Age: $<0.26 \mathrm{Ma}$; after FAD of E. huxleyi (see "Biostratigraphy")

The lithology of Subunit 1C is characterized by alternating dark grayish brown fine sandy clay and very dark grayish brown silty clay. This subunit can be distinguished by coarser grain sizes in comparison to Subunits $1 \mathrm{~A}$ and $1 \mathrm{~B}$. Laminations of fine sand and silty clay are dominant in the middle part of Subunit 1C from 64 to 77 mbsf. Lamination thickness varies from millimeter to centimeter scale. Dropstones are absent. The base of the subunit is defined by a sharp, erosive boundary at 82 mbsf in Section 307-U1318B$10 \mathrm{H}-1,100 \mathrm{~cm}$.

\section{Unit 2}

Intervals: Sections 307-U1318A-9H-4, $0 \mathrm{~cm}$, through $10 \mathrm{H}-2,0 \mathrm{~cm} ; 307-\mathrm{U} 1318 \mathrm{~B}-10 \mathrm{H}-1$, $100 \mathrm{~cm}$, through $10 \mathrm{H}-4,72 \mathrm{~cm}$; and $307-$ $\mathrm{U} 1318 \mathrm{C}-3 \mathrm{H}-1,45 \mathrm{~cm}$, to $3 \mathrm{H}-4,18 \mathrm{~cm}$

Depths: Hole U1318A: 80.7-86.7 mbsf, Hole U1318B: 82.0-86.2 mbsf, and Hole U1318C: 79.9-84.2 mbsf

Age: 0.96-1.22 Ma; small Gephyrocapsa Zone (see "Biostratigraphy")

Unit 2 is dominated by olive-gray, medium-fine sand interbedded with dark yellowish brown silty clay. A gradual increase in sand indicates a coarsening-upward trend throughout this unit. A 
majority of the sand beds are normal graded with sharp lower and upper boundaries. Lithoclasts, up to $3 \mathrm{~cm}$ in diameter, are found in both sand and clay horizons. Sand beds commonly contain wellpreserved mollusk and other unidentified shell fragments. Notably, a $6 \mathrm{~cm}$ long gastropod retained its pale yellow color in Section 307-U1318A-9H-6, 64 $\mathrm{cm}$ (Fig. F4C). The base of this subunit consists of a conglomerate, $5-10 \mathrm{~cm}$ thick, with black pebbles and granules. Black angular to subangular gravels consist of a mixture of apatite, calcite, and quartz based on X-ray diffraction (XRD) analyses. The boundary is defined just above the bivalve bed in the uppermost part of Unit 3 and is associated with a major unconformity between Tertiary (Pliocene or Miocene) and Pleistocene sediments. Detailed calcareous nannofossil data revealed that the conglomerate of this unit is $0.96-1.22 \mathrm{Ma}$ and that the wellsorted fine sand just beneath the bivalve bed is older than 3.6 Ma (see "Biostratigraphy"). The relationship between the conglomerate and the underlying bivalve bed is best expressed in Section 307-U1318B$10 \mathrm{H}-4$, whereas in Hole U1318A, the same feature is disturbed by the section boundary between $10 \mathrm{H}-2$ and 10H-1 (Fig. F5).

\section{Unit 3}

Intervals: Sections 307-U1318A-10H-2, $0 \mathrm{~cm}$, to $15 \mathrm{H}-5,56 \mathrm{~cm} ; 307-\mathrm{U} 1318 \mathrm{~B}-10 \mathrm{H}-4,72 \mathrm{~cm}$, to $27 \mathrm{X}-\mathrm{CC}, 29 \mathrm{~cm}$; and 307-U1318C-3H-4, 18 $\mathrm{cm}$, to 10X-CC, $41 \mathrm{~cm}$

Depths: Hole U1318A: 86.7-138.5 mbsf, Hole U1318B: 86.2-241.0 mbsf, and Hole U1318C: 84.2-154.5 mbsf

Age: 3.6-15.6 Ma; according to calcareous nannofossils (see "Biostratigraphy")

Unit 3 is divided into three subunits based on the differences observed within the carbonate content (Fig. F3) (see "Geochemistry and microbiology"). Subunit 3A generally consists of silty clay, fine sands, and clayey silt with carbonate contents of 27-50 $\mathrm{wt} \%$. The uppermost $10 \mathrm{~cm}$ interval of Subunit 3A is a prominent bivalve bed that is unconformably overlain by the basal conglomerate of Unit 2. Subunit 3B is homogeneous greenish gray silty clay with a carbonate content of 10-22 wt $\%$. The bottom section of the core, Subunit 3C, consists of greenish gray silty clays to fine sands with some dolomitic horizons. Carbonate content is 21-35 wt \%, except for strongly lithified horizons, which have carbonate contents of $\sim 70 \mathrm{wt} \%$. Sediments are moderately lithified throughout Unit 3, except for several well lithified horizons in Subunit 3C.

\section{Subunit $3 A$}

Intervals: Sections 307-U1318A-10H-2, $0 \mathrm{~cm}$, through $14 \mathrm{H}-4,51 \mathrm{~cm} ; 307-\mathrm{U} 1318 \mathrm{~B}-10 \mathrm{H}-4$, $72 \mathrm{~cm}$, through $14 \mathrm{H}-\mathrm{CC}, 16 \mathrm{~cm}$; and $307-$ U1318C-3H4, $18 \mathrm{~cm}$, through $8 \mathrm{X}-2,16 \mathrm{~cm}$

Depths: Hole U1318A: 86.7-128.3 mbsf, Hole U1318B: 86.2-127.4 mbsf, and Hole U1318C: 84.2-127.3 mbsf

Age: 3.6-15.6 Ma according to calcareous nannofossils; $<3.2 \mathrm{Ma}$ according to planktonic foraminifers (see "Biostratigraphy")

The sediments of Subunit 3A are mostly composed of greenish gray to light greenish gray silty clays interbedded with well-sorted greenish gray fine sand and greenish gray to gray silt that have erosive boundaries at their bases. The frequency of sandy and silty beds increases upward. This subunit is characterized by high grain-size variability and carbonate contents. Carbonate contents increase from $\sim 30 \mathrm{wt} \%$ at the bottom to $\sim 45 \mathrm{wt} \%$ at the middle of the subunit (Fig. F3). Shell fragments and other bioclasts sporadically occur throughout the subunit. A prominent bivalve bed $\sim 10 \mathrm{~cm}$ thick overlies well-sorted fine sand at the uppermost horizon of Subunit 3A. Bone bivalves are characterized by their black "steinkern" (internal cast), whereas in others, the shell belt is still preserved. The cast material was identified as a mixture of apatite, calcite, and quartz by XRD analysis. Thick-walled shells rarely occur within silty clay sediments in the upper part of Subunit 3A. Burrows are clearly visible because of the variable lithologic components. The base of Subunit $3 \mathrm{~A}$ is defined by a sharp erosive boundary at 127.3 mbsf in Hole U1317C, yet was not recovered in Holes U1318A and U1318B.

\section{Subunit 3B}

Intervals: Sections 307-U1318A-14H-4, $51 \mathrm{~cm}$, through 15H-5, $56 \mathrm{~cm}$; 307-U1318B-14H$\mathrm{CC}, 16 \mathrm{~cm}$, to $21 \mathrm{H}-3,114 \mathrm{~cm}$; and $307-$ U1318C-8X-2, $16 \mathrm{~cm}$, through 10X-CC, 41 $\mathrm{cm}$

Depths: Hole U1318A: 120.7-138.5 mbsf, Hole U1318B: 121.0-190.3 mbsf, and Hole U1318C: $127.3-154.5 \mathrm{mbsf}$

Age: early-middle Miocene; $13.6-15.6$ Ma by calcareous nannofossils, $14.8-16.0$ Ma by planktonic foraminifers (see "Biostratigraphy")

Subunit 3B is a very homogeneous greenish gray silty clay with carbonate contents of $\sim 20 \mathrm{wt} \%$ in the upper half and $\sim 10 \mathrm{wt} \%$ in the lower. The uppermost and lowermost few meters of Subunit 3B comprise sands with some bioclasts. Bioturbation is abundant 
throughout the subunit (Fig. F4D). Some burrows are infilled with iron sulfide concretions.

\section{Subunit $3 C$}

Interval: Sections 307-U1318B-21X-3, $114 \mathrm{~cm}$, through 27X-CC, $29 \mathrm{~cm}$

Depth: 190.3-241.0 mbsf

Age: early-middle Miocene; 13.6-15.6 Ma by calcareous nannofossils (see "Biostratigraphy")

Subunit 3C is characterized by a greenish gray silty clay to fine sand with carbonate contents from $\sim 25$ $\mathrm{wt} \%$ at the top to $\sim 35 \mathrm{wt} \%$ at the bottom. A density decrease of fine sand beds indicates a fining-upward trend from the middle to upper part of the succession. Fossils are generally rare and dispersed. Bioturbation is abundant to moderate. There are some extremely lithified beds with carbonate contents of $\sim 70$ $w t \%$ in the middle of the subunit. Two of these are dolomite-bearing horizons at 223.7 and 228 mbsf, which are markedly more lithified and lighter in color. The thin section from this horizon shows dense appearance of dolomite.

\section{Discussion}

This discussion is focused on (1) the facies change in Unit 1, (2) the major unconformity between Units 2 and 3, and (3) the extremely lithified horizons found in lower part of Unit 3.

\section{Lamination and bioturbation in Unit 1}

The alternating laminated and bioturbated massive intervals in the upper Pleistocene Unit 1 reflects periodic variations in the depositional environment. Further studies will reveal whether these variations reflect differences in seafloor oxygenation, and depositional ratios, which may be related to glacial-interglacial cycles. The ice-rafted dropstones suggest a positive correlation of dropstone density with bioturbated massive intervals, although the correlation is not always straightforward.

\section{Phosphatic bivalve bed}

The major unconformity that separates the lower Pleistocene clay from the underlying Tertiary (Pliocene-Miocene) strata is defined at the phosphatic bivalve bed at $\sim 86 \mathrm{mbsf}$ at Site U1318. Figure F5 summarizes a detailed sedimentary succession with biostratigraphic ages above and below the bivalve bed. The bivalves have not been further identified. Efforts to classify them in detail and evaluate their ecological significance will be part of postcruise research. Calcareous nannofossil data indicate that well-sorted fine sand just beneath the shell bed is older than 3.6 Ma. One sample including both Pleistocene and Miocene species indicates sediment mixing by bioturbation. Burrows incised into this fine sand are filled with brownish sands derived from the Pleistocene dark grayish brown fine sand. In contrast, the basal conglomerate just above the shell bed is 0.96-1.22 Ma. These findings mark a major hiatus just below or above the shell bed. Precipitation of phosphatic minerals associated with the bivalves and angular to subangular phosphatic gravels of the basal conglomerate suggest some changes in oceanographic conditions. Future research, such as measurements of stable isotopes and minor elements, will elucidate the history of this sedimentary succession.

\section{Lithification}

The composition of indurated zones encountered in the premound strata at Sites U1316 and U1318 is indicated by smear slide and thin section analysis. These zones are composed primarily of silt-sized quartz and feldspar grains and clay-sized material cemented by a calcite and dolomite microspar composed of micrometer- to decimicrometer-sized crystals. In Cores 307-U1318C-24H and 25H, lithified zones overlie and underlie unlithified silty clays composed dominantly of coccoliths. Coccoliths are uncommon to absent in the lithified zones. We speculate that lithification occurred when coccolithic muds underwent aggrading neomorphism, destroying their original texture and forming microspar. Surface energy-driven recrystallization (Ostwalt ripening) is likely the driving mechanism for the recrystallization, but we can offer no reasons at this time as to why particular zones underwent this process as well as partial dolomitization.

When the stratigraphic column is projected on the seismic profile, the boundary between Subunits 3B and $3 \mathrm{C}$ can be roughly correlated to the boundary between seismic Units P2 and P1 (Fig. F9). An unconformity suggested by a seismic study of Van Rooij et al. (2003) is not evident in the preliminary lithostratigraphic and biostratigraphic investigation during Expedition 307 (Fig. F2). The P2/P1 boundary may instead correspond to the interval of change in lithification degree.

\section{Biostratigraphy}

Core catcher samples from each core of Holes U1318A and U1318B were examined for nannofossils, and Hole U1318A was examined for planktonic and benthic foraminifers. In several intervals, higher resolution sampling was performed in order to better constrain hiatus horizons. Nannofossils are moder- 
ately to well preserved in all sediments, except in Sections 307-U1318B-21X-CC (195.5 mbsf) and 27XCC (241.1 mbsf), which display poor preservation. The preservation of planktonic foraminifers in Hole U1318A is very good to moderate. Samples from the upper part of Hole U1318A (Samples 307-U1318A1H-CC, 2H-CC, 4H-CC, 7H-CC, and 8H-CC) contain low abundances of planktonic foraminifers, but in other samples they are common to very abundant.

\section{Calcareous nannofossils}

The middle to upper Pleistocene E. huxleyi Zone (recent-0.26 Ma) is represented by material recovered from Sections 307-U1318A-1H-CC (8.9 mbsf) through 8H-CC (73.6 mbsf) (Fig. F6; Table T3). These sections contain an abundance of reworked Late Cretaceous nannofossils. The lower Pleistocene small Gephyrocapsa Zone (0.96-1.22 Ma) is found only in Sample 307-U1318A-9H-CC (84.6 mbsf) (Fig. F6; Table T3).

The sediment at 104.3 mbsf (Sample 307-U1318A$11 \mathrm{H}-\mathrm{CC}$ ) in Hole U1318A yields two diagnostic genera, Sphenolithus spp. and Reticulofenestra spp., with a well-established last occurrence at 3.6 Ma (Table T3). This indicates that sediments below 104.3 mbsf in Hole U1318A are at least older than late Pliocene. The absence of traditional marker taxa made it difficult to derive an age for the underlying sediment in Sections 307-U1318A-11H-CC to $13 \mathrm{H}-\mathrm{CC}$. We very tentatively assign an age to this sediment that falls within the early middle Miocene. This assignment is based on the presence of taxa characteristic of this time period, which include Cyclicargolithus floridanus, Reticulofenestra gartnerii, and Helicosphaera scissura. At 86.2 mbsf in Hole U1318B, there is an obvious hiatus recorded both in the nannofossil record and as an erosion surface in the lithologic record. Results of high-resolution sampling in Hole U1318B locate the horizon of this hiatus between Samples 307U1318B-10H-4, $70 \mathrm{~cm}$ (86.20 mbsf) and $10 \mathrm{H}-4,83$ $\mathrm{cm}$ (86.33 mbsf), which coincides with the lithostratigraphic boundary between Units 2 and 3 (see "Lithostratigraphy").

The lower middle Miocene Zone CN3 is represented in Samples 307-U1318B-14H-CC (127.3 mbsf) through 20X-CC (186.0 mbsf) (Fig. F6). The sediments of this interval commonly yield the diagnostic taxa Sphenolithus hetermorphus, Helicosphaera ampliaperta, Discoaster deflandrei, R. gartnerii, and $C$. floridanus (Fig. F6; Table T3).

Preservation of nannofossils in Samples 307U1318B-21X-CC (195.5 mbsf) and 27X-CC (241.1 mbsf) was very poor, and an age datum could not be derived for this sediment.

\section{Planktonic foraminifers}

The sediments in Hole U1318A yield PleistoceneMiocene planktonic foraminifers (Fig. F7; Table T4). The Cenozoic mid-latitude Zones SN14 and SN13 (Jenkins, 1985, 1993), were assigned for sediment above Section 307-U1318A-12H-CC (112.5 mbsf) by the occurrence of Globorotalia inflata (Fig. F7; Table T4). This interval includes the boundary between the upper Pliocene (Zone SN13) and Pleistocene (Zone SN14) (Fig. F6). We could not, however, specify the boundary horizon because of the lack of index species. Sample 307-U1318A-12H-CC also includes Miocene taxa (Praeorbulina circularis and Globoquadrina dehiscens) that may have been reworked, and its age was tentatively regarded as Pliocene-Pleistocene because of the occurrence of $G$. inflata and Globorotalia crassaformis. Sample 307U1318A-13H-CC (121.3 mbsf) lacks age-diagnostic species (Fig. F7). In the lowermost two samples (307U1318A-14H-CC and 15H-CC; 128.2 and 139.1 mbsf), the Pliocene-Pleistocene species ( $G$. inflata and G. crassaformis) are absent, and the assemblage is dominated by the Miocene taxa. Their age is 14.816.0 Ma, as determined by the occurrence of Praeorbulina circularis.

The planktonic foraminifer assemblage in lithostratigraphic Unit 1 in Hole U1318A is dominated by cool to temperate taxa Globigerina bulloides and Neogloboquadrina pachyderma (dextral and sinistral). Lithostratigraphic Units 2 and 3 more commonly yield the warmer water taxa G. crassaformis, Globorotalia crassula, G. inflata, Globorotalia scitula, Orbulina universa, and Globigerinoides spp.

\section{Benthic foraminifers}

Sediments from Hole U1318A yield similar assemblages of benthic foraminifers as sediment from the other two sites (Fig. F8). Shallow-water species, such as Elphidium excavatum and Islandiella norcrossi, are more common in lithostratigraphic Unit 1 than in Units 2 and 3. Otherwise, there is no significant difference in assemblage among the three lithostratigraphic units. Species diversity is largest in Unit 3. Species associated with cold seepage, Bulimmina marginata and Bulimmina sp. A, are common throughout Hole U1318A (Fig. F8).

\section{Discussion}

An overview of the biostratigraphy in Holes U1318A and U1318B indicates that the ages of lithostratigraphic Units 1 and 2 are late and early Pleistocene, respectively, although the sediments contain large amounts of reworked Late Cretaceous nannofossils (Fig. F9). The hiatus at 86.7 mbsf in Hole U1318A 
(Fig. F6) defines the boundary between lower Pleistocene and possible Pliocene-Miocene sediment, according to calcareous nannofossils. This hiatus, however, corresponds to the boundary of seismic Units P3 and P2 (Fig. F9) and can not be confirmed in the planktonic foraminifer biostratigraphy (Fig. F6). This inconsistency will be examined by further biostratigraphic investigation.

\section{Paleomagnetism}

Shipboard paleomagnetic measurements were conducted on cores from Holes U1318A, U1318B, and U1318C. Alternating-field demagnetization of natural remanent magnetization (NRM) was conducted up to $20 \mathrm{mT}$ in $5 \mathrm{mT}$ steps on Core 307-U1318A-1H. Based on this demagnetization experiment (Fig. F10), the other sections were demagnetized at 10 and $15 \mathrm{mT}$. NRM and magnetization after two-step demagnetization were measured on archive halves. Discrete samples were taken on the working halves of cores in Holes U1318A and U1318B for subsequent shore-based magnetostratigraphic and rock magnetic studies.

The inclination data are clustered around $\sim 64^{\circ}$ in the uppermost part of Hole U1318A (Fig. F11). Between 58 and $64 \mathrm{mbsf}$, the inclination data decrease to $0^{\circ}$, which is probably a magnetic drilling overprint. Below 86 mbsf, the inclination data become more scattered. In Holes U1318B and U1318C, a similar trend is observed. The inclination data centers at $\sim 66^{\circ}$ but becomes more scattered near 88 mbsf in Hole U1318B and 84 mbsf in Hole U1318C. The inclination data must be interpreted cautiously because some bias and background noise in the cryogenic magnetometer and magnetic overprint gathered during drilling imparts an artificial magnetic inclination pointing downward. This is especially problematic for sediments with low magnetic intensities, such as carbonates.

Declination data could only be corrected by Tensor tool measurements for Cores 307-U1318A-3H through $11 \mathrm{H}, 307-\mathrm{U} 1318 \mathrm{~B}-3 \mathrm{H}$ through $14 \mathrm{H}$, and 307-U1318C-2H through 7H (Fig. F12). Declination data could not be corrected for the other cores because of XCB coring. Below 86 mbsf in Hole U1318A, 88 mbsf in Hole U1318B, and 84 mbsf in Hole $\mathrm{U} 1318 \mathrm{C}$, the declination data become more scattered, similar to the inclination data.

Up to 33 mbsf in Hole U1318A and 35.05 mbsf in Hole U1318B, magnetic intensities are between 0.002 and $0.02 \mathrm{~A} / \mathrm{m}$ (Fig. F13). At $33 \mathrm{mbsf}$ in Hole U1318A and 35.05 mbsf in Hole U1318B, intensities show an increase to $0.03-0.04 \mathrm{~A} / \mathrm{m}$ and fall to $0 \mathrm{~A} / \mathrm{m}$ at 60-62 mbsf. Between 60 and 79 mbsf in Hole U1318A and between 62 and 81.35 mbsf in Hole $\mathrm{U} 1318 \mathrm{~B}$, a doublet in magnetic intensity shows the highest values at Site U1318 (up to $0.07 \mathrm{~A} / \mathrm{m}$ ). Below 87.75 mbsf in Hole U1318A, 87.1 mbsf in Hole U1318B, and 85.35 mbsf in Hole U1318C, intensities decrease to extremely low values of $10^{-5} \mathrm{~A} / \mathrm{m}$. The different zones identified in the intensity correspond well with the lithostratigraphic units (see "Lithostratigraphy"). We see similar trends in magnetic susceptibilities (see "Physical properties"). This suggests that concentration of magnetic minerals, and magnetic mineralogy have the primary effect on the intensities; geomagnetic intensity is secondary.

Artificial magnetic overprints gathered during drilling and limitations in the reliability of the directional data from low-intensity measurements limits correlation to the geomagnetic polarity timescale. Thus, this first magnetostratigraphic interpretation awaits further measurements on discrete samples. Nevertheless, the positive inclinations above 86 mbsf in Hole U1318A, 88 mbsf in Hole U1318B, and 84 mbsf in Hole U1318C can be interpreted as a normal polarity zone corresponding with the Brunhes Chron, which has an age $<0.78 \mathrm{Ma}$. This interval corresponds to lithostratigraphic Unit 1 and thin Unit 2 (see "Lithostratigraphy"). Below the base of Unit 2, inclination and declination data are scattered because of the drop in intensity. The base of lithostratigraphic Unit 2 is a sharp erosive boundary underlain by a shell bed (see "Lithostratigraphy") and corresponds to a large hiatus (see "Biostratigraphy").

\section{Geochemistry and microbiology Geochemistry}

Interstitial water and gas

A total of 31 interstitial water samples were obtained from Site U1318. One interstitial water sample per core was collected from Hole U1318A, except Cores $307-\mathrm{U} 1318 \mathrm{~A}-1 \mathrm{H}, 2 \mathrm{H}$, and $3 \mathrm{H}$, where resolution was increased to two samples per core. One interstitial water sample per core was collected from Hole U1318B, except Cores 307-U1318B-19X and 20X, from which no samples were recovered. Filtered $(0.45 \mu \mathrm{m})$ samples were analyzed for $\mathrm{pH}$, salinity, chlorinity, alkalinity, sulfate $\left(\mathrm{SO}_{4}{ }^{2-}\right)$, chloride $\left(\mathrm{Cl}^{-}\right)$, ammonium $\left(\mathrm{NH}_{4}^{+}\right)$, silica $\left(\mathrm{Si}[\mathrm{OH}]_{4}\right)$, boron $\left(\mathrm{H}_{3} \mathrm{BO}_{3}\right)$, dissolved inorganic carbon (DIC), and major $\left(\mathrm{Mg}^{2+}\right.$ and $\left.\mathrm{Ca}^{2+}\right)$ and minor $\left(\mathrm{Fe}^{2+}, \mathrm{Li}^{+}, \mathrm{Sr}^{2+}\right.$, and $\left.\mathrm{Ba}^{2+}\right)$ elements. The interstitial water data are provided in Table T5. Details of analytical methods are provided in "Geochemistry and microbiology" in the "Methods" chapter. 
Chlorinity (Table T5) shows an increase from $\sim 575$ $\mathrm{mM}$ in the shallowest sample to $589 \mathrm{mM}$ at $\sim 150$ mbsf in Hole U1318A (Fig. F14). In the interval from 150 to 200 mbsf in Hole U1318B, chlorinity decreases downcore to $\sim 580 \mathrm{mM}$. Below this interval and to the base of the hole, chlorinity increases to $\sim 585 \mathrm{mM}$. The downcore trend in chlorinity may reflect a combination of (1) ongoing adjustment of pore water chlorinity to variations in mean ocean salinity that has generally increased over the past few million years in response to increasing continental ice volume (McDuff, 1985), (2) diffusion of chloride from high-chlorinity glacial seawater out of the sediment column (McDuff, 1985), and (3) hydration of silicates.

At Site U1318, 27 samples were collected for safety measurements of methane levels and 25 samples were obtained for analysis of adsorbed methane concentrations (Table T6). Dissolved methane (based on analyses of the safety gas samples) (see "Geochemistry and microbiology" in the "Methods" chapter) remains at or near the detection limit of $0.03 \mu \mathrm{M}$ throughout the extent of the profile at Site U1318, suggesting little to no methane production. Concentrations of adsorbed methane, based on the difference between samples treated with $\mathrm{NaOH}$ and the safety gas samples, were significantly higher throughout the hole (Table T6). Adsorbed methane concentrations were in the range of 0.01 to 0.05 $\mathrm{\mu mol} / \mathrm{g}$ throughout most of the site, although there were some distinct excursions to tenfold or higher concentrations in sediments deeper than 162 mbsf.

In Hole U1318A, the highest measured sulfate concentration is $26 \mathrm{mM}$, close to the seawater value of $28 \mathrm{mM}$ (Fig. F15A). Throughout the extent of the profile, sulfate concentrations never decrease to values $<11 \mathrm{mM}$. The downcore variations with multiple extremes (Fig. F15A) are somewhat enigmatic. A correspondence to lithologic variations, however, suggests a link between lithology, intervals of erosion or nondeposition, and/or sediment accumulation rate. These relationships are discussed in further detail below.

Alkalinity (Fig. F15B) at Site U1318 varies between 5 and $13 \mathrm{mM}$. In the uppermost part of the site, alkalinity increases from $5 \mathrm{mM}$ near the top to $\sim 12 \mathrm{mM}$ at $10 \mathrm{mbsf}$. Values then decrease over the underlying $10 \mathrm{~m}$ to $5 \mathrm{mM}$. Below this interval, alkalinity shows a gradual increase to a value of $13 \mathrm{mM}$ near the base of Hole U1318B. The general increasing trend that characterizes the pore water alkalinity profile below 20 mbsf is overprinted by an excursion toward slightly higher values between 40 and 90 mbsf. The downcore trend suggests that the highest rates of al- kalinity production, generated mostly as bicarbonate ion $\left(\mathrm{HCO}_{3}^{-}\right)$, are within the upper $10 \mathrm{~m}$ of the core, between 40 and 90 mbsf, and at some depth below the base of Hole U1318B. The variations in the alkalinity profile are matched by similar variations in concentrations of DIC (Fig. F15C).

Ammonium in marine pore waters is produced largely through anaerobic reduction of detrital organic matter (Gieskes, 1983). Ammonium concentrations at Site U1318 range between $\sim 400$ and 1700 $\mu \mathrm{M}$, with the highest values found in the upper half $(<120 \mathrm{mbsf})$ of the site. Variations in the ammonium, alkalinity, and DIC profiles (Fig. F15D) mirror the sulfate curve, suggesting that the minor amounts of sulfate reduction observed at Site U1318 led to alkalinity production by anaerobic degradation of organic matter.

Iron concentrations at Site U1318 range from 0 to 68 $\mu \mathrm{M}$ (Fig. F15E), with the higher concentrations occurring in the upper 100 and lower $50 \mathrm{~m}$ of the profile ( $<100$ and $>200$ mbsf, respectively). Variations in the Fe profile are attributed to sulfate reduction and Fe availability for sulfide precipitation. At Site U1318, higher Fe concentrations correspond roughly to depths where dissolved sulfate values decrease slightly, suggesting that reduction of Fe(III)-bearing minerals by sulfide is occurring.

Pore water $\mathrm{Mn}^{2+}$ concentrations (Fig. F15F) remain below $5 \mu \mathrm{M}$ throughout the extent of the profile. Values decrease from $4.6 \mu \mathrm{M}$ in the shallowest sample to a minimum of $0 \mu \mathrm{M}$ at $90-120$ mbsf. Slightly higher $\mathrm{Mn}^{2+}$ concentrations in the shallowest samples imply that the oxidation of organic matter is sufficient to deplete oxygen above the depth of sulfate reduction in the upper $10 \mathrm{~m}$ of the sediment column. The interval from 120 to 200 mbsf is marked by a transient excursion to $2 \mu \mathrm{M}$, which peaks at 165 mbsf. Below 200 mbsf, $\mathrm{Mn}^{2+}$ is absent from the pore fluid.

The $\mathrm{Ba}^{2+}$ profile at Site U1318 is somewhat enigmatic. Although much of the profile is characterized by concentrations $<1 \mu \mathrm{M}$, a few samples above 85 mbsf in Hole U1318A have unusually high concentrations $(6.1 \mu \mathrm{M}$ in Sample 307-U1318A-2H-1, 140$150 \mathrm{~cm} ; 5.7 \mu \mathrm{M}$ in Sample $4 \mathrm{H}-3,140-150 \mathrm{~cm}$; and $4.0 \mu \mathrm{M}$ in Sample 6H-3, 140-150 cm) (Fig. F15G). These high concentrations were confirmed by running duplicate samples on the inductively coupled plasma-atomic emission spectrometer. Given that $\mathrm{Ba}^{2+}$ in pore fluids is controlled mainly by the solubility of barite, which becomes soluble only when sulfate concentrations are $<5 \mu \mathrm{M}$, the higher values observed in the upper half of the profile are not clearly understood. 
Excursions in the profiles of alkalinity, DIC, sulfate, ammonium, $\mathrm{Fe}$, and $\mathrm{Mn}^{2+}$ show a striking correspondence with lithologic variations (Fig. F15), in particular, unconformable surfaces and the contacts between lithostratigraphic units (see "Lithostratigraphy"). In each case, the lithologic boundaries are represented by terminal electron acceptor process successions in the pore water profile, namely $\mathrm{Mn}^{2+}$, followed by $\mathrm{Fe}^{2+}$ and $\mathrm{SO}_{4}{ }^{2-}$. This association suggests that downcore variations in the profiles of sulfate, alkalinity, DIC, ammonium, $\mathrm{Fe}^{2+}$, and $\mathrm{Mn}^{2+}$ record the positions of past sediment/water interfaces, below which an electron acceptor profile developed. The increasingly broad nature of the geochemical excursions with depth is interpreted as reflecting increasing age of the pore water and time available for diffusion.

The base of lithostratigraphic Subunit 1A (33.3 mbsf in Hole U1318A and 35.03 mbsf in Hole U1318B), for example, corresponds to a peak (excursion to higher values) in the sulfate profile and a valley (lower values) in the alkalinity, DIC, and ammonium profiles. Given the sharp decrease in the sulfate profile and increases in alkalinity, DIC, and ammonium profiles within the upper $\sim 10 \mathrm{~m}$ of Hole $1318 \mathrm{~A}$, the underlying transition to higher $\mathrm{SO}_{4}{ }^{2-}$ and lower alkalinity, DIC, and $\mathrm{NH}_{4}{ }^{+}$values implies that the contact between lithostratigraphic Subunits $1 \mathrm{~A}$ and $1 \mathrm{~B}$ records an interval of relatively oxidizing conditions and low organic carbon flux at the seafloor and within in the shallow subsurface. These conditions may have caused a decrease in the rate of sulfate reduction.

The excursion to lower dissolved sulfate values centered between 70 and 80 mbsf in Hole U1318A is matched by shifts to higher values in the alkalinity, DIC, and ammonium profiles (Fig. F15). These excursions correspond roughly to the contact between lithostratigraphic Units 1 and 2 (see "Lithostratigraphy"). This contact is defined by a shift from sandy clays (Unit 1) to dropstone-bearing fine sand and clay underlain by a conglomerate containing probable phosphorite clasts (Unit 2) and marks an unconformity defined on the basis of biostratigraphy (see "Biostratigraphy"). Phosphorite deposition commonly records periods of slow deposition and upwelling that lead to the development of reducing conditions at the seafloor.

In the lower part of Hole U1318B, the contact between lithostratigraphic Subunits 3B and 3C corresponds to shifts in the profiles of sulfate (beginning of a downcore trend toward lower values), ammonium (top of transient excursion to higher values), $\mathrm{Fe}^{2+}$ (shift to higher concentrations), and $\mathrm{Mn}^{2+}$ (shift to lower values) (Fig. F15). This correspondence suggests that these geochemical parameters were influenced by the lithologic change from silty clays (Subunit 3B) to dolomite-bearing silty clays and fine sands (Subunit 3C).

Concentrations of $\mathrm{Ca}^{2+}$ are similar to that of seawater at the top of the pore water profile $(9.8 \mathrm{mM})$ and show an overall increase downcore to $22.7 \mathrm{mM}$ in the deepest sample (Fig. F16A). This general trend is overprinted by two concave-downward excursions. At Hole U1318A, Ca ${ }^{2+}$ values decrease to $5.6 \mathrm{mM}$ within the uppermost $15 \mathrm{~m}$ then increase to $8.1 \mathrm{mM}$ at 31.45 mbsf. Concentrations remain relatively uniform in the interval from 31.45 to 70.57 mbsf and then gradually increase to the base of the profile in Hole U1318B.

Relative to calcium, $\mathrm{Mg}^{2+}$ concentrations (Fig. F16B) remain relatively uniform throughout the extent of the pore water profile $(42.7 \pm 3.3 \mathrm{mM})$. The greatest changes in magnesium occur within the upper $15 \mathrm{~m}$ of Hole U1318A and below 190 mbsf in Hole U1318B.

Dolomitization in lithostratigraphic Subunit 3C (Hole U1318B, 190.3-241.0 mbsf) (see "Lithostratigraphy") may account for shifts to higher $\mathrm{Ca}^{2+}$ and lower $\mathrm{Mg}^{2+}$ pore water concentrations in the lower part of the profile (Fig. F16). The process of dolomitization, which generally involves the replacement of half of the $\mathrm{Ca}^{2+}$ ions in calcite or aragonite with $\mathrm{Mg}^{2+}$, results in removal of $\mathrm{Mg}$ and addition of $\mathrm{Ca}$ to the pore water system.

The silica $\left(\mathrm{Si}[\mathrm{OH}]_{4}\right)$ profile at Site U1318 appears to be influenced by lithologic changes associated with the unconformity surface that marks the base of lithostratigraphic Unit 2 (see "Lithostratigraphy"). Above this surface, silica concentrations are relatively uniform, averaging $251 \pm 45 \mu \mathrm{M}$ (Fig. F17A). Below the unconformity, silica concentrations are relatively high $(928 \pm 76 \mu \mathrm{M})$ and show a slight increase with depth. The observed trend suggests equilibrium control by different siliceous phases above and below the unconformity.

As observed at Site U1316 (see "Geochemistry and microbiology" in the "Site U1316" chapter), B, Sr' and $\mathrm{Li}^{+}$have similar profiles (Fig. F17B-F17D). The concentrations of these elements remain uniform in the upper $70 \mathrm{~m}$ of the sediment column before smoothly increasing in a concave-upward fashion to maxima at 236.35 mbsf in Hole U1318B, the depth of the deepest sample collected. The decrease in the slope of the profiles and higher concentrations of $\mathrm{B}$, $\mathrm{Sr}^{2+}$, and $\mathrm{Li}^{+}$with depth may reflect a combination of high rates of sediment accumulation, decreasing diffusivity downcore, and accelerated rates of silicate 
(Li and B) and carbonate ( $\mathrm{Sr}$ ) diagenesis below the deepest sample obtained.

\section{Sediments}

Carbonate determinations by coulometry were made on 53 samples from Site U1318 (Table T7). Samples were chosen to coincide with those used to determine dry bulk density (see "Physical properties"). Results provide a measure of the carbonate content within different units and allow assessment of the influence of carbonate content on parameters such as color reflectance. Carbonate concentrations, measured as dry weight percent $\mathrm{CaCO}_{3}$, show less variation ( 10-50 wt\%) than at Sites U1316 and U1317 (Fig. F18). There appears to be a relationship between carbonate content and changes in lithology. Carbonate concentrations are relatively low and uniform (16 $\pm 3 \mathrm{wt} \%)$ throughout the upper part of Hole U1318A (0 to $\sim 86 \mathrm{mbsf}$ ) over the depths that comprise lithostratigraphic Units 1 and 2 (see "Lithostratigraphy"). Below the base of lithostratigraphic Unit 2 and to a depth of 160 mbsf in Hole U1318B, the carbonate profile shows a transient excursion to concentrations as high as $50 \mathrm{wt} \%$. In the lower part of the profile ( $>160 \mathrm{mbsf}), \mathrm{CaCO}_{3}$ concentrations tend to increase downcore, reaching a value of $\sim 35$ wt $\%$ in the deepest sample obtained. Within this interval, two outlying data points (Samples 307U1318B-24X-1, 15-16 cm, and 25X-1, 7-8 cm) reach higher values of 70 and $72 \mathrm{wt} \%$, respectively. These higher concentrations likely correspond to lithified dolomite-bearing layers discussed in "Lithostratigraphy."

\section{Microbiology}

\section{Whole-round core and catwalk sampling}

Whole-round cores (WRCs) were taken from Holes U1318A and U1318B for shore-based work. A 2 or $1.5 \mathrm{~m}$ section from each core was selected on the catwalk. After removal of the interstitial water sample together with a variety of small syringe samples, the remainder of the section was taken directly from the catwalk to cold storage at $10^{\circ} \mathrm{C}$, where WRC sections were cut and packed. Appropriately packed samples were stored at either $+4^{\circ}$ or $-80^{\circ} \mathrm{C}$. The distribution and packing/storing requirements of all samples and their sample codes are given in Figures F19 and F20. A total of $410 \mathrm{WRC} /$ syringe samples were obtained.

\section{Total prokaryote enumeration}

Samples of $1 \mathrm{~cm}^{3}$ plugs for total prokaryote enumeration were taken during core processing on the catwalk from Holes U1318A (14 samples between the near surface and $135.55 \mathrm{mbsf}$ ) and U1318B (11 sam- ples between 151.95 and $236.35 \mathrm{mbsf}$ ). All the samples in Hole U1318B were stored for later shorebased processing.

Prokaryotes were present in all samples studied, to a depth of 135.5 mbsf (Fig. F21). Maximum numbers observed were $2.7 \times 10^{7}$ cells $/ \mathrm{cm}^{3}$ in the shallowest sample at 4.85 mbsf (Sample 307-U1318A-1H-3, $185-190 \mathrm{~cm}$ ) and the smallest population was $1.42 \times$ $10^{6}$ cells $/ \mathrm{cm}^{3}$ in the deepest sample at $135.5 \mathrm{mbsf}$ (Sample 15H-2, 130-135 cm), a 19-fold decrease over $130 \mathrm{~m}$. The detection limit was estimated at $2 \times 10^{5}$ cells $/ \mathrm{cm}^{3}$, based on calculations of a single membrane filter, and for each sample duplicate filters were used to provide a measure of variability. Where a zero count occurred, the prokaryote population was estimated by combining the data from both membranes and treating it as one subsample. This provides the only possible estimate of the population size in such samples, but does not allow any measure of variability.

The overall depth profile of cell numbers per cubic centimeter initially follows a trend observed at other Ocean Drilling Program sites (Parkes et al., 2000). This trend was accompanied by a significant decrease in sulfate concentrations in the upper $15 \mathrm{~m}$ (26.57-10.36 mM) indicating active sulfate reduction. From approximately the base of lithostratigraphic Subunit 1A (33.3 mbsf) (see "Lithostratigraphy"), cell numbers remain almost constant to 70.47 mbsf (Sample 307-U1318A-8H-3, 130-135 cm). Given that the prediction line is constantly decreasing, this suggests active population maintenance. This is supported by high proportions of dividing cells and a concavity in the sulfate profile over this depth range indicating continuing, although less active, sulfate reduction. At $81.7 \mathrm{mbsf}$, there is a significant erosion boundary separating sediments of substantially different ages (see "Biostratigraphy"). Across this boundary there is a factor of 3 decrease in prokaryote numbers from $1.24 \times 10^{7} \mathrm{cells} / \mathrm{cm}^{3}$ at 70.47 mbsf (Sample 307-U1318A-8H-3, 130-135 cm) to $3.96 \times 10^{6}$ cells $/ \mathrm{cm}^{3}$ at $89.5 \mathrm{mbsf}$ (Sample $10 \mathrm{H}-3$, $130-135 \mathrm{~cm}$ ). Below $89.5 \mathrm{mbsf}$, prokaryote populations decrease logarithmically and at a much greater rate than the prediction line. Within this depth range, few or zero dividing cells were observed, indicating that populations were in significant decline. The fact that this was occurring despite increasing sulfate concentrations between 80.5 and $135.5 \mathrm{mbsf}$ (11.36-16.09 mM) suggests that lack of prokaryote population growth was because of low bioavailable carbon and that these ancient sediments, between 80.5 and 135.5 mbsf, lack an organic carbon substrate for metabolism. Total organic carbon will be determined as part of the shore-based work. Meth- 
ane is often a significant carbon source for deep prokaryotes, but dissolved methane concentrations never rose above $\sim 0.16 \mu \mathrm{M}$ at Site U1318. Both the geochemical data and prokaryote profile suggest that neither methanogenesis nor methane oxidation are occurring at this site.

\section{Contamination tests}

\section{Perfluorocarbon tracer}

PFT was added continuously to the drilling fluid during coring of Hole U1318A to evaluate the penetration depth of the drill mud into the core. Drill mud samples were investigated to confirm the presence of PFT in the drill mud (Table T8). Air samples from the catwalk and the laboratory and several blanks were processed on the gas chromatograph system to exclude background contamination of PFT during analysis (Table T8).

Hole U1318A was cored using the APC. All inner core subsamples were negative for PFT. Although the hydraulic piston corer technique should theoretically reduce the contact of the drill fluid with the core material, PFT was detected on the outer surface of four cores (Cores 307-U1318A-9H, 11H, 12H, and $13 \mathrm{H})$.

The first 14 cores in Hole U1318B were drilled with the APC followed by XCB coring down to the base. In Hole U1318B, PFT was not delivered to the drill mud before coring of Core 307-U1318B-19X because initially there was no intention to take samples from Hole U1318B. Thus, there is no contamination control for the first samples of this core taken from Sections 307-U1318B-17X-3 and 18X-3. All other deeper core sections selected for microbiology (MBIO) and geochemistry subsampling tested negative for PFT (Table T8).

\section{Particulate tracer}

Fluorescent microspheres were deployed in all cores from which MBIO samples were taken in Holes U1318A and U1318B. Subcores of $5 \mathrm{~cm}^{3}$ were taken from the bottom cut end of each MBIO section adjacent to the interstitial water WRC. Microspheres were detected in three samples from Hole U1318A and two samples from Hole U1318B. These data included the highest number of microspheres detected in contamination tests at all three sites of this expedition (2425 microspheres/ $\mathrm{cm}^{3}$ in Section 307U1318A-3H-3); however, this is still small compared to the original microsphere suspension at 7,000,000 microspheres $/ \mathrm{mL}$. The number of microspheres detected in Sample 307-U1318A-3H-3, 23.55-23.6 cm (2425 microspheres $/ \mathrm{cm}^{3}$ ) is still only equivalent to the estimated minimum penetration of $0.35 \mathrm{~nL}$ of drill fluid $/ \mathrm{cm}^{3}$, or $0.35 \mathrm{ppm}$. Given this is the only core in the upper $100 \mathrm{~m}$ that exhibited contamination, it is likely to be a single problem core rather than a general coring problem. Contamination toward the base of Hole U1318A is not surprising as core material is usually more prone to cracking at the extremes of APC coring capability, as in this case. $\mathrm{XCB}$ coring is generally more prone to contamination than APC, although that did not appear to be so here with only two instances of contamination detected in Hole U1318B.

\section{Physical properties}

The physical properties measured on the cores of Site U1318 include magnetic susceptibility measured with the "Fast Track" multisensor core logger (MSCL) and multisensor track (MST), gamma ray attenuation (GRA) density, natural gamma radiation (NGR), $P$ wave velocity measured continuously with the MST $P$-wave logger (PWL) and at discrete positions on the split cores with the $P$-wave sensor (PWS), moisture and density (MAD), shear strength, and thermal conductivity. PWL measurements were unreliable with $\mathrm{XCB}$ drilling because the gap between sediment and core liner blocks the acoustic signal and the piecewise recovery ("biscuits") gives large variations in the recovered sediment column. Shear strength measurements were only carried out on core sections from 0 to 90 mbsf. Below $90 \mathrm{mbsf}$, the sediment became too indurated.

Recovery at Site U1318 was very good, so nearly continuous records of the parameters were acquired. The resulting curves, expressed in meters composite depth (mcd) and constructed after splicing the data from the three holes at this site, are presented in Figure F22.

\section{Magnetic susceptibility}

Overall, magnetic susceptibility ranges from $3 \times 10^{-5}$ to $160 \times 10^{-5}$ SI units. The trend of the magnetic susceptibility depth curve shows a gradual increase in the upper $\sim 38$ mcd of the cores to a local maximum of $130 \times 10^{-5}$ SI units at $\sim 38 \mathrm{mcd}$, although several intervals with high-amplitude oscillations occur. For example, significant breaks in the overall trend are observed at $\sim 20$ and $35 \mathrm{mcd}$, with drops of $\sim 25 \times 10^{-5}$ and $30 \times 10^{-5}$ SI units, respectively. From a depth of 38 mcd downhole, the magnetic susceptibility gradually decreases until $\sim 62$ mcd with a local minimum of $34 \times 10^{-5}$ SI units; however, over this interval values show more short-period oscillations with higher amplitudes. From 62 to $80 \mathrm{mcd}$, the magnetic susceptibility increases rapidly with high-amplitude oscillations $>90 \times 10^{-5}$ SI units. At $\sim 82 \mathrm{mcd}$, the mag- 
netic susceptibility drops drastically to $\sim 20 \times 10^{-5}$ SI units followed by a limited increase and several sharp spikes, the last one marking a clear boundary at 92 mcd. Below this boundary, the magnetic susceptibility remains very low, largely varying between $3 \times 10^{-5}$ and $12 \times 10^{-5}$ SI units.

\section{Natural gamma radiation}

The NGR depth curve at Site U1318 shows a gradual increase in the uppermost $22 \mathrm{mcd}$, characterized by regular and high-amplitude oscillations. This overall trend stays constant until $\sim 82 \mathrm{mcd}$, where NGR decreases from $\sim 50$ to $20 \mathrm{cps}$ at $83 \mathrm{mcd}$. The interval from 83 to $92 \mathrm{mcd}$ is characterized by highamplitude oscillations in a very short range with remarkably high peak values $>100$ cps at $\sim 92$ mcd. Below this depth, the curve follows a smooth increase until $\sim 192 \mathrm{mcd}$. Values in the interval below 192 mcd stay, in general, lower than in the upper part, ranging from 15 to $50 \mathrm{cps}$. Some-well defined largescale cycles are present (e.g., 168-191 and 191-240 mcd) in the lower part of the curve.

\section{Gamma ray attenuation density, bulk density, and porosity}

The bulk density measurements (i.e., GRA-corrected density and MAD measurements) display parallel trends. GRA densities deduced from the MST are corrected in the unconsolidated section of the cores according to the equation described in "Physical properties" in the "Methods" chapter. The density increases in the upper $15 \mathrm{mcd}$ of the site from 1.7 to $2.1 \mathrm{~g} / \mathrm{cm}^{3}$. From there the values decrease sharply to $1.8 \mathrm{~g} / \mathrm{cm}^{3}$, remain low until $21 \mathrm{mcd}$, and increase again to a maximum of $2.2 \mathrm{~g} / \mathrm{cm}^{3}$ at $29 \mathrm{mcd}$. This is followed by an interval of fairly constant density, which finally reaches a local peak at $54 \mathrm{mcd}$, followed by a minimum of $\sim 1.9 \mathrm{~g} / \mathrm{cm}^{3}$ at $60 \mathrm{mcd}$. From this point, GRA density becomes more irregular with an overall increasing trend until 92 mcd. This depth represents a major break in the density depth curve with a reduction in density from $\sim 2.2$ to $1.9 \mathrm{~g} / \mathrm{cm}^{3}$. Between 92 and $132 \mathrm{mcd}$, the density stays relatively constant with low-amplitude oscillations; however, some broad cycles can be distinguished. Another sharp reduction in density can be observed at 132 mcd, and the depth curve evolves in a sawtooth pattern. From $192 \mathrm{mcd}$, the amplitudes and frequencies of these oscillations become more irregular, whereas the average density value increases slightly.

\section{Shear strength}

Shear strength, measured with the Torvane apparatus, shows four distinctive trends in the upper $92 \mathrm{~m}$ of Hole U1318A:
1. Shear strength increases from $\sim 0$ to $\sim 6 \times 10^{3} \mathrm{~kg} /$ $\mathrm{m}^{2}$ in the upper $32 \mathrm{mcd}$.

2. After a drop to $4 \times 10^{3} \mathrm{~kg} / \mathrm{m}^{2}$, values increase between 38 and $58 \mathrm{mcd}$, reaching a local maximum of $7.5 \times 10^{3} \mathrm{~kg} / \mathrm{m}^{2}$. This interval concludes with a drop in values from $7.5 \times 10^{3}$ to $5.5 \times 10^{3}$ $\mathrm{kg} / \mathrm{m}^{2}$.

3. This drop is followed by a fairly steep increase to $9 \times 10^{3} \mathrm{~kg} / \mathrm{m}^{2}$ at $\sim 72 \mathrm{mcd}$ and remains constant downhole.

4. The last interval measured, from 82 to $92 \mathrm{mcd}$, shows an irregular pattern with larger amplitudes in the oscillations and some gaps in the data.

\section{$P$-wave velocity}

PWL data were consistent with PWS data in the uppermost 130 mcd. Deeper than 130 mcd, small gaps are evident in the curve and the data generally become sparser. Overall, sonic velocity increases irregularly in the upper $15 \mathrm{mcd}$, with local peaks at 2, 5, and $7 \mathrm{mcd}$. Between 15 and $22 \mathrm{mcd}$, sound velocities show a pattern comparable to GRA and bulk density measurements, culminating in a low at $21 \mathrm{mcd}$. This is followed by a sharp increase to $\sim 1630 \mathrm{~m} / \mathrm{s}$ at $\sim 26$ mcd. A zone of slight increase in the values with some small cycles in between occurs until $55 \mathrm{mcd}$, where it reaches a local maximum of $\sim 1700 \mathrm{~m} / \mathrm{s}$. Between 55 and $91 \mathrm{mcd}$, the curve drops to $\sim 1560 \mathrm{~m} / \mathrm{s}$ at $61 \mathrm{mcd}$ and begins an increasing trend with higher amplitude cycles until a peak of $1720 \mathrm{~m} / \mathrm{s}$ at $91 \mathrm{mcd}$, where there is a clear boundary in the GRA and NGR data sets. This is followed by a long interval, from 92 to $122 \mathrm{mcd}$, characterized by a moderate increase in sound velocity and low-amplitude $(<100 \mathrm{~m} / \mathrm{s})$ cycles with highs between $\sim 100$ and 112 mcd, which are very comparable to the trends observed in the GRA density curve. Deeper than 130 mcd, gaps in the PWL data become more evident; however, a decreasing trend can be discerned in the PWS curve until $\sim 186 \mathrm{mcd}$, with a low of $1560 \mathrm{~m} / \mathrm{s}$. Below $186 \mathrm{mcd}$, sound velocities increase irregularly in several cycles to reach a maximum of $1700 \mathrm{~m} / \mathrm{s}$ at 211 mcd and below.

\section{Thermal conductivity and in situ temperature measurements}

The deployment of the advanced piston corer temperature tool provided an insight into the subsurface temperature distribution. Four discrete temperature measurements in Hole U1318A were taken at 28.2, 56.7, 85.2, and 113.7 mbsf (Fig. F23). The data show a temperature gradient of $46^{\circ} \mathrm{C} / \mathrm{km}$, which is a normal value for passive continental margins. 


\section{Interpretation}

Based on the overall trends of the physical properties described above, a set of physical property (PP) units can be defined that correspond to major lithologic units (Fig. F22).

Unit PP1 comprises the upper 16 mcd and is characterized by increasing $P$-wave velocity and density. Magnetic susceptibility and NGR also increase gradually. A sharp drop in density and $P$-wave velocity, a minimum in NGR, and a change in character of the magnetic susceptibility signal (more high-amplitude excursions) mark the lower boundary. The interval is part of lithostratigraphic Subunit 1A and consists of silty clays with a coarser layer toward its base. It has the same characteristics as Unit PP1 in Hole U1316A. In the seismic profile, it corresponds to a package of chaotic reflections of moderate to high amplitude.

Unit PP2 (16-24 mcd) corresponds to a low-density and $P$-wave velocity interval and an increase in the amount of high-amplitude variability in magnetic susceptibility. NGR values slightly increase. The unit shows the same characteristics as Unit PP2 at Site U1316 and also consists of clayey materials with faint laminations. Again, this unit falls within lithostratigraphic Subunit 1A. The seismic expression of this unit is relatively low in amplitude compared to the surrounding seismic facies. The lower boundary is erosive and high in amplitude.

Unit PP3 comprises the interval between the sharp increase in density and velocity at 24 mcd and a significant increase in magnetic susceptibility at 60 mcd. The unit itself is characterized by minimal variations in the trends of most physical properties, although shear strength and magnetic susceptibility show local maxima at 33 mcd that correspond to a $24 \mathrm{~cm}$ thick graded layer of fine sand or silt on an erosive boundary forming the base of lithostratigraphic Subunit 1A. The lower part of Unit PP3 corresponds to lithostratigraphic Subunit 1B, which is characterized by dark silty clay horizons with strong lamination. Acoustically, Unit PP3 is characterized by parallel high-amplitude reflectors and, in the lower part, moderate- to low-amplitude reflectors.

The significant increase in magnetic susceptibility, together with a change in $P$-wave velocity (PWS) trend and a local minimum in shear strength at 62 mcd, marks the upper boundary of Unit PP4, which extends to $84 \mathrm{mcd}$. Unit PP4 overlaps lithostratigraphic Subunit 1C, which contains abundant laminations and slightly coarser material than the subunits above and may correspond to Unit PP4 at Site U1316. At Site U1318, Unit PP4 corresponds in the seismic profile to a high-frequency, high-amplitude facies of parallel reflectors. The frequency of the re- flectors is higher than in the overlying facies. Toward the lower boundary of Unit PP4, the reflectors are lower in amplitude.

Unit PP5 (84-92 mcd) is marked by a sharp reduction in magnetic susceptibility, NGR, and shear strength in the uppermost sections and a gradual increase in these values toward the base, although with some sharp spikes. Unit PP5 corresponds to lithostratigraphic Unit 2 and contains interbedded sands and silty clays with abundant shell fragments and pebble-sized clasts. The thickest sand layers occur toward the uppermost sections, where the magnetic susceptibility and NGR are minimal. The lower boundary is formed by a $5-10 \mathrm{~cm}$ thick shell bed identified as a major hiatus in the biostratigraphy and causing a strong magnetic susceptibility, NGR, $P$-wave velocity, and GRA density signal. These physical properties of the sediment create a highamplitude reflector in the seismic profiles, and this erosive reflector has been tentatively identified as the mound base reflector. Unit PP5 is seismically characterized by high-amplitude reflectors.

Low magnetic susceptibility and fairly constant $P$ wave velocity and density values with low-amplitude broad cycles are the main characteristics of Unit PP6 (92-132 mcd). $P$-wave velocity and density have a remarkable parallel pattern. Unit PP6 corresponds to lithostratigraphic Subunit 3A, comprising greenish gray silty clays and silts and coinciding with moderate- to high-amplitude parallel reflectors. The lowermost reflector bounding Unit PP6 is a highamplitude reflector marking an erosive boundary.

Unit PP7 is located between 132 and 192 mcd, with the lower boundary marked by a local maximum in NGR followed by a reduction in the values of NGR and an increase in $P$-wave velocity. Magnetic susceptibility values stay very low in this unit, although slightly higher than in Unit PP6, whereas $P$-wave velocities are lower than in the unit above. The pattern of GRA density in Unit PP7 shows more sawtooth cycles of higher frequency than in Unit PP6, while the overall value is lower. The lithostratigraphic description mentions Subunit 3B, consisting of homogeneous silty clays bound by sandier intervals in the uppermost and lowermost sections. On the seismic profiles, the Unit PP7 shows a fairly low amplitude homogeneous facies with a couple of highamplitude reflectors that coincide with the more sandy layers.

The lowermost Unit PP8 comprises the interval below 192 mcd. It shows lower NGR values, an increase in $P$-wave velocities (including some extreme values reaching $>3000 \mathrm{~m} / \mathrm{s}$ ), and a slight increase in density in combination with increased amplitudes of highfrequency variations. The high acoustic velocities 
correspond to lithified layers, whereas the unit itself is identified in the lithostratigraphy as Subunit 3C, consisting mainly of silty clay and fine sands. Unit PP8 coincides with high-amplitude, high-frequency parallel reflectors and corresponds to the sigmoidal unit in Hole U1316A.

\section{Relationship between physical properties}

Statistical analysis and correlation tests were performed on the different numerical data sets in order to evaluate the quality of the data, make direct comparisons between different laboratory equipment, and draw potential relationships amongst the physical properties parameters. The statistical data analysis, including normality tests and confidence intervals for each individual core, assisted in the identification of possible outliers. These data were filtered out before further processing. A full set of associated graphs was utilized to aid in the identification of the most important physical parameters causing the seismic reflectors. Figure F24 shows a matrix plot of the correlation between the physical parameters measured in the cores.

Measurements taken for $P$-wave velocity using the PWL (MST) and PWS (split core) were compared in their mean, median, and distribution patterns to check for consistency. Both data sets have a very similar range in velocity values; however, a slight shift in the PWS measurements of approximately $-30 \mathrm{~m} / \mathrm{s}$ was noted. $P$-wave velocity on split cores is compared with NGR (influenced by the clay content), GRA density, porosity, shear strength, and magnetic susceptibility. There is a moderate correlation between sound velocity and density measurements in Units PP1-PP5 (Cores 1-10).

There is a remarkably good correlation between magnetic susceptibility and NGR throughout Hole U1318A, which is particularly high in Unit PP6 (Pearson's correlation coefficient $[\mathrm{PCC}]=>0.8$ ). Magnetic susceptibility also correlates fairly well with shear strength measurements taken over the interval between 0 and 92 mcd (PCC $=\sim 0.75)$, except from 50 to 66 mcd (Cores 6 and 7).

\section{Stratigraphic correlation}

Stratigraphic correlation at Site U1318 was carried out with the help of the Splicer software, as described in "Physical properties" in the "Methods" chapter. An mcd scale was constructed from the physical property data of Holes U1318A, U1318B, and U1318C (Tables T9, T10) as well as a spliced depth curve for most of the parameters at this site (Fig. F22). The main physical properties used to construct the mcd scale were magnetic susceptibility,
GRA density, and NGR. Information about biostratigraphy and lithologic contacts also aided in the construction of the mcd scale and spliced records. Drilling was continued below 160 mcd only in Hole U1318B; therefore, the spliced data below that level are fully based on this hole (Table T10). As the recovery was excellent, however, a nearly continuous depth curve could be constructed for the different physical property parameters. In general, the core expansion at Site U1318, estimated from the extension of the mcd scale versus the mbsf scale, is $\sim 3.5 \%$, which is fairly low.

\section{Downhole measurements}

\section{Logging operations}

The triple combo and FMS-sonic tool strings (Fig. F8 in the "Methods" chapter) were planned for Hole U1318B. After completion of the APC and XCB drilling operation (bit size $=117 / 16$ inches) at $242 \mathrm{mbsf}$, the hole was displaced with $102 \mathrm{bbl}$ of $8.9 \mathrm{ppg}$ sepiolite mud and the pipe set at 70 mbsf in preparation for logging. A summary of the logging operation in Hole U1318B is provided in Figure F25 and a breakdown of the chronology of logging operation is given in Table T11, including some details of the tools used. The tool rig-up was begun on 10 May at $1030 \mathrm{~h}$ and rig-down completed by 10 May 2005 at $2100 \mathrm{~h}$. The triple combo tool string was run to the bottom of the hole ( $242 \mathrm{mbsf}$ ) and logging began at $1030 \mathrm{~h}$ on May 10. The caliper readings from the triple combo tool string suggested that the hole was in very good condition for logging. Difficulties in starting the minitron (neutron source), necessary to evaluate the porosity (APLC) of the formation, suggested a malfunction, but the other tools collected goodquality data. The FMS-sonic tool string was rigged up and run to the bottom of the hole, and two passes were successfully acquired. Logging operations were completed by $2100 \mathrm{~h}$ on 10 May. The heave conditions were excellent, typically $<1 \mathrm{~m}$ throughout the logging operation. Consequently, the wireline heave compensator experienced no problems during this operation.

\section{Data quality}

The triple combo tool string caliper indicated that the hole conditions were very good in the entire open interval (70-242 mbsf) (Fig. F26A) with values smaller than 12 inches. Vertical acceleration $\left(\mathrm{A}_{\mathrm{z}}\right)$ of the FMS-sonic tool string, which integrates the effects of heave, sidewall contact, and wireline stretch on the tool string, indicated that hole conditions and stick-slip of the tool remained at low levels until 
the cable head entered the BHA (Fig. F26B). The orientation of the reference pad of the two passes of the FMS images (Fig. F26E, F26F) shows a very slow and progressive rotation. The two passes followed exactly the same path (Fig. F26G) in the entire open section of the hole (70-242 mbsf) and did not improve the coverage of the borehole. The FMS images are of good quality except for slight degradation of the images from two worn pads. A very high frequency alternation between high and low resistivity is observed in most of the open hole, but mainly in the lower part of the borehole. Some portion of this alternation, especially in the lower section (below 190 mbsf), may be interpreted as drilling marks, but generally its origin is unknown as high-frequency changes in resistivity are not expected from the homogeneous sediments of this part of the hole. It might be an artifact. The Accelerator Porosity Sonde experienced some trouble downhole, and the porosity $\log$ must be interpreted with caution. The quality of the sonic $\log$ is discussed in detail in "Discussion."

The original logs were depth-shifted to the seafloor, based on the step in gamma radiation in the triple combo logs (Fig. F27A). The seafloor depth differs by $<2 \mathrm{~m}$ from the seafloor depth determined from the mudline. Data from the triple combo tool string served as reference by which the features in the equivalent logs of subsequent FMS-sonic tool string runs were matched (Fig. F27B, F27C).

\section{Logging stratigraphy}

The logged section and logging units are characterized by (1) clear shifts in total spectral gamma radiation (HSGR) (Fig. F28A) and bulk density (RHOM) (Fig. F28D) and (2) the impulsive character of the resistivity (Fig. F28C) and acoustic velocity $\left(V_{\mathrm{p}}\right)$ (Fig. F28F) logs. Four logging units were defined (Fig. F28G).

\section{Logging Unit 1: base of pipe (70 mbsf)-81 mbsf}

Logging Unit 1 is characterized by (1) a high level of gamma radiation ( 60 gAPI), (2) a downhole decrease in porosity, and (3) the progressive increase of the photoelectric effect factor (PEF) (from 1.25 to $\left.3 \mathrm{~b} / \mathrm{e}^{-}\right)$. The base of logging Unit 1 is, thus, marked by low porosity and corresponds to lithostratigraphic Unit 1 (see "Lithostratigraphy").

\section{Logging Unit 2: 81-87 mbsf}

Logging Unit 2 is characterized by a major peak in gamma radiation (>120 gAPI), principally associated with an enrichment in uranium (to $16 \mathrm{ppm}$ ). This logging unit is also marked by a subtle change in re- sistivity and slight increase in density. The average velocity of this interval is $\sim 1650 \mathrm{~m} / \mathrm{s}$. Logging Unit 2 corresponds to a lithified sandstone including a bivalve bed (see "Lithostratigraphy").

\section{Logging Unit 3: 87-188 mbsf}

Logging Unit 3 is characterized by a regular cyclicity of gamma radiation with a slight increase with depth mainly associated to the potassium and thorium contribution of natural radioactivity. Electrical resistivity is low and shows only small-amplitude variations in this unit. Density and PEF logs anticorrelate with gamma radiation, suggesting some variation in carbonate and clay content with depth; low gamma radiation and high PEF can be interpreted to be more carbonate rich and high gamma radiation and low PEF to be more clay rich. The background velocity is $\sim 1600 \mathrm{~m} / \mathrm{s}$. The unit is characterized by distinct peaks in acoustic velocity (up to $2000 \mathrm{~m} / \mathrm{s}$ ) and corresponds to siltstone of lithostratigraphic Unit 3 (see "Lithostratigraphy").

\section{Logging Unit 4: 188 mbsf-bottom of the logged section (242 mbsf)}

Logging Unit 4 is characterized by the lowest porosity recorded in the open hole. This unit is also marked by a decrease in gamma radiation (from 60 to $50 \mathrm{gAPI}$ ). This unit presents localized peaks in electrical resistivity concomitant with an increase in density and thus a decrease in porosity. The average acoustic velocity of this logging unit is $>1850 \mathrm{~m} / \mathrm{s}$ with peaks of $\sim 2200 \mathrm{~m} / \mathrm{s}$. Logging Unit 4 corresponds to the lower part of lithostratigraphic Unit 3 (see "Lithostratigraphy").

\section{Discussion}

When in situ velocity of the formation is close to the velocity of the drilling mud $(\sim 1600 \mathrm{~m} / \mathrm{s})$, the $P$-wave labeling algorithm in the Schlumberger software has initial difficulty in identifying the $P$-wave of the formation measured by the Dipole Sonic Imager (Figs. F28F, F29). The two passes of the sonic logs have been improved by reprocessing (Fig. F28F), but some errors in the semiautomatic picking of the $P$-wave persist (Fig. F29).

Comparison between continuous and in situ logs with the whole-core MST records (gamma radiation, density, and velocity) and discrete sample MAD data provides the basis for depth-matching the corederived mcd scale to a logging equivalent depth and correction of physical properties measured on expanded cores (Fig. F30).

The microresitivity (FMS) (vertical resolution $=<1$ $\mathrm{cm}$ ) images can finely resolve the high-frequency cy- 
cles seen, for example, in natural gamma radiation data of logging Units 3 and 4 (87-242 mbsf).

\section{References}

Gieskes, J.M., 1983. The chemistry of interstitial waters of deep-sea sediments: interpretation of deep-sea drilling data. In Riley, J.P., and Chester, R. (Eds.), Chemical Oceanography (Vol. 8): London (Academic), 221-269.

Jenkins, D.G., 1985. Southern midlatitude Paleocene to Holocene planktic foraminifera. In Bolli, H.M., Saunders, J.B., and PerchNielsen, K. (Eds.), Plankton Stratigraphy: Cambridge (Cambridge Univ. Press), 263-282.

Jenkins, D.G., 1993. Cenozoic Southern mid- and high-latitude biostratigraphy and chronostratigraphy based on planktonic foraminifera. In Kennett, J.P., and Warnke,
D.A. (Eds.), The Antarctic Paleoenvironment: A Perspective on Global Change. Antarct. Res. Ser., 60:125-144.

McDuff, R.E., 1985. The chemistry of interstitial waters, Deep Sea Drilling Project Leg 86. In Heath, G.R., Burckle, L.H., et al., Init. Repts. DSDP, 86: Washington (U.S. Govt. Printing Office), 675-687.

Parkes, R.J., Cragg, B.A., and Wellsbury, P., 2000. Recent studies on bacterial populations and processes in marine sediments: a review. Hydrogeol. Rev., 8:11-28.

Van Rooij, D., De Mol, B., Huvenne, V., Ivanov, M., and Henriet, J.-P., 2003. Seismic evidence of current-controlled sedimentation in the Belgica mound province, upper Porcupine slope, SW of Ireland. Mar. Geol., 195(14):31-53.

Publication: 14 October 2006

MS 307-105 
Figure F1. Location of Site U1318.

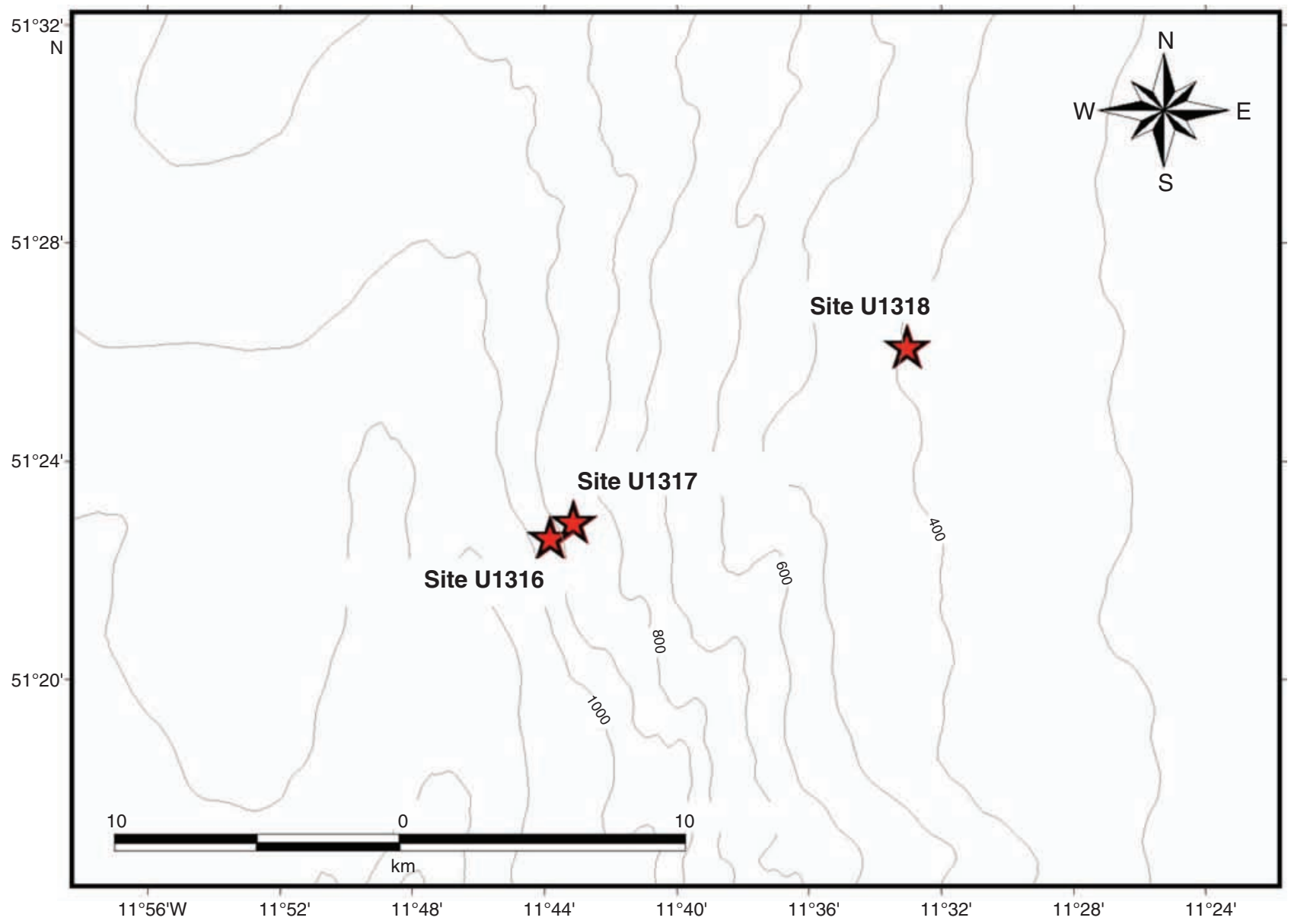




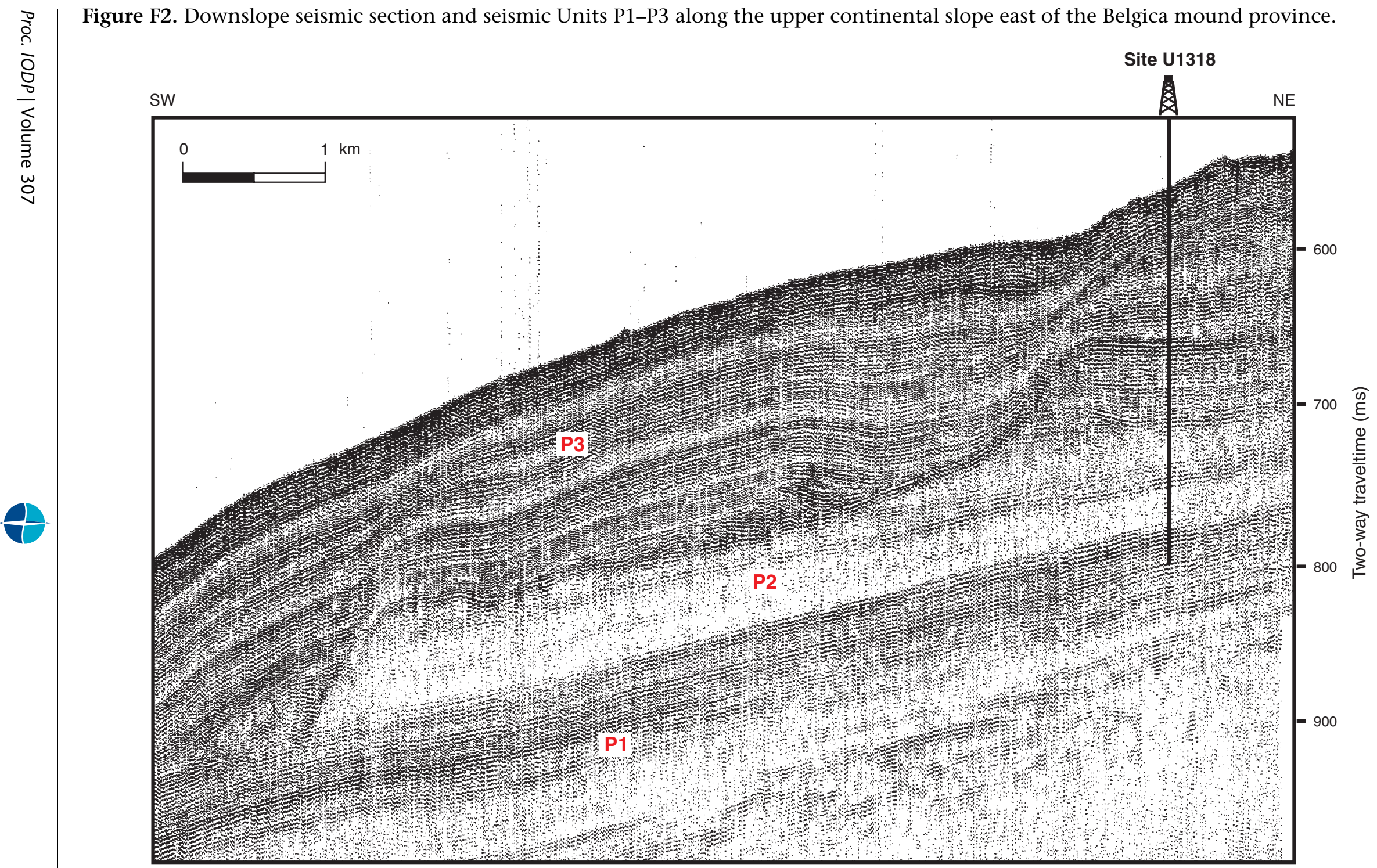


Figure F3. Combined lithologic column of Holes U1318A, U1318B, and U1318C. Each subunit of lithostratigraphic Unit 1 corresponds to a change in magnetic susceptibility. Subunits of Unit 3 are differentiated by changes in carbonate content.

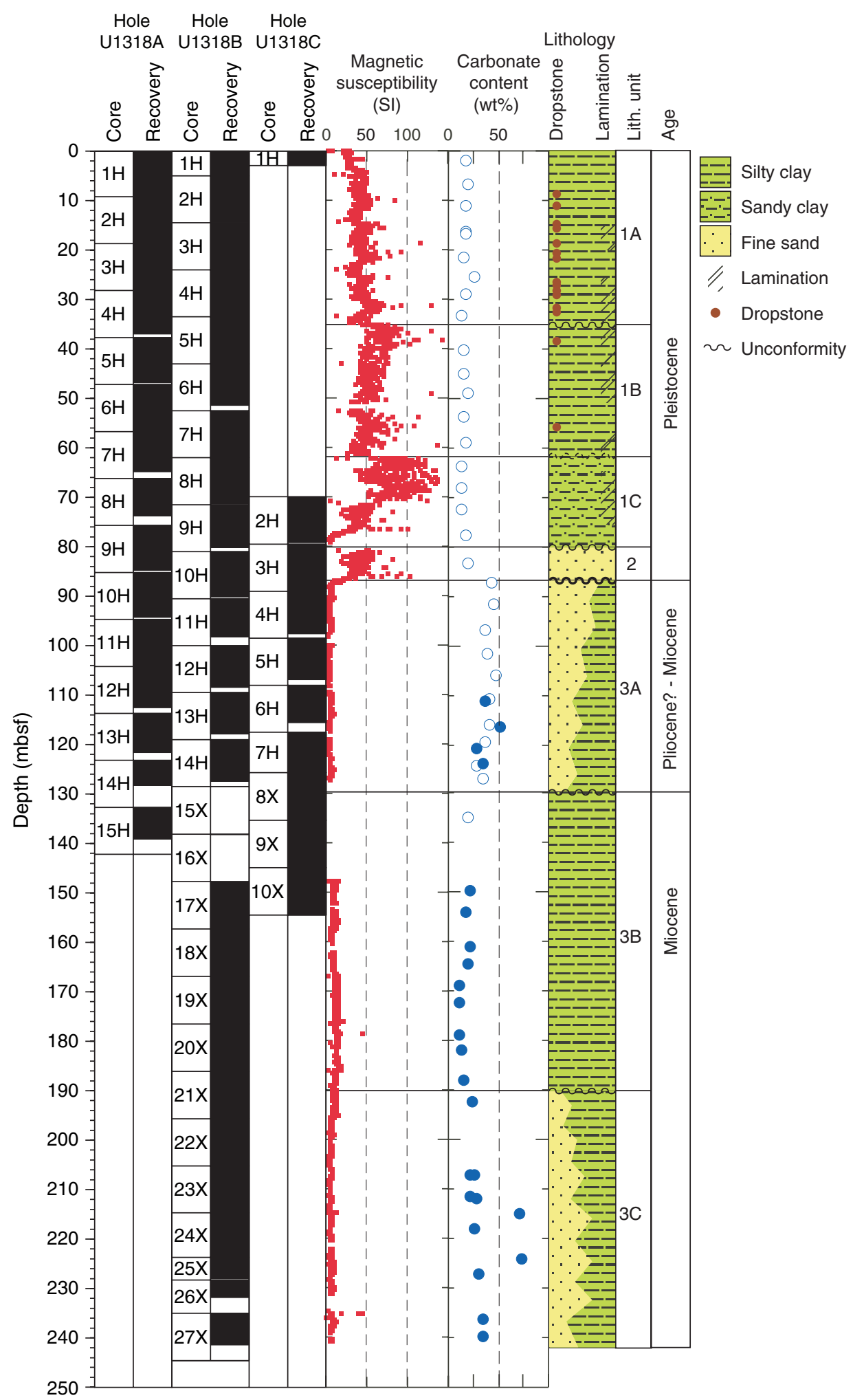




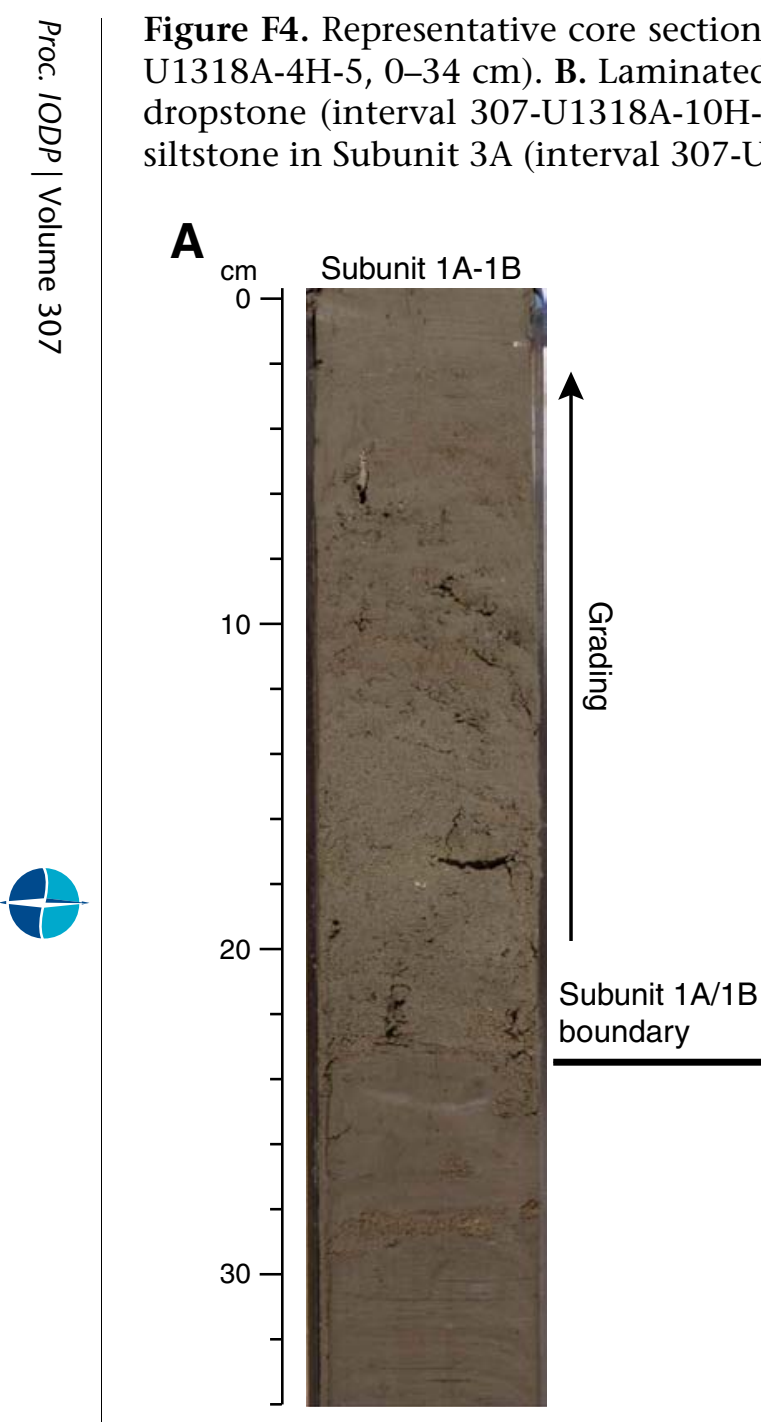

Figure F4. Representative core sections of different lithostratigraphic units. A. Grading sandstone layer at the base of Subunit 1A (interval 307U1318A-4H-5, 0-34 cm). B. Laminated silty clay in Subunit 1B (interval 307-U1318A-6H-2, 30-70 cm). C. Fine sandstone of Unit 2 containing a dropstone (interval 307-U1318A-10H-1, 96-129 cm) and gastropod (interval 307-U1318A-9H-6, 56-66 cm). D. Bioturbated light greenish gray siltstone in Subunit 3A (interval 307-U1318A-13H-5, 38-62 cm).

A

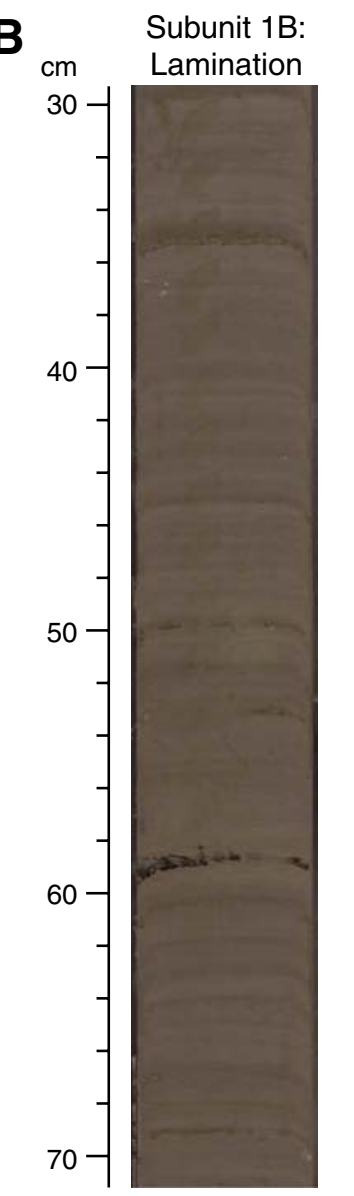

C

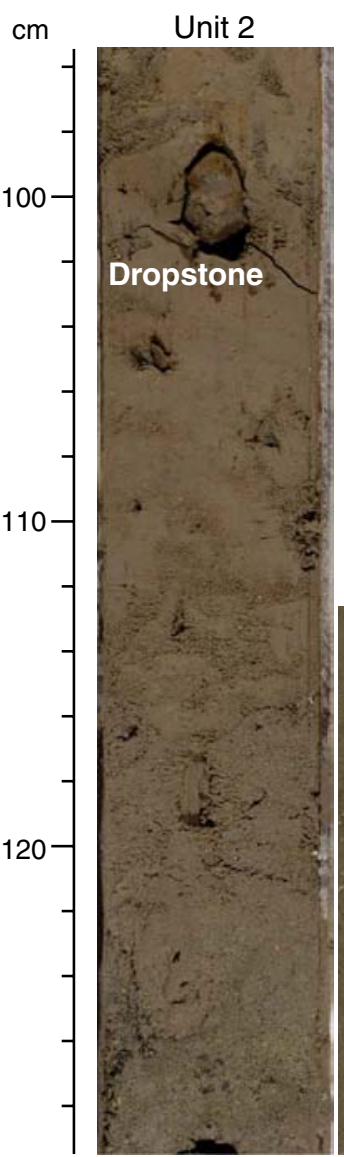

D

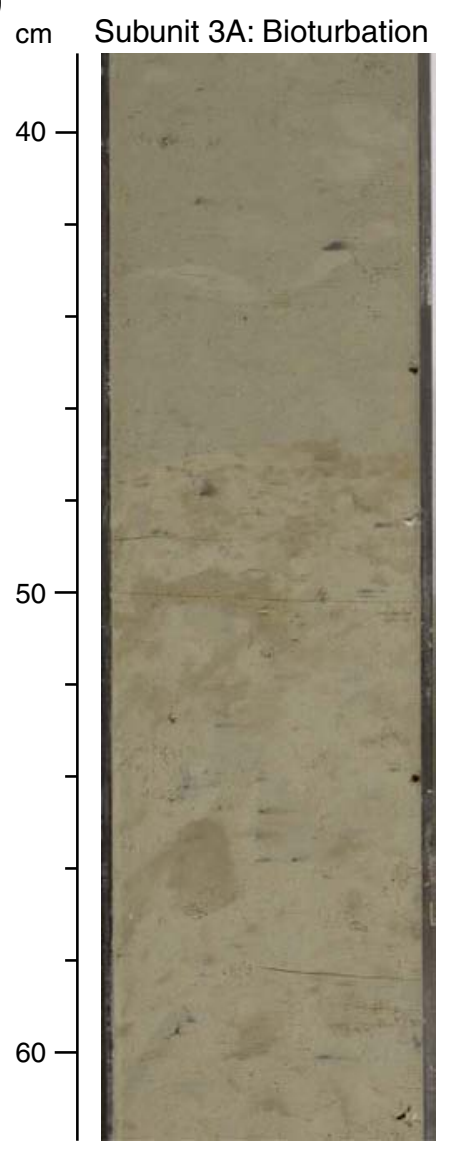

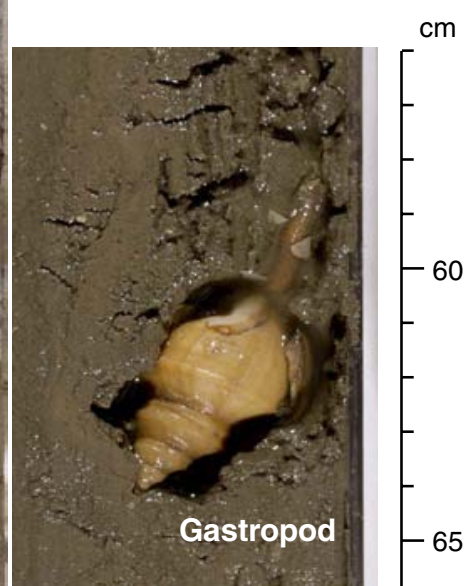


Figure F5. Core sections around the bivalve bed overlain by conglomerate. These sections include the boundary between lithostratigraphic Units 2 and 3. Calcareous nannofossil ages are shown with red arrows.

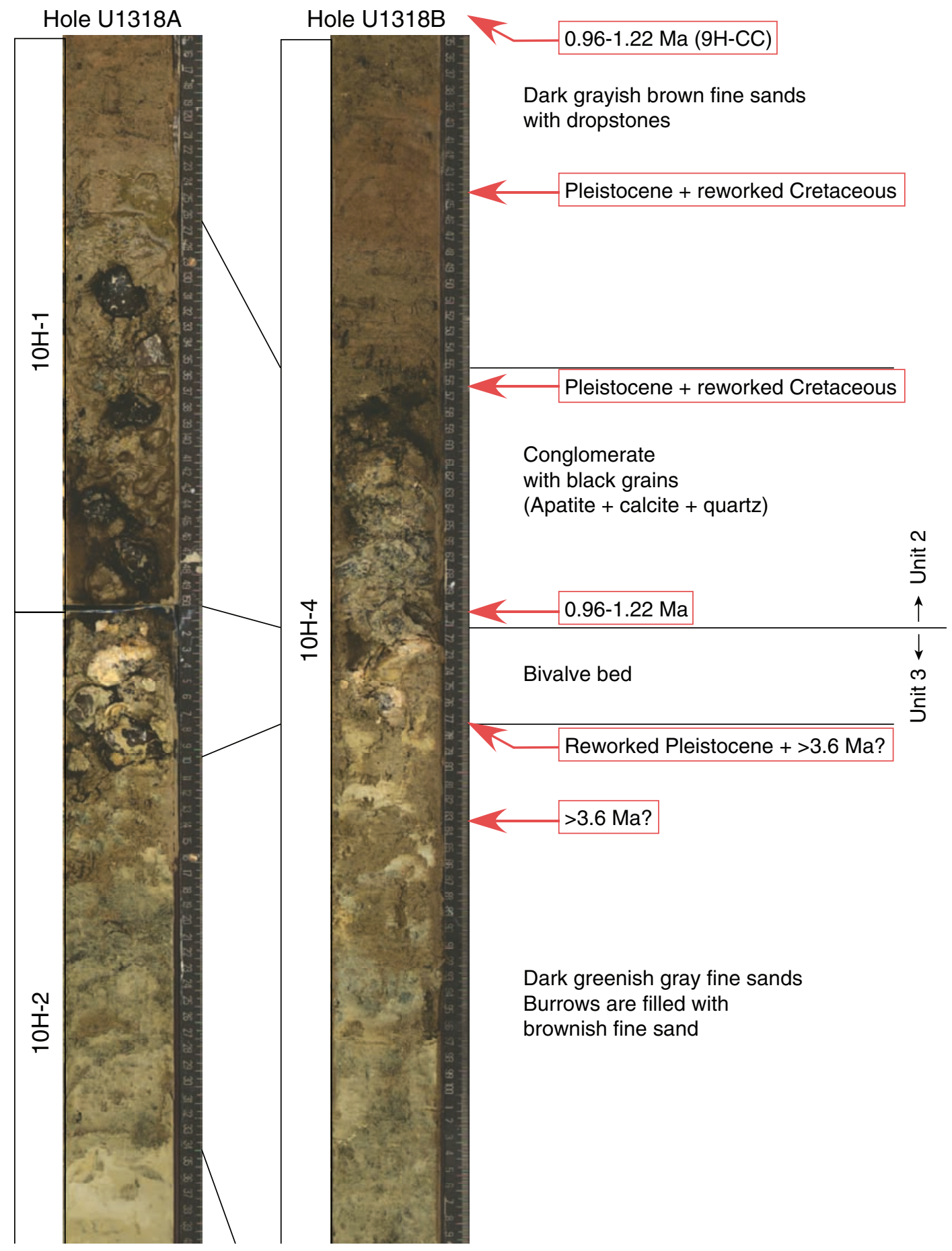


Figure F6. Stratigraphic position of calcareous nannofossil and planktonic foraminifer zones in Holes U1318A, U1318B, and U1318C. Wavy lines = hiatuses, dashed boundaries imply uncertainly.

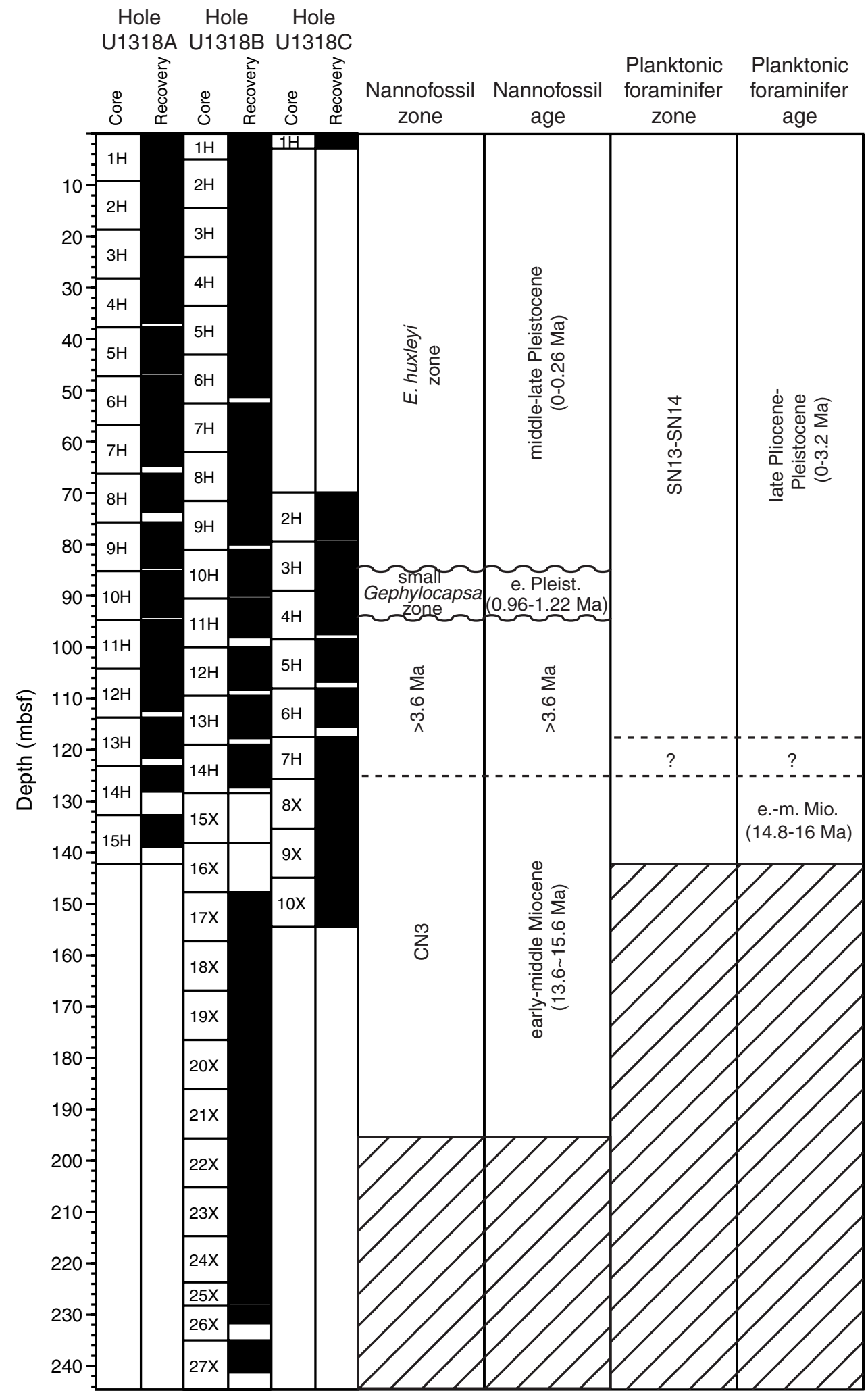


Figure F7. Planktonic foraminifer biostratigraphy of Hole U1318A. Age of Section 307-U1318A-12H-CC (112.5 mbsf) is regarded as late Pliocene to Pleistocene. Section 307-U1318A-14H-CC is assigned to lowermiddle Miocene (14.8-16.0 Ma). Upward flags = FAD, downward flags = LAD.

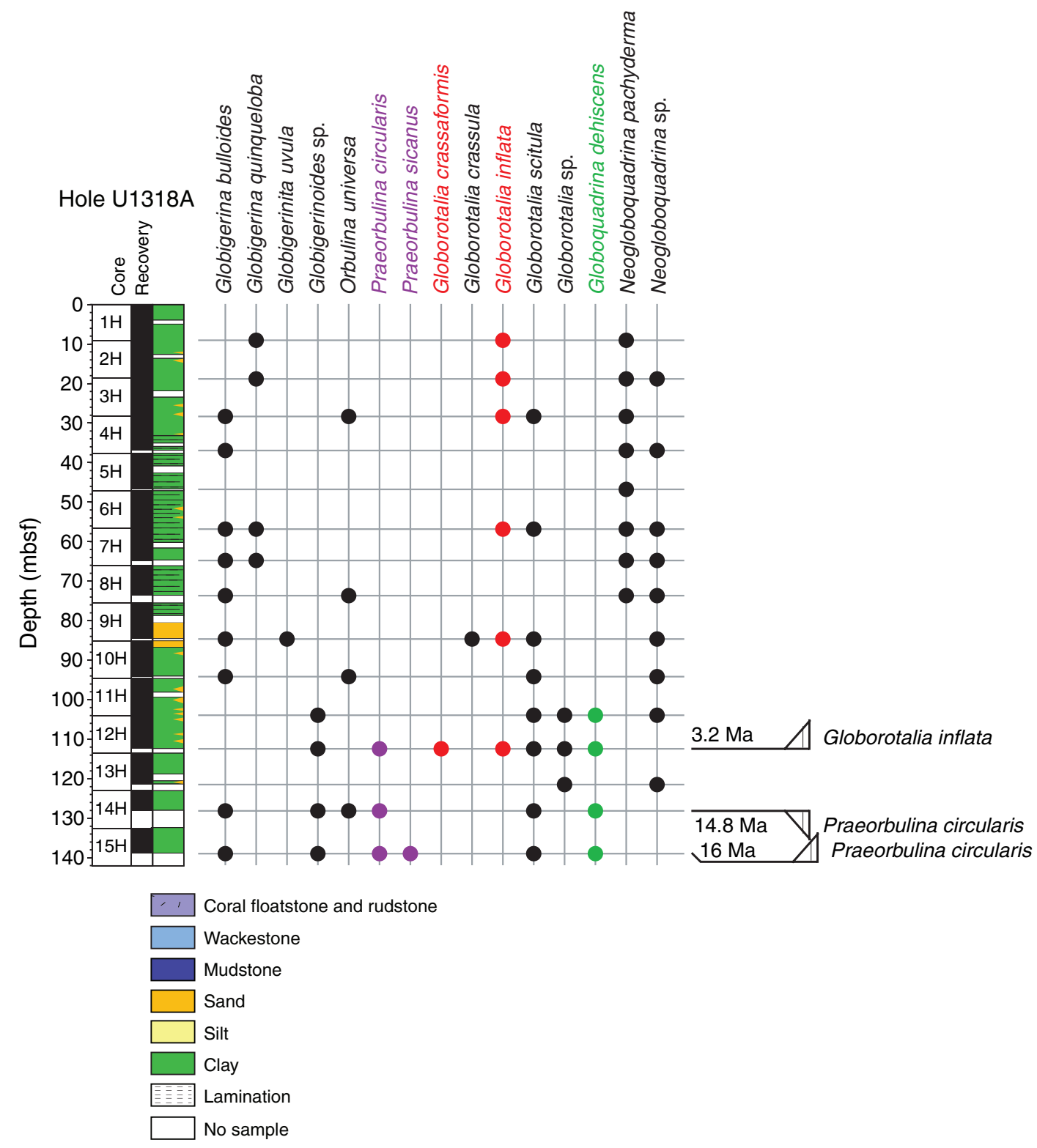


Figure F8. Occurrence of benthic foraminifers from core catcher of each core in Hole U1318A. Assemblages in lithostratigraphic Unit 1 are low in diversity and dominated by shallow-water species.

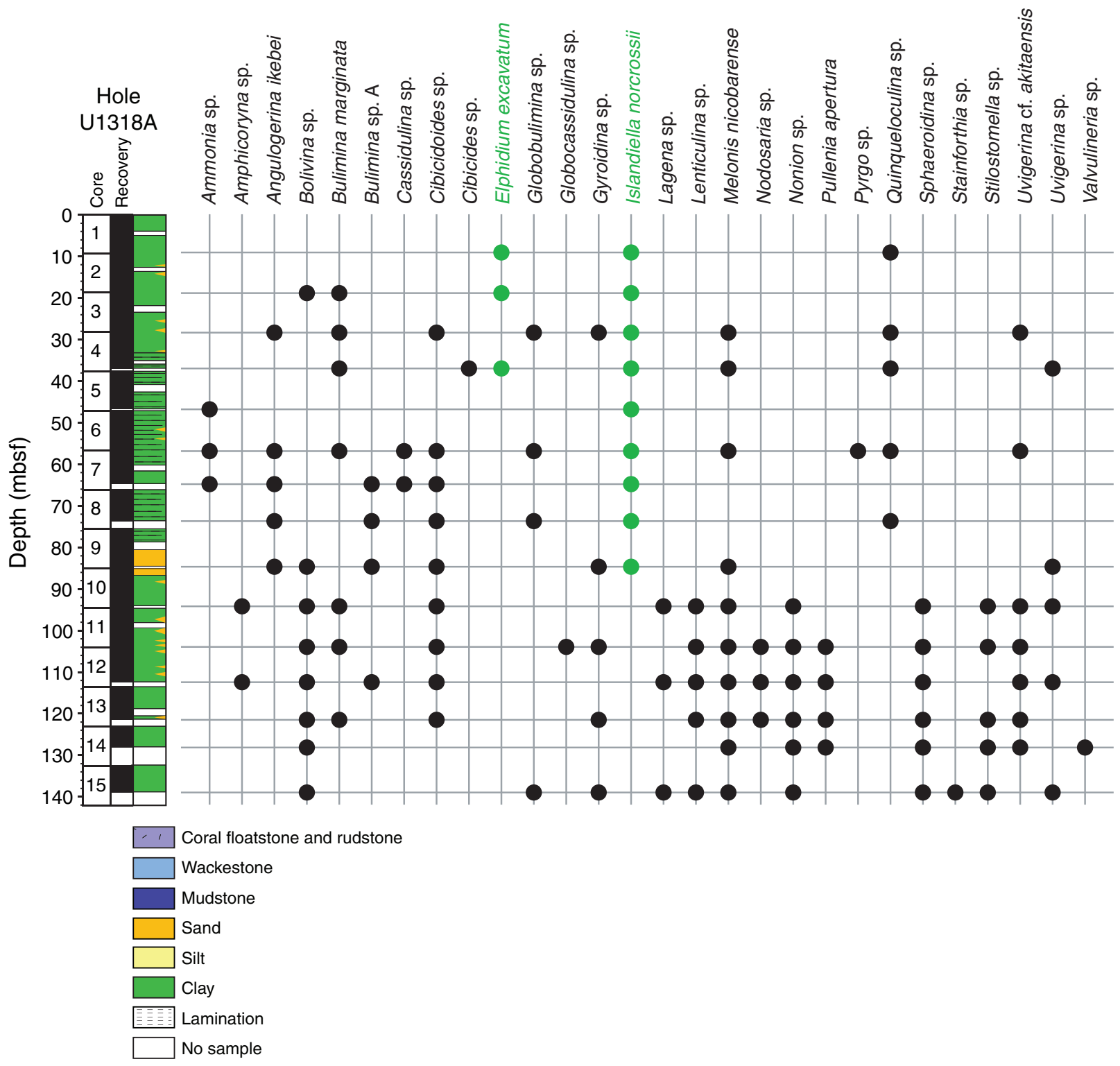


Figure F9. Lithostratigraphy of all three sites projected on the seismic profile of Challenger Mound along a north-northwest to south-southeast transect. P1-P3 refers to seismic units as defined by Van Rooij et al. (2003).

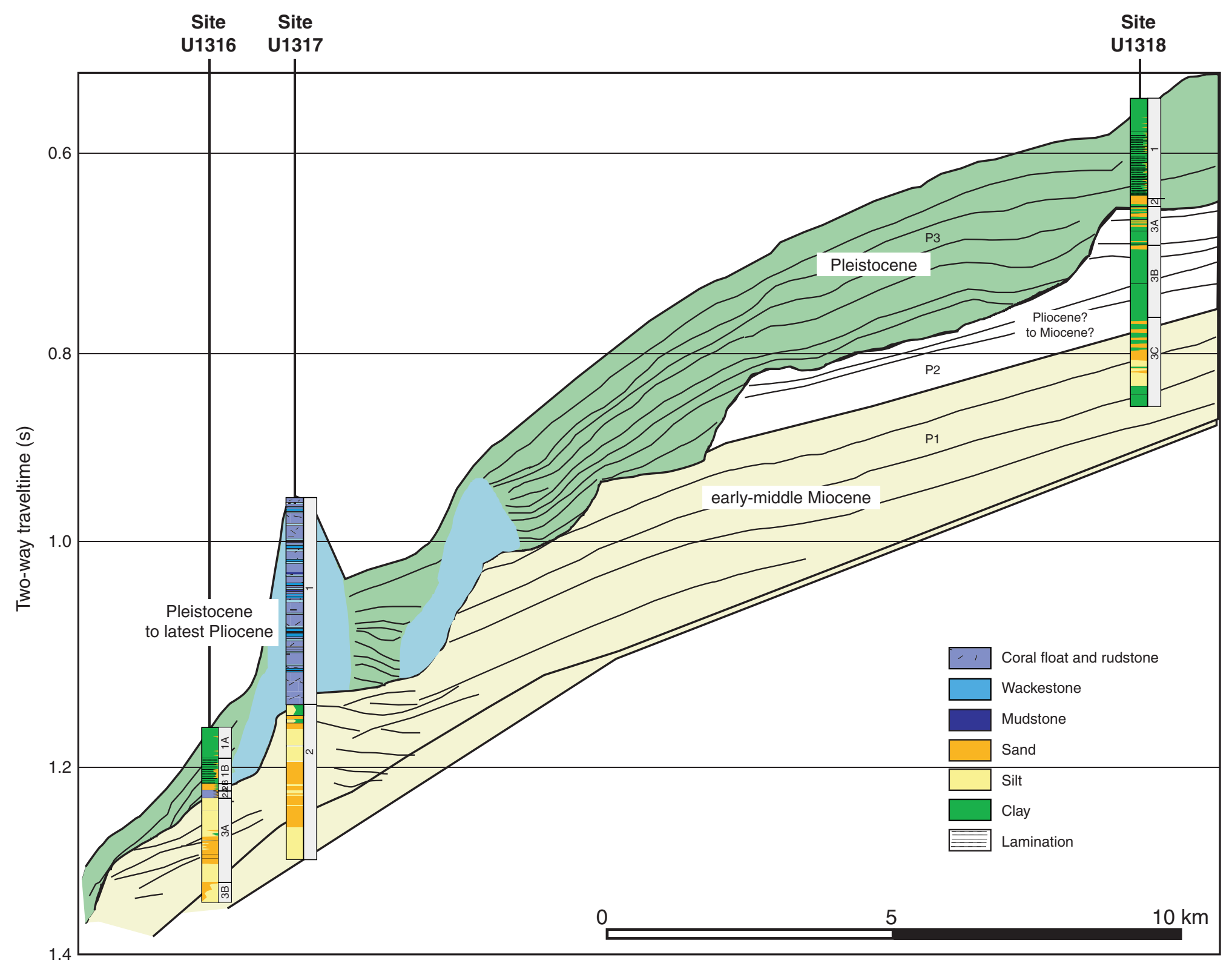


Figure F10. Stepwise AF demagnetization of Section 307-U1318A-1H-1 at (A) 0.25 mbsf and (B) 3.15 mbsf. Left panels represent orthogonal projection of endpoints of the magnetization vector. Open symbols $=$ projection on vertical plane, solid symbols = projection on horizontal plane. Middle panels represent change in magnetization intensity during AF demagnetization. Right panels represent equal area projection of magnetization vector during demagnetization.

A

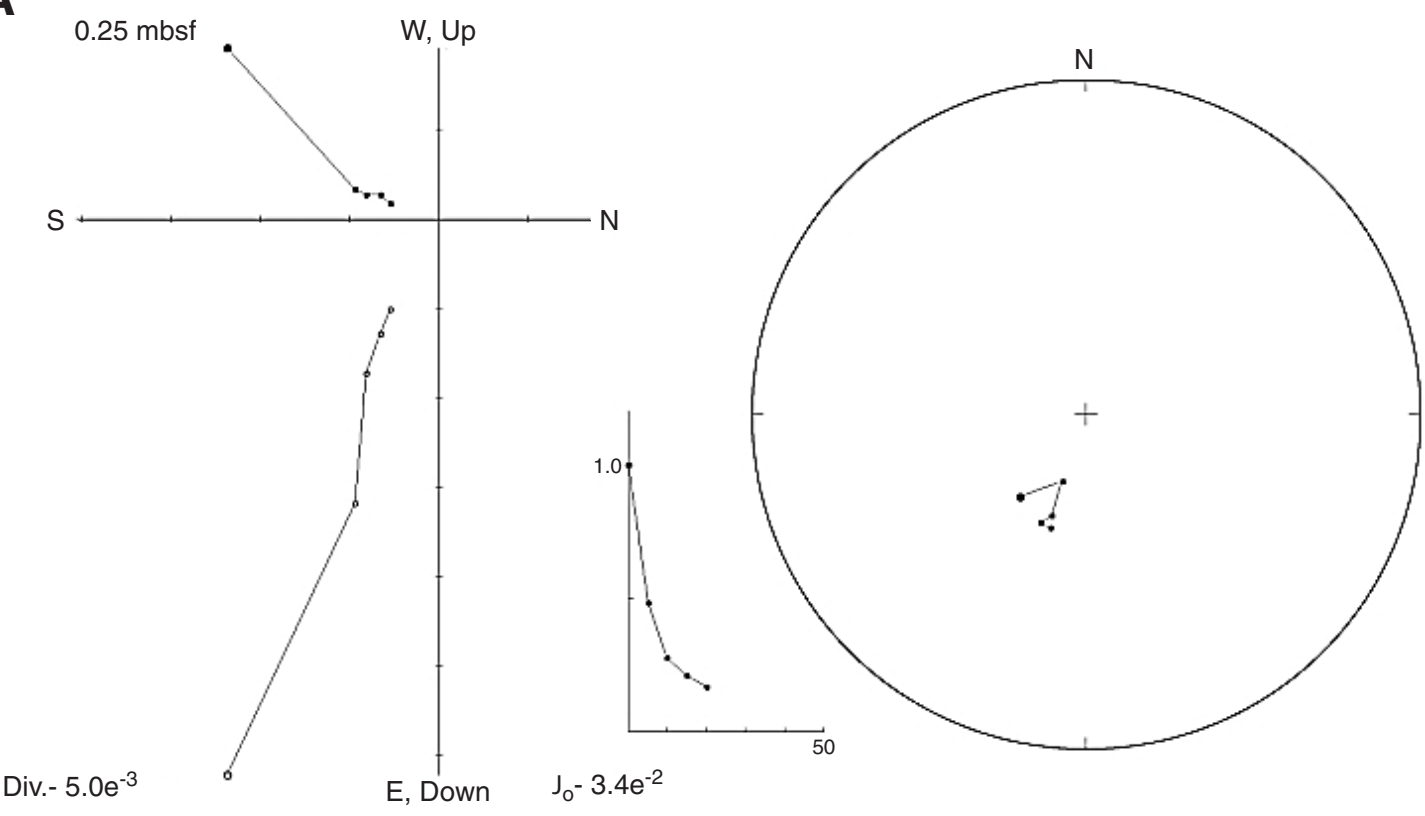

B

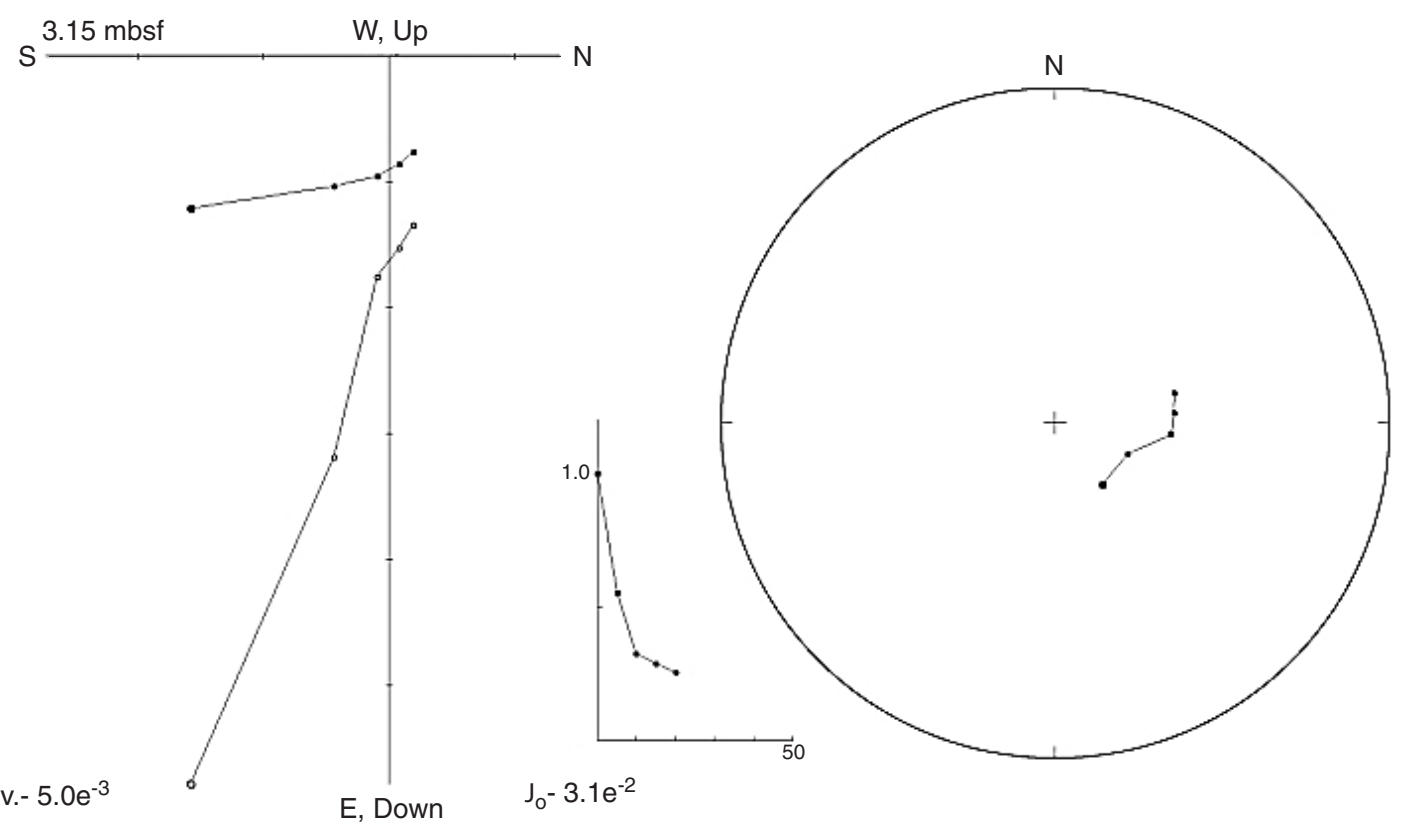


Figure F11. Inclination of the magnetization vector vs. depth in Holes U1318A, U1318B, and U1318C after AF demagnetization at peak fields of $15 \mathrm{mT}$.

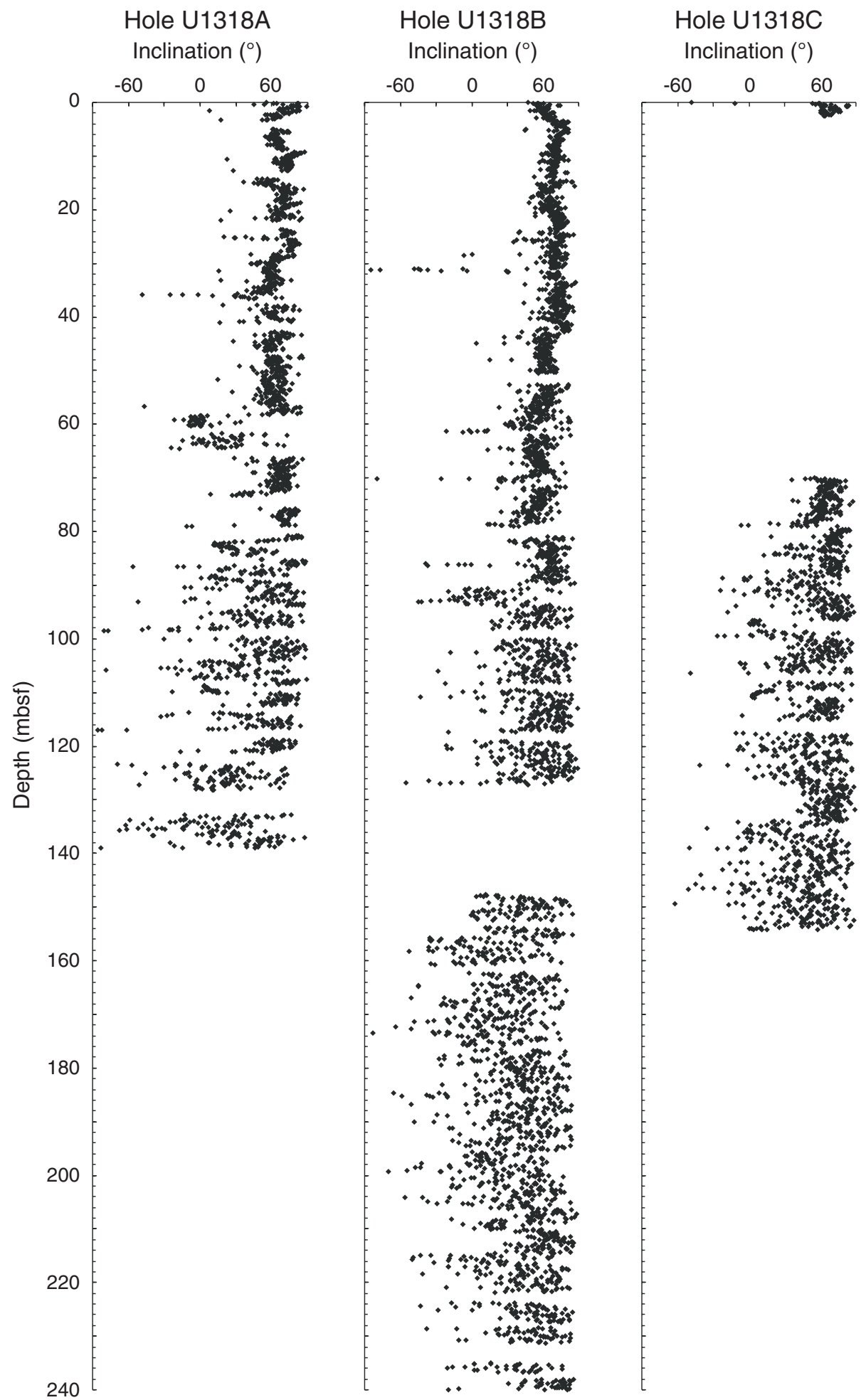


Figure F12. Declination of magnetization vector vs. depth in Holes U1318A, U1318B, and U1318C after AF demagnetization at peak fields of $15 \mathrm{mT}$.

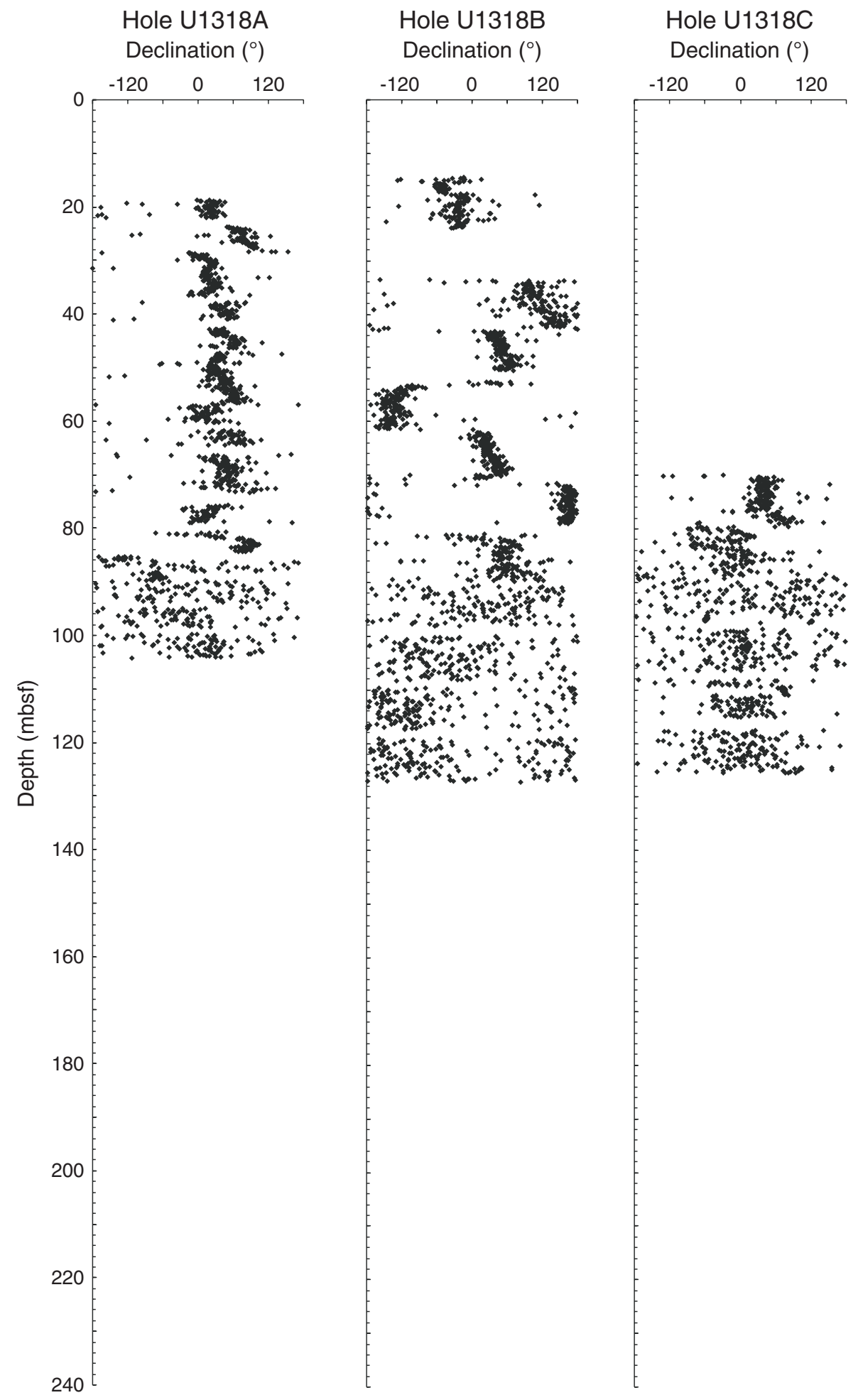


Figure F13. Intensity of magnetization vector vs. depth in Holes A U1318, U1318B, and U1318C after AF demagnetization at peak fields of $15 \mathrm{mT}$.

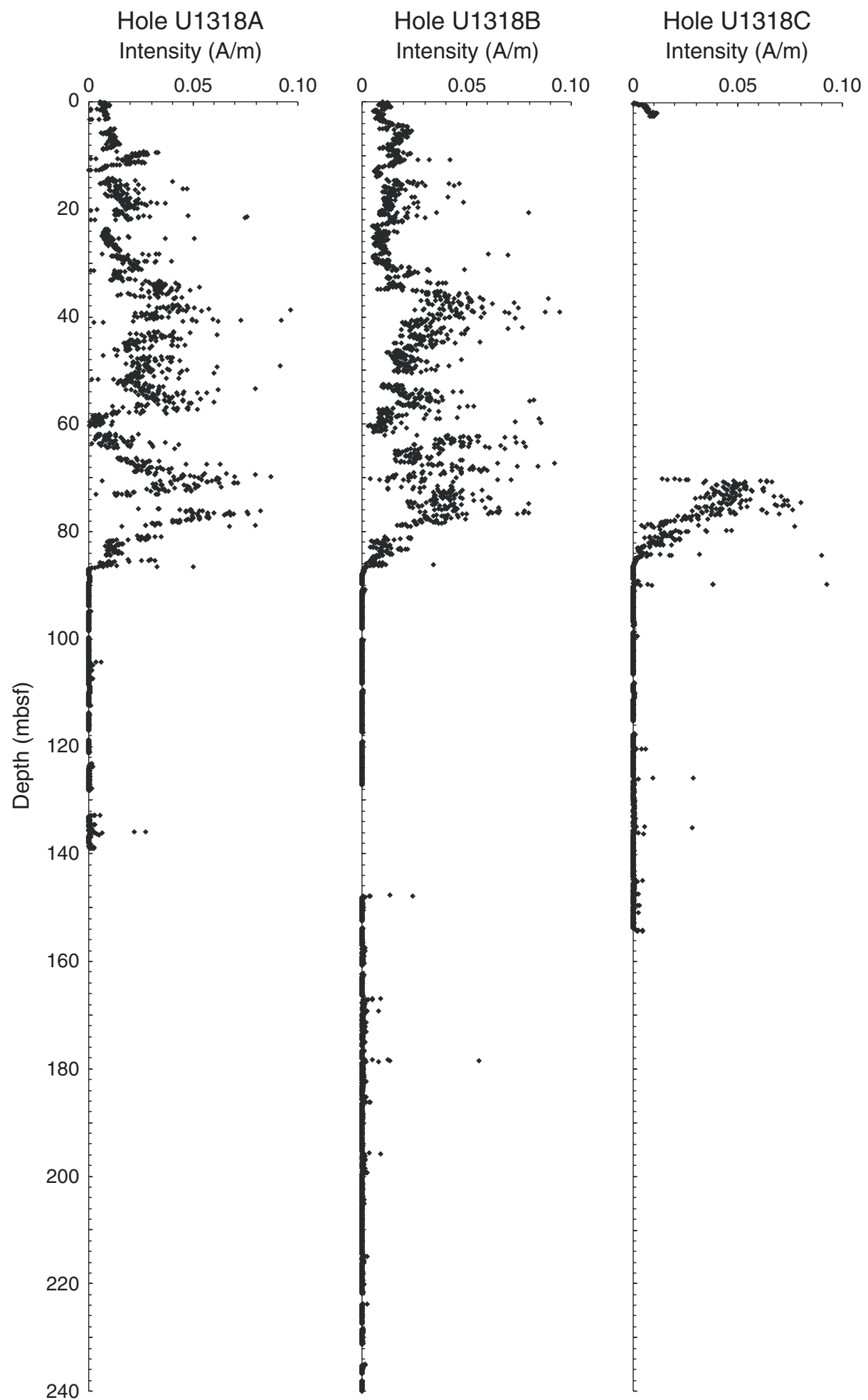


Figure F14. Chlorinity vs. depth. Open squares = Hole U1318A, solid squares = Hole U1318B.

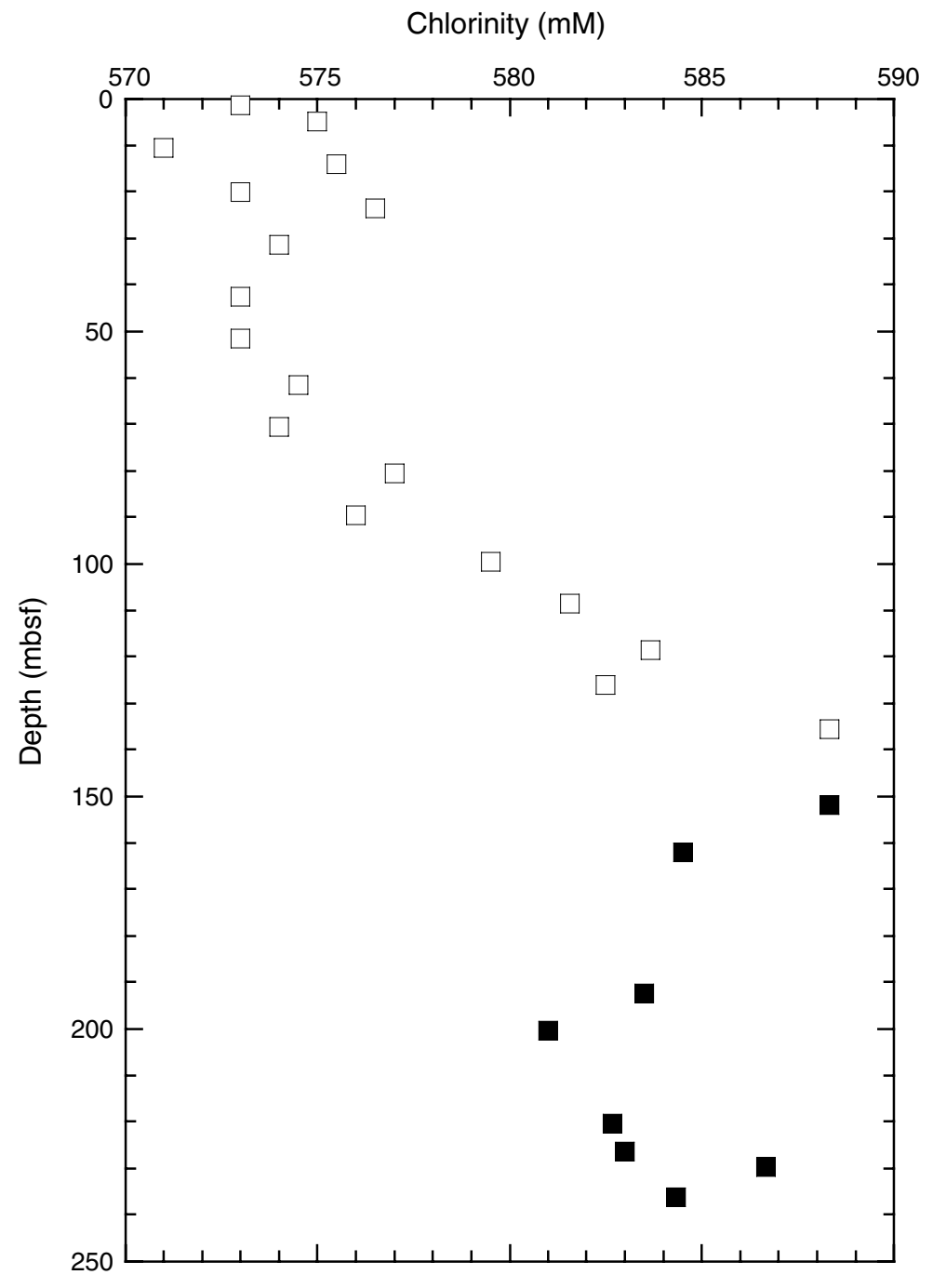


Figure F15. Concentrations of dissolved chemical species vs. depth. A. Sulfate. B. Alkalinity. C. Dissolved organic carbon (DIC). D. Ammonium. E. Iron. F. Manganese. G. Barium. Open squares = Hole U1318A, solid squares = Hole U1318B.

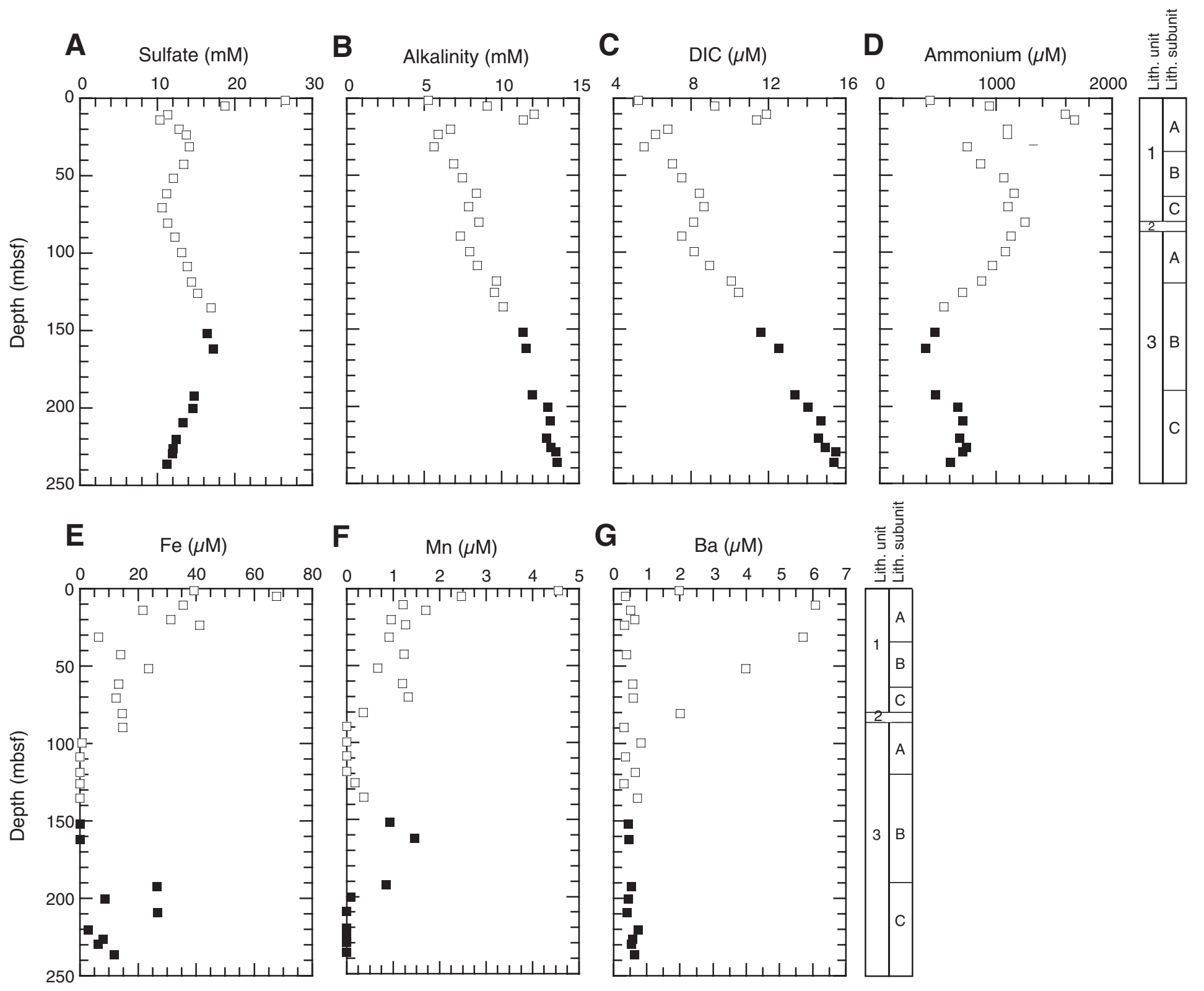


Figure F16. Concentrations of dissolved chemical species vs. depth. A. Calcium. B. Magnesium. Open squares = Hole U1318A, solid squares = Hole U1318B.

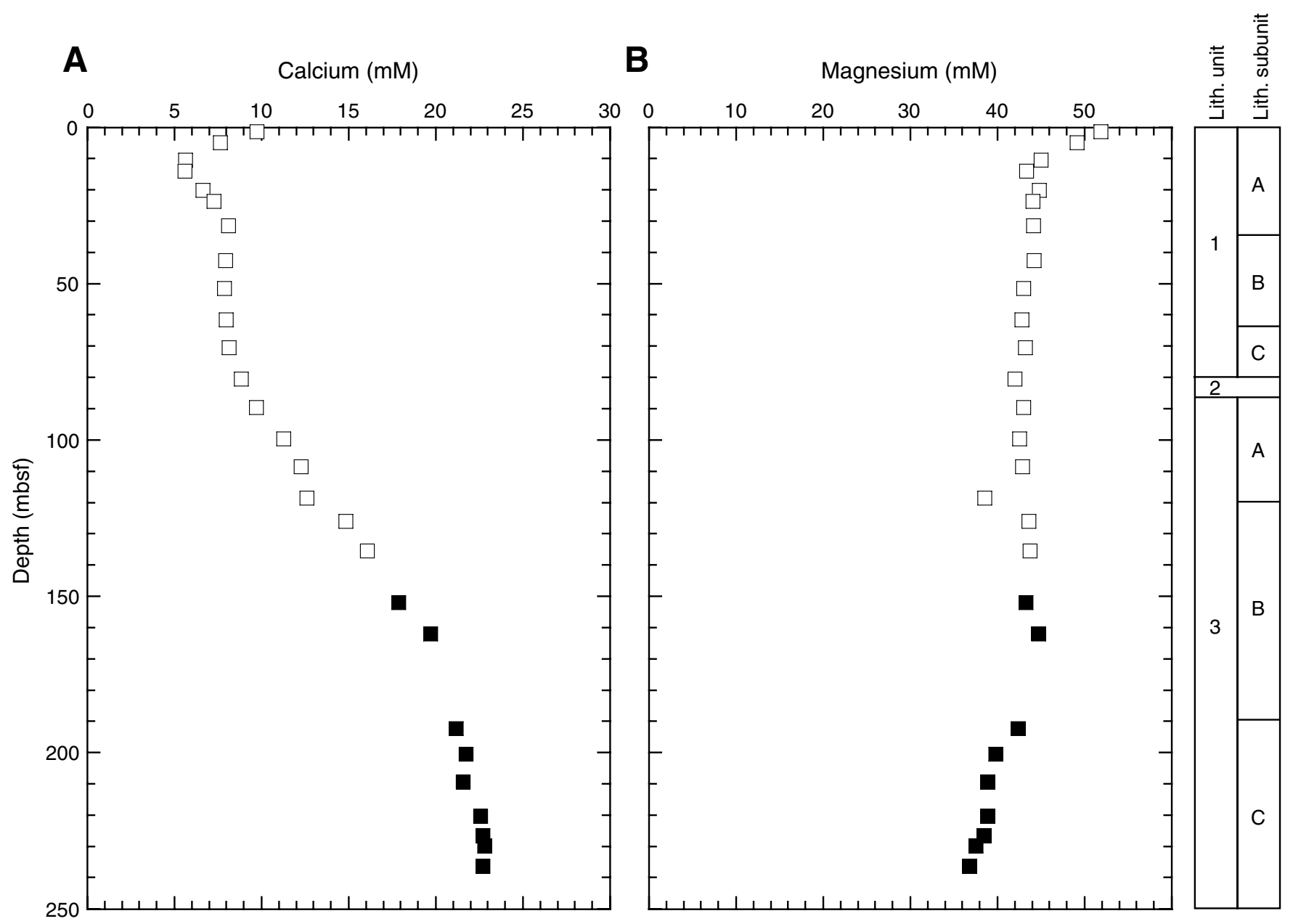


Figure F17. Concentrations of dissolved chemical species vs. depth. A. Silica. B. Boron. C. Strontium. D. Lithium. Open squares = Hole U1318A, solid squares = Hole U1318B.

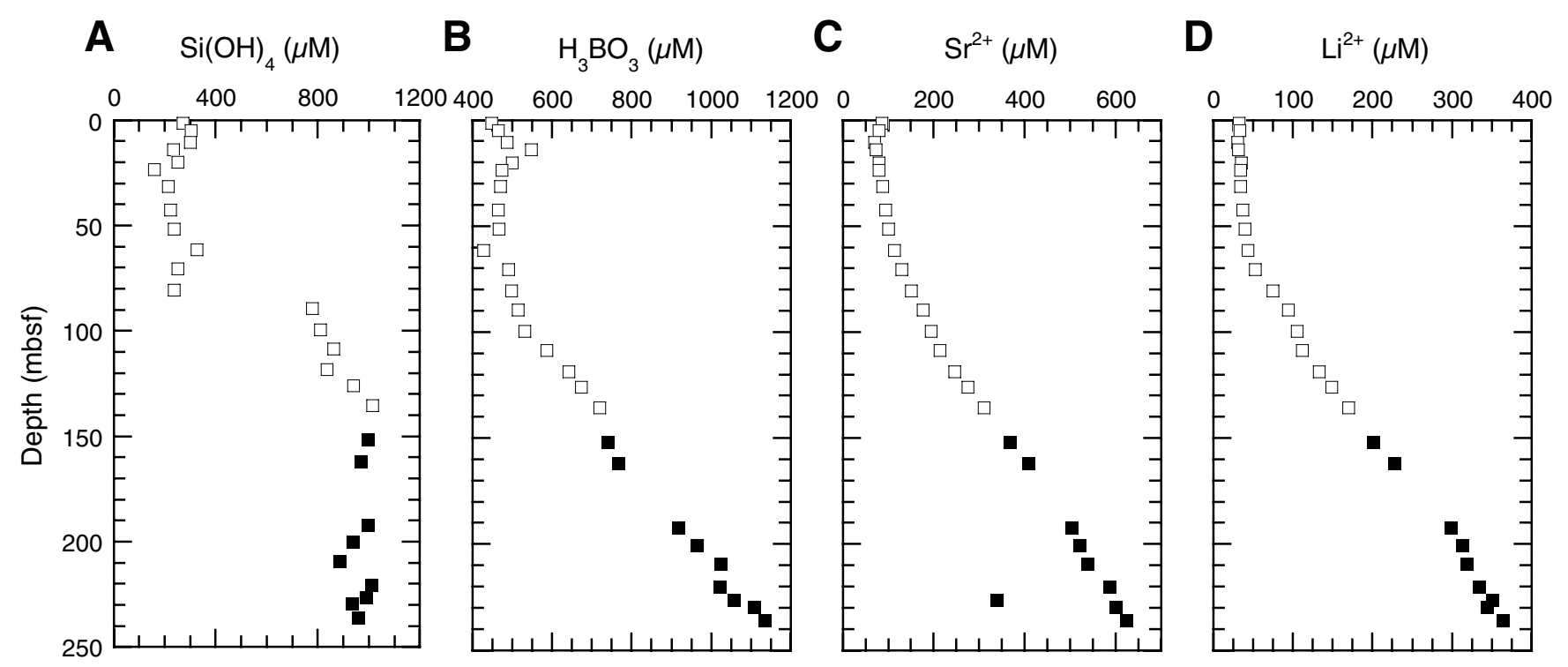


Figure F18. Carbonate content vs. depth. Open squares = Hole U1318A, solid squares = Hole U1318B.

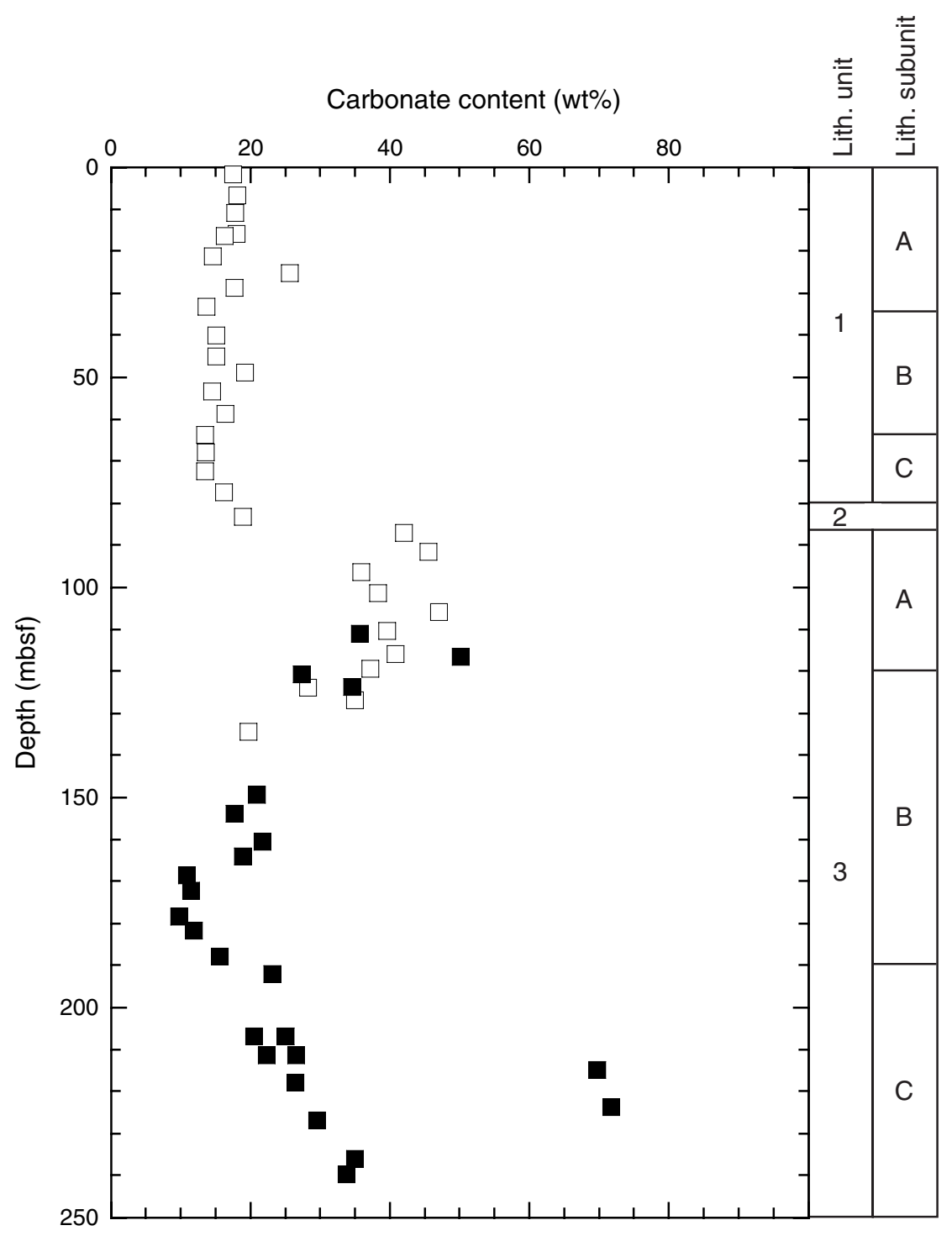


Figure F19. Graphic representation of subsampling and analysis program for the MBIO core sections from Hole U1318A. The sequence of subsections runs from the top of the core (right) to the bottom (left). See Table T4 in the "Methods" chapter for explanation of sampling codes.

\begin{tabular}{|c|c|c|c|c|c|c|c|c|c|c|}
\hline 307-U1318A & \multicolumn{8}{|c|}{ CATWALK } & & \\
\hline CURATORS CODE & $\mathrm{IW}$ & AODC & \multirow{2}{*}{\multicolumn{6}{|c|}{ CONT-PFC PONT-BEADS }} & \multicolumn{2}{|c|}{ Core depth } \\
\hline approx. sample size (cm) & $15-20$ & 1 & & & & & & & \multirow{2}{*}{\multicolumn{2}{|c|}{ mbsf }} \\
\hline Sample Type & WRC & 1 syringe & 2 syringe & 1 syringe & 1 syring & 1 syringe & 1 syringe & 1 syringe & & \\
\hline Core & core end & & & core end $\mathrm{a}$ & after cutti & IW WRC & & & top & bottom \\
\hline $1 \mathrm{H}$ & 2 & 1 & 2 & 1 & 2 & 2 & 2 & 2 & 0.00 & 9.20 \\
\hline $2 \mathrm{H}$ & 2 & 1 & 2 & 1 & 2 & 2 & 2 & 2 & 9.20 & 18.70 \\
\hline $3 \mathrm{H}$ & 2 & 1 & 2 & 1 & 1 & 1 & 1 & 1 & 18.70 & 28.30 \\
\hline $4 \mathrm{H}$ & 1 & - & - & - & 1 & 1 & 1 & 1 & 28.30 & 37.70 \\
\hline $5 \mathrm{H}$ & 1 & 1 & 2 & 1 & 1 & 1 & 1 & 1 & 37.70 & 47.20 \\
\hline $6 \mathrm{H}$ & 1 & 1 & 2 & 1 & 1 & 1 & 1 & 1 & 47.20 & 56.70 \\
\hline $7 \mathrm{H}$ & 1 & 1 & 2 & 1 & 1 & 1 & 1 & 1 & 56.70 & 66.20 \\
\hline $8 \mathrm{H}$ & 1 & 1 & 2 & 1 & 1 & 1 & 1 & 1 & 66.20 & 75.70 \\
\hline $9 \mathrm{H}$ & 1 & 1 & 2 & 1 & 1 & 1 & 1 & 1 & 75.70 & 85.20 \\
\hline $10 \mathrm{H}$ & 1 & 1 & 2 & 1 & 1 & 1 & 1 & 1 & 85.20 & 94.70 \\
\hline $11 \mathrm{H}$ & 1 & 1 & 2 & 1 & 1 & 1 & 1 & 1 & 94.70 & 104.20 \\
\hline $12 \mathrm{H}$ & 1 & 1 & 2 & 1 & 1 & 1 & 1 & 1 & 104.20 & 113.70 \\
\hline $13 \mathrm{H}$ & 1 & 1 & 2 & 1 & 1 & 1 & 1 & 1 & 113.70 & 123.20 \\
\hline $14 \mathrm{H}$ & 1 & 1 & 1 & 1 & 1 & 1 & 1 & 1 & 123.20 & 132.70 \\
\hline $15 \mathrm{H}$ & 1 & 1 & 1 & 1 & 1 & 1 & 1 & 1 & 132.70 & 142.20 \\
\hline TOTAL & 18 & 14 & 26 & 14 & 17 & 17 & 17 & 17 & 140 & Samples \\
\hline
\end{tabular}

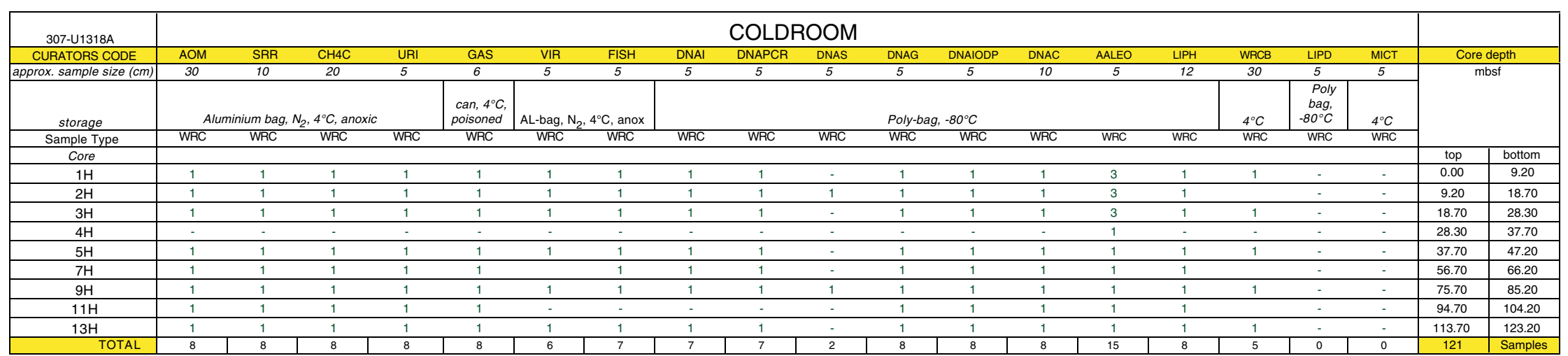


Figure F20. Graphic representation of subsampling and analysis program for the MBIO core sections from Hole U1318B. The sequence of subsections runs from the top of the core (right) toward the bottom (left). See Table T4 in the "Methods" chapter for explanation of sampling codes.

\begin{tabular}{|c|c|c|c|c|c|c|c|c|c|c|}
\hline 307-U1318B & \multicolumn{8}{|c|}{ CATWALK } & \multirow{2}{*}{\multicolumn{2}{|c|}{ Core depth }} \\
\hline CURATORS CODE & IW & AODC & \multirow{2}{*}{\multicolumn{6}{|c|}{ CONI-PFCFONI-BEAD? }} & & \\
\hline approx. sample size $(\mathrm{cm})$ & $15-20$ & 1 & & & & & & & \multicolumn{2}{|c|}{$\mathrm{mbst}$} \\
\hline Sample Type & WRC & 1 syringe & 2 syringe & 1 syringe & 1 syringe & 1 syringe & 1 syringe & 1 syringe & & \\
\hline Core & core end & & & core end af & er cuttinalW & WRC & & & top & bottom \\
\hline $17 X$ & 1 & 1 & & 1 & 1 & 1 & 1 & 1 & 147.70 & 157.30 \\
\hline $18 \mathrm{X}$ & 1 & 1 & 2 & 1 & 1 & - & 1 & - & 157.30 & 166.90 \\
\hline $19 \mathrm{X}$ & 1 & 1 & 2 & 1 & 1 & 1 & 1 & 1 & 166.90 & 176.50 \\
\hline $20 x$ & 1 & 1 & 2 & 1 & 1 & 1 & 1 & 1 & 176.50 & 186.10 \\
\hline $21 x$ & 1 & 1 & 2 & 1 & 1 & 1 & 1 & 1 & 186.10 & 195.70 \\
\hline $22 X$ & 1 & 1 & 2 & 1 & 1 & 1 & 1 & 1 & 195.70 & 205.20 \\
\hline $23 x$ & 1 & 1 & 2 & 1 & 1 & 1 & 1 & 1 & 205.20 & 214.70 \\
\hline $24 X$ & 1 & 1 & 2 & 1 & 1 & 1 & 1 & 1 & 214.70 & 223.70 \\
\hline $25 x$ & 1 & 1 & 2 & 1 & 1 & 1 & 1 & 1 & 223.70 & 228.30 \\
\hline $26 \mathrm{X}$ & 1 & 1 & 2 & 1 & 1 & 1 & 1 & 1 & 228.30 & 235.00 \\
\hline $27 x$ & 1 & 1 & 2 & 1 & 1 & 1 & 1 & 1 & 235.00 & 244.60 \\
\hline TOTAL & 11 & 11 & 20 & 11 & 11 & 10 & 11 & 10 & 95 & Samples \\
\hline
\end{tabular}

\begin{tabular}{|c|c|c|c|c|c|c|c|c|c|c|c|c|c|c|c|c|c|c|c|c|}
\hline $307-\mathrm{U} 1318 \mathrm{~B}$ & \multicolumn{18}{|c|}{ COLDROOM } & & \\
\hline CURATORS CODE & $\mathrm{AOM}$ & SRR & $\mathrm{CH} 4 \mathrm{C}$ & URI & GAS & VIR & FISH & DNAI & DNAPCR & DNAS & DNAG & DNAIODP & DNAC & AALEO & $\angle \mathrm{LPH}$ & WRCB & LIPD & MICT & \multicolumn{2}{|c|}{ Core depth } \\
\hline approx. sample size $(\mathrm{cm})$ & 30 & 10 & 20 & 5 & 6 & 5 & 5 & 5 & 5 & 5 & 5 & 5 & 10 & 5 & 12 & 30 & 5 & 5 & & \\
\hline storage & & ium ba & $4^{\circ} \mathrm{C}, \mathrm{a}$ & & $\begin{array}{c}\text { can, } 4^{\circ} \mathrm{C} \text {, } \\
\text { poisoned }\end{array}$ & AL-bag, I & $4^{\circ} \mathrm{C}$, anox & & & & Poly-ba &,$-80^{\circ} \mathrm{C}$ & & & & $4^{\circ} \mathrm{C}$ & \begin{tabular}{|} 
Poly \\
bog, \\
$-80^{\circ} \mathrm{C}$ \\
\end{tabular} & $4^{\circ} \mathrm{C}$ & & \\
\hline Sample Type & WRC & WRC & WRC & WRC & WRC & WRC & WRC & WRC & WRC & WRC & WRC & WRC & WRC & WRC & WRC & WRC & WRC & WRC & & \\
\hline $\begin{array}{c}\text { Core } \\
17 X\end{array}$ & 1 & 1 & 1 & 1 & 1 & 1 & 1 & 1 & 1 & 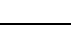 & 1 & 1 & 1 & 1 & 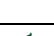 & 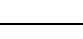 & $c^{2}$ & 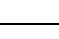 & top & \begin{tabular}{|l|} 
bottom \\
157.30 \\
\end{tabular} \\
\hline $18 x$ & 1 & 1 & 1 & 1 & 1 & 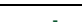 & 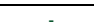 & -1 & - & - & 1 & 1 & 1 & 1 & 1 & - & 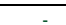 & - & 15730 & 166.90 \\
\hline $24 x$ & 1 & 1 & 1 & 1 & 1 & 1 & 1 & 1 & 1 & 1 & 1 & 1 & 1 & 1 & 1 & 1 & - & - & 214.70 & 223.70 \\
\hline $27 X$ & 1 & 1 & 1 & 1 & 1 & 1 & 1 & 1 & 1 & & 1 & 1 & 1 & 1 & 1 & & 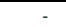 & & 235.00 & 244.60 \\
\hline TOTAL & 4 & 4 & 4 & 4 & 4 & 3 & 3 & 3 & 3 & 1 & 4 & 4 & 4 & 4 & 4 & 1 & 0 & 0 & 54 & Samples \\
\hline
\end{tabular}


Figure F21. A. Total prokaryotic cells (solid circles) vs. depth. Short dashed line = global prokaryote profile $\left(\right.$ Parkes et al., 2000) $\left(\log _{10}\right.$ cells $=8.03-$ $0.66 \times \log _{10}$ depth $\left.[\mathrm{m}]\right)$, long dashed lines $=$ upper and lower prediction limits for this profile, vertical line $=$ detection limit $\left(5.2 \log _{10}\right.$ cells $\left./ \mathrm{cm}^{3}\right)$. B. Percentage of the total population involved in cell division (open circles) versus depth. C. Geochemical profiles of sulfate (solid squares) and methane (crossed squares). Upper horizontal line = base of Subunit 1A at $33.3 \mathrm{mbsf}$, lower horizontal line = erosional boundary at $81.7 \mathrm{mbsf}$.

A Prokaryote cells $\left(\log _{10}\right.$ numbers $/ \mathrm{cm}^{3}$ )

B

Dividing cells (\%)

C

C Sulfate $(\mathrm{mM})$

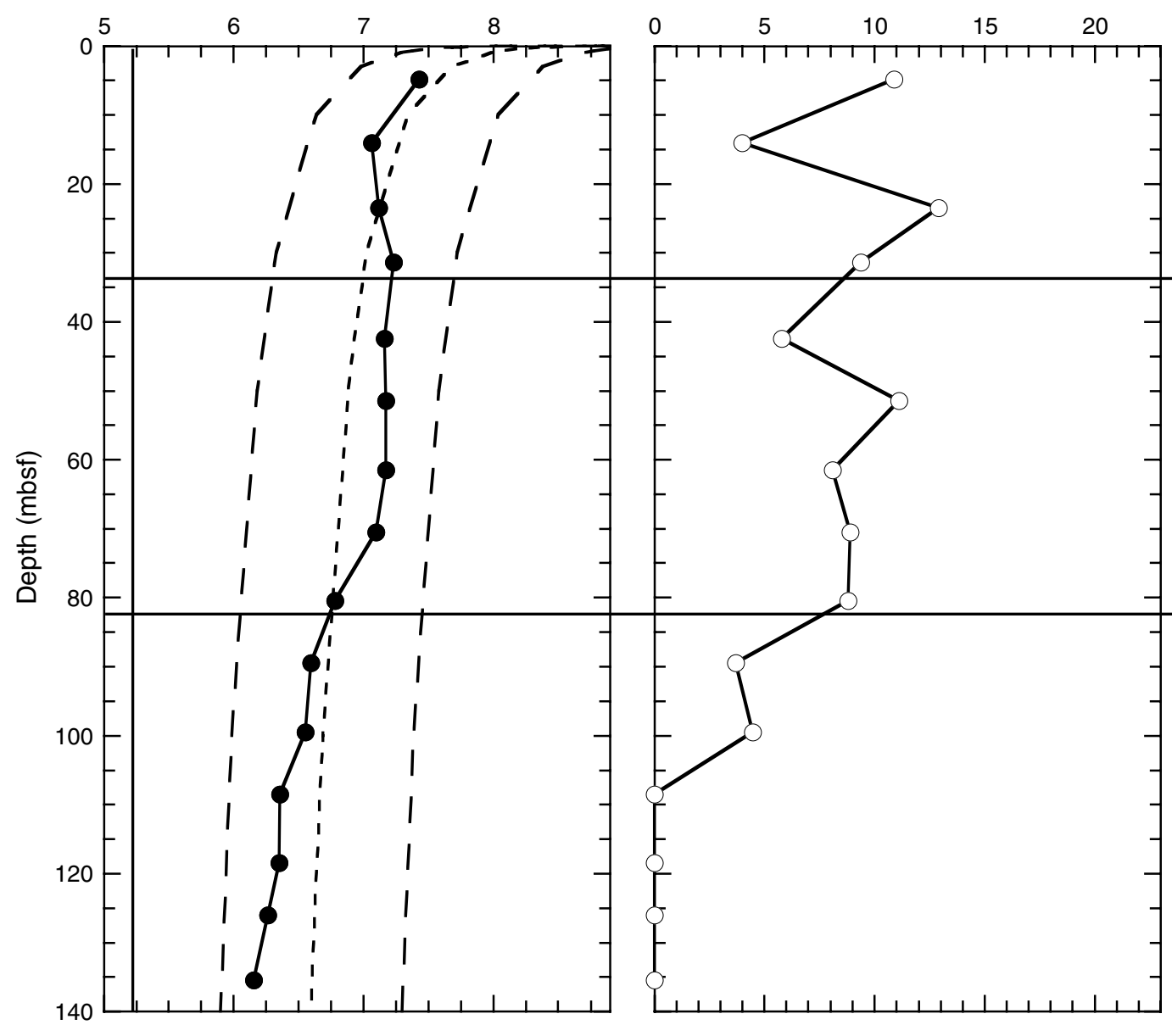

140

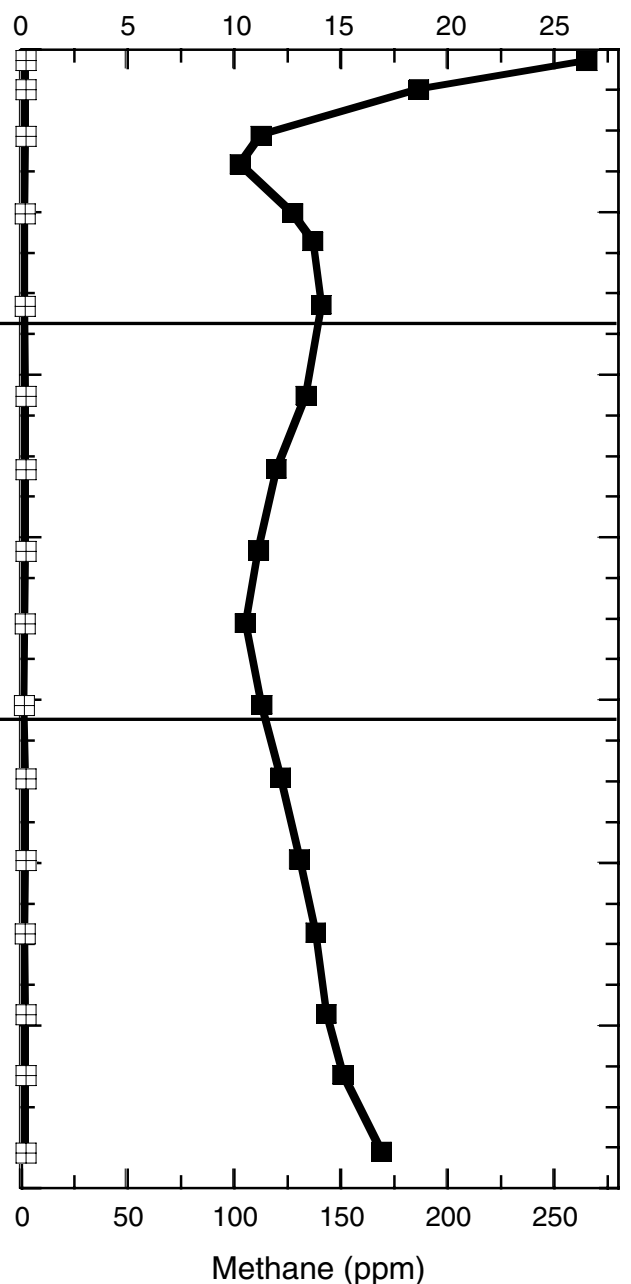


Figure F22. Overview of the spliced depth curves for physical properties correlated with local sparker seismics (P010520). Bulk density plotted by hole. Blue $=$ Hole U1318A, red $=$ Hole U1318B. GRA $=$ gamma ray attenuation, $\mathrm{PWL}=P$-wave logger, $\mathrm{PWS}=P$-wave sensor, red line $=$ running mean.

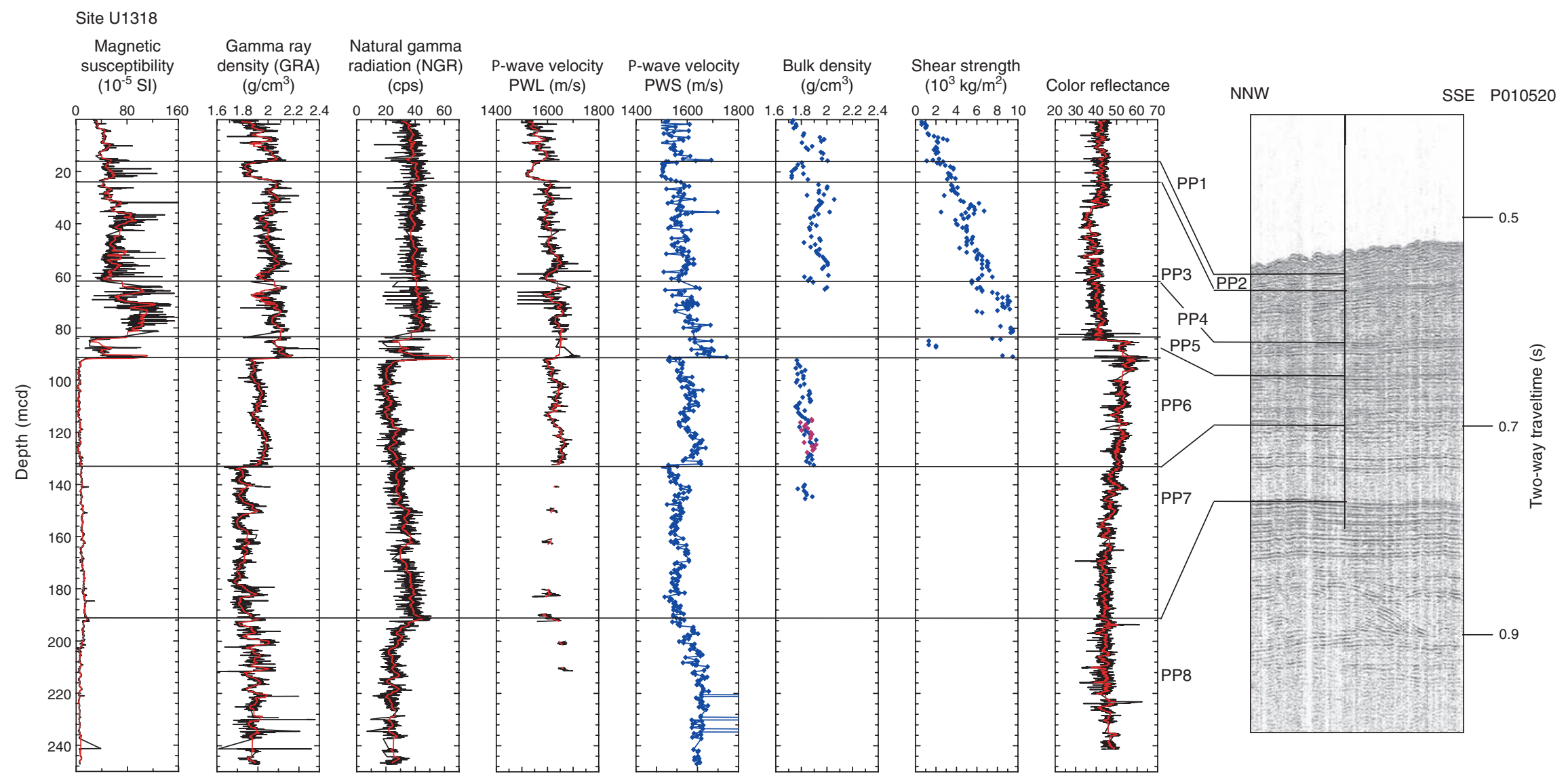


Figure F23. Temperature profile collected with the APCT tool in Hole U1318A.

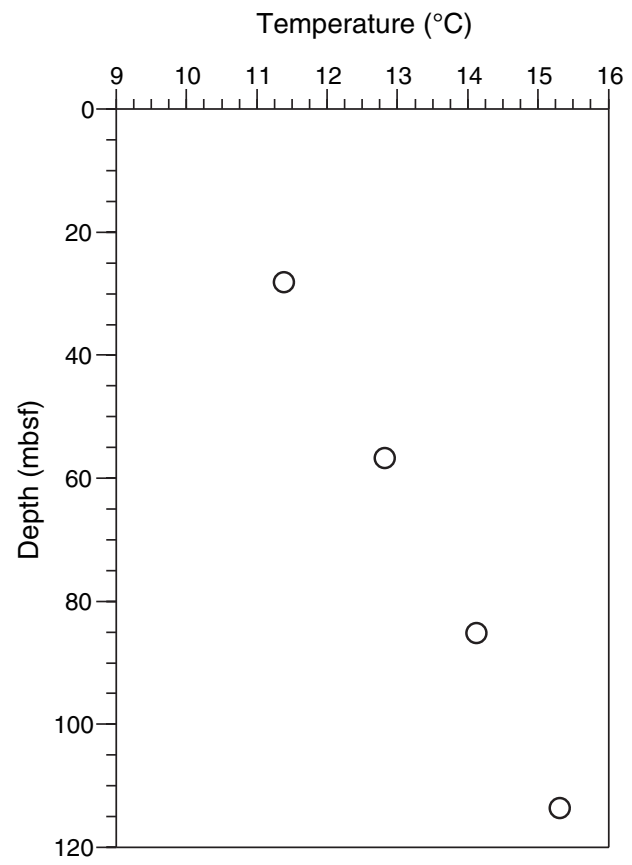


Figure F24. Correlation plots of physical properties. GRA = gamma ray attenuation, MS = magnetic susceptibility, NGR = natural gamma radiation, PWS $=P$-wave sensor.

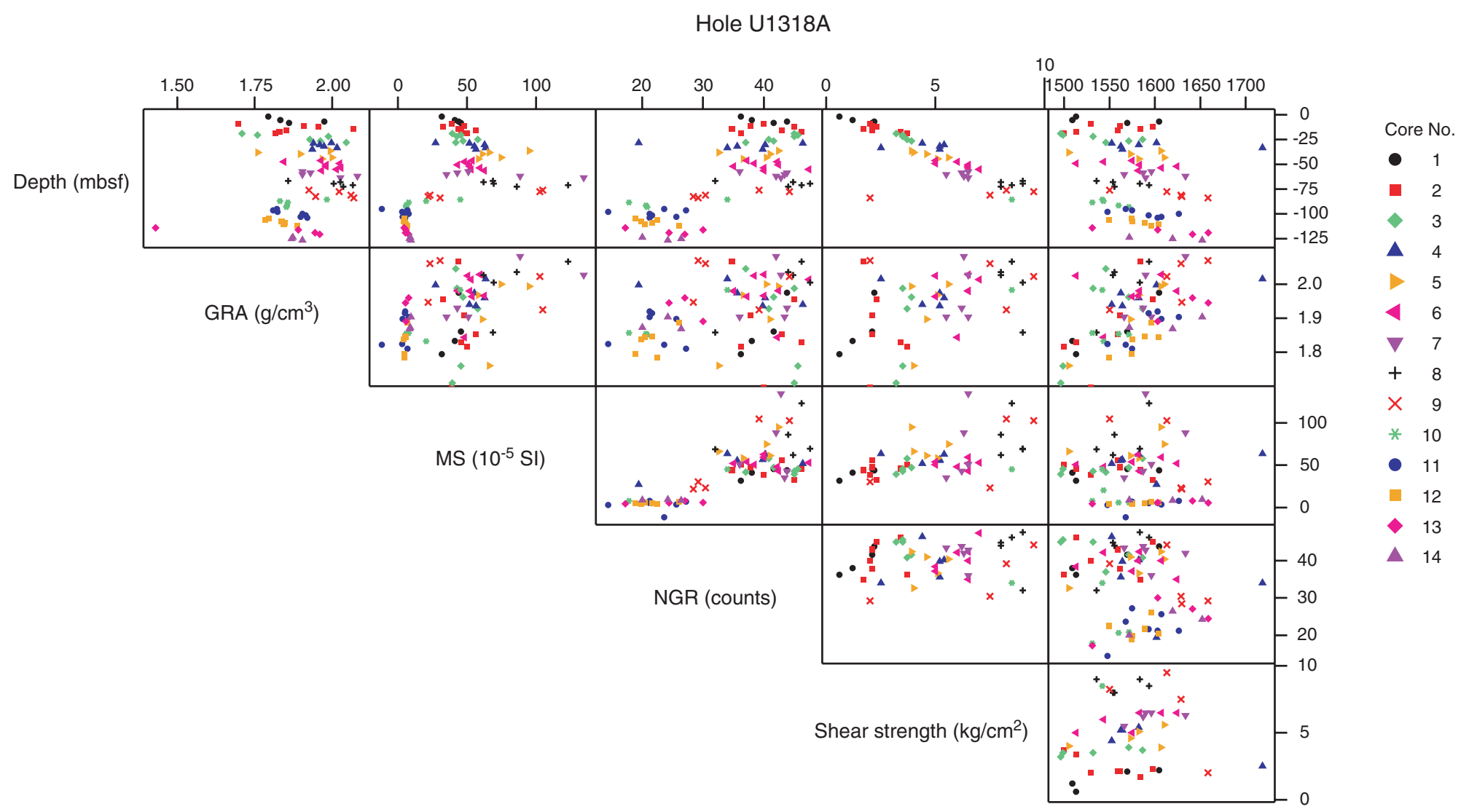

PWS velocity $(\mathrm{m} / \mathrm{s})$ 
Figure F25. Graphic summary of logging operations in Hole U1318C. FMS = Formation MicroScanner.

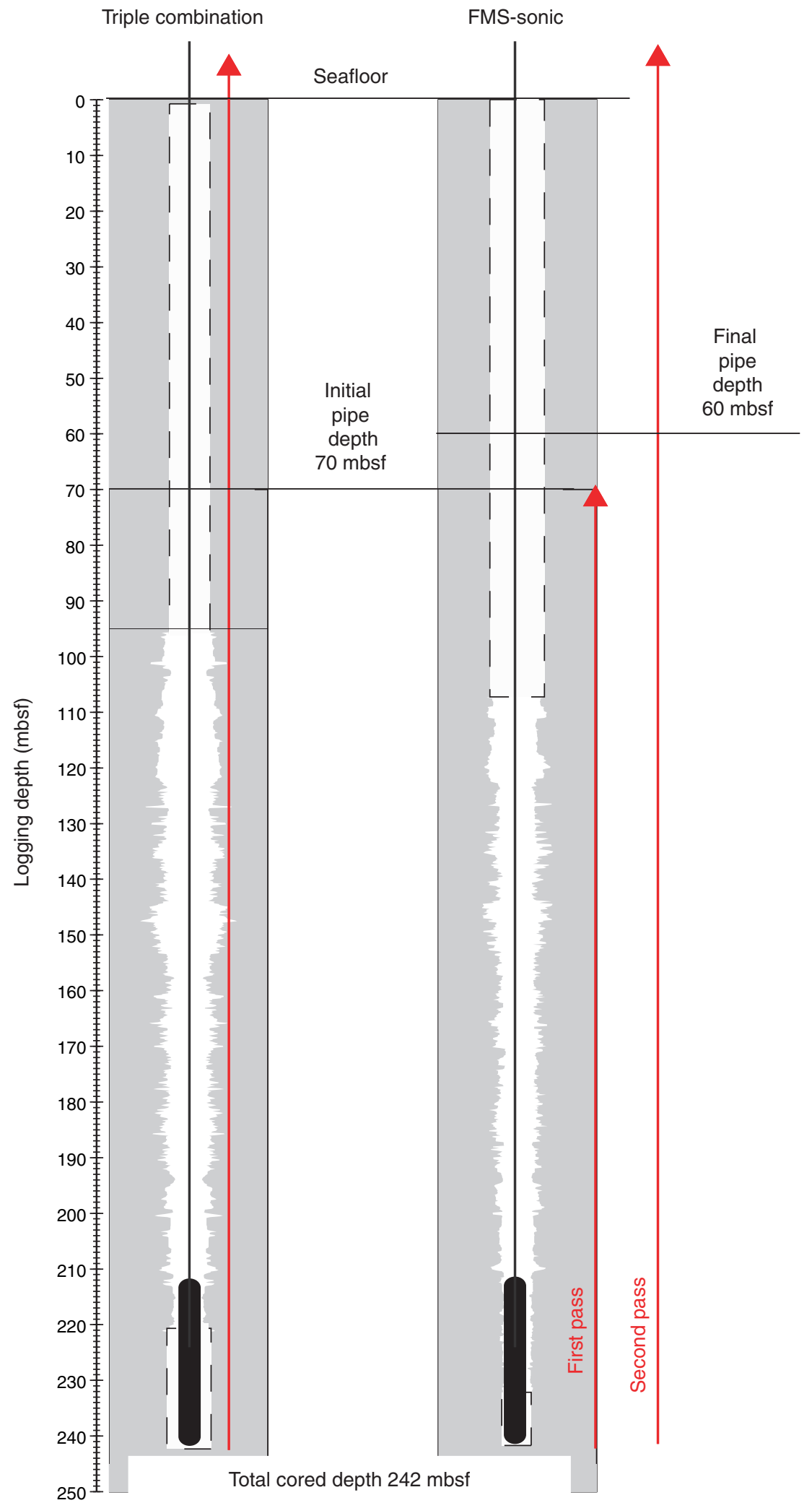


Figure F26. Quality control of the FMS-sonic tool string. Green = Pass 1 (first pass), red = Pass 2 (main pass). A. Caliper. B. Vertical tool acceleration $\left(A_{z}\right)$. C. Horizontal acceleration $\left(A_{x}\right)$. D. Horizontal acceleration $\left(A_{y}\right)$. E. Hole azimuth (HAZI) and orientation (P1AZ) for Pass 1. F. HAZI and P1AZ for Pass 2. G. Angular difference $(\Delta)$ in P1AZ between the two passes.

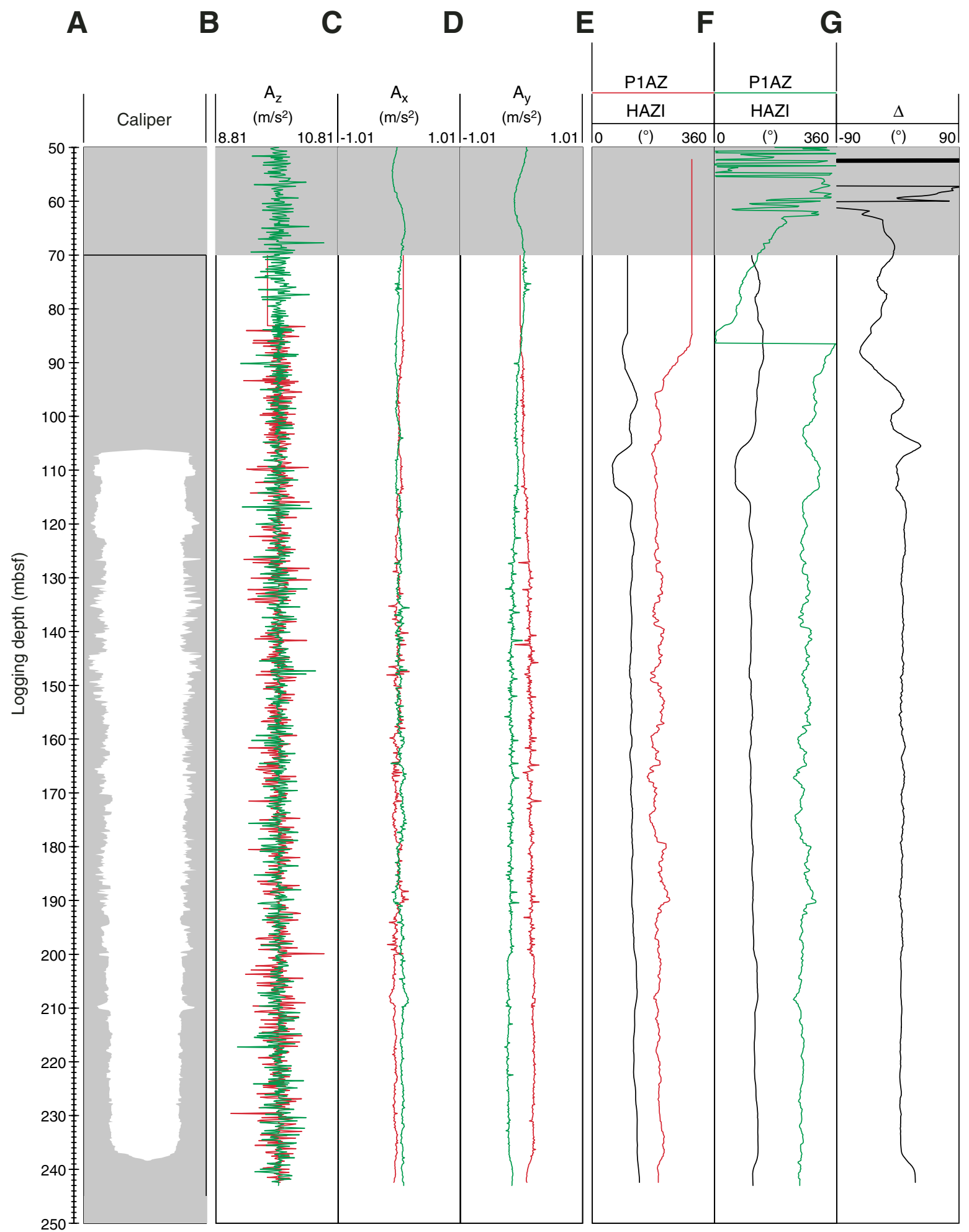


Figure F27. Depth matching. A. Triple combination (triple combo) total spectral gamma ray log (HSGR) used as reference for depth matching. B. Formation MicroScanner (FMS)-sonic tool string gamma ray log (ECGR) in respect to HSGR for Pass 1. C. FMS-sonic tool string ECGR in respect to HSGR for Pass 2.

A

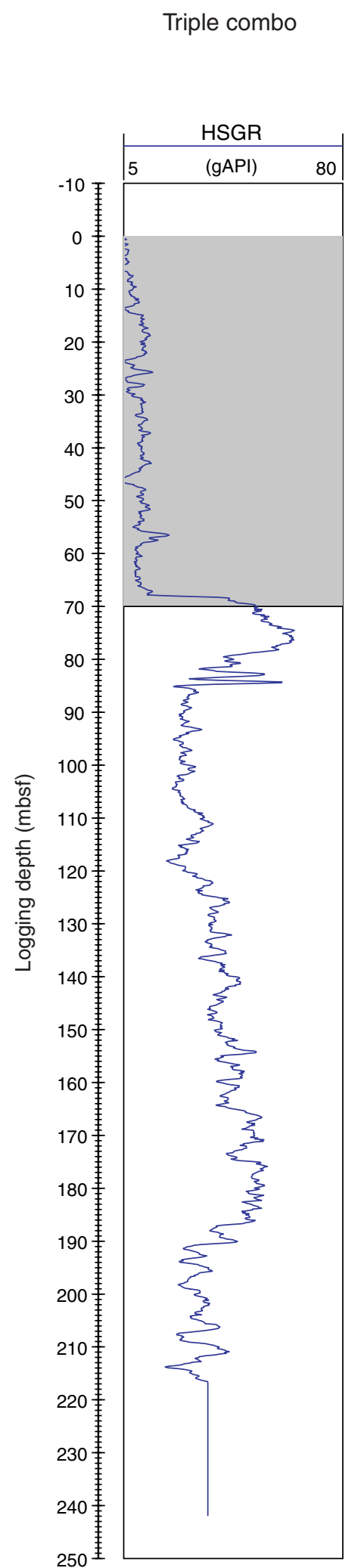

B

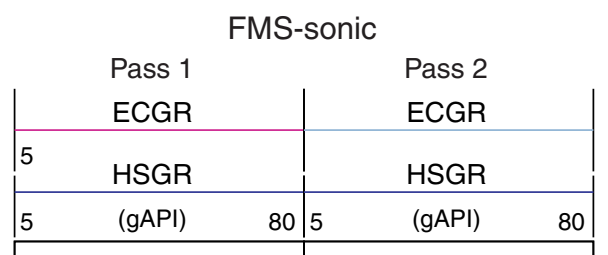

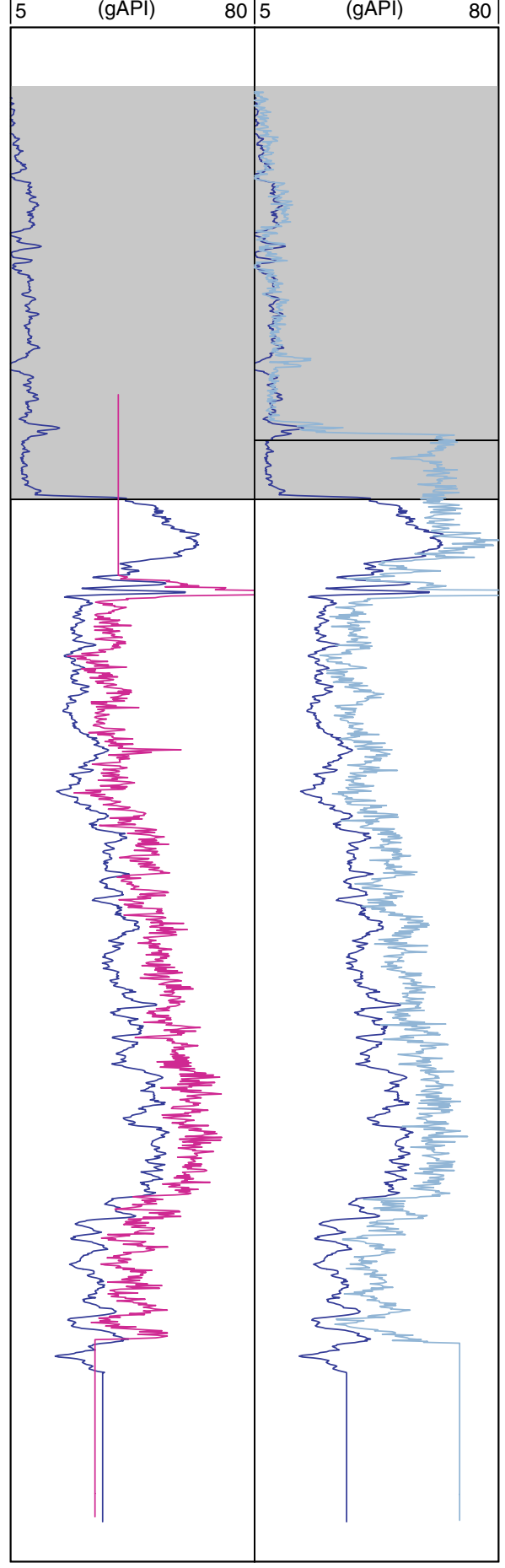


Figure F28. Logging stratigraphy. A. Hole shape, total spectral gamma ray, and potassium content. B. Thorium and uranium. C. Deep, medium, and shallow resistivities. D. Porosity and bulk density. E. Capture crosssection (SIGF) and photoelectric effect factor (PEF). F. Downhole compressional velocities. (N.B., jumps to higher values in Units 2 and 3 are invalid data.) G. Logging units.

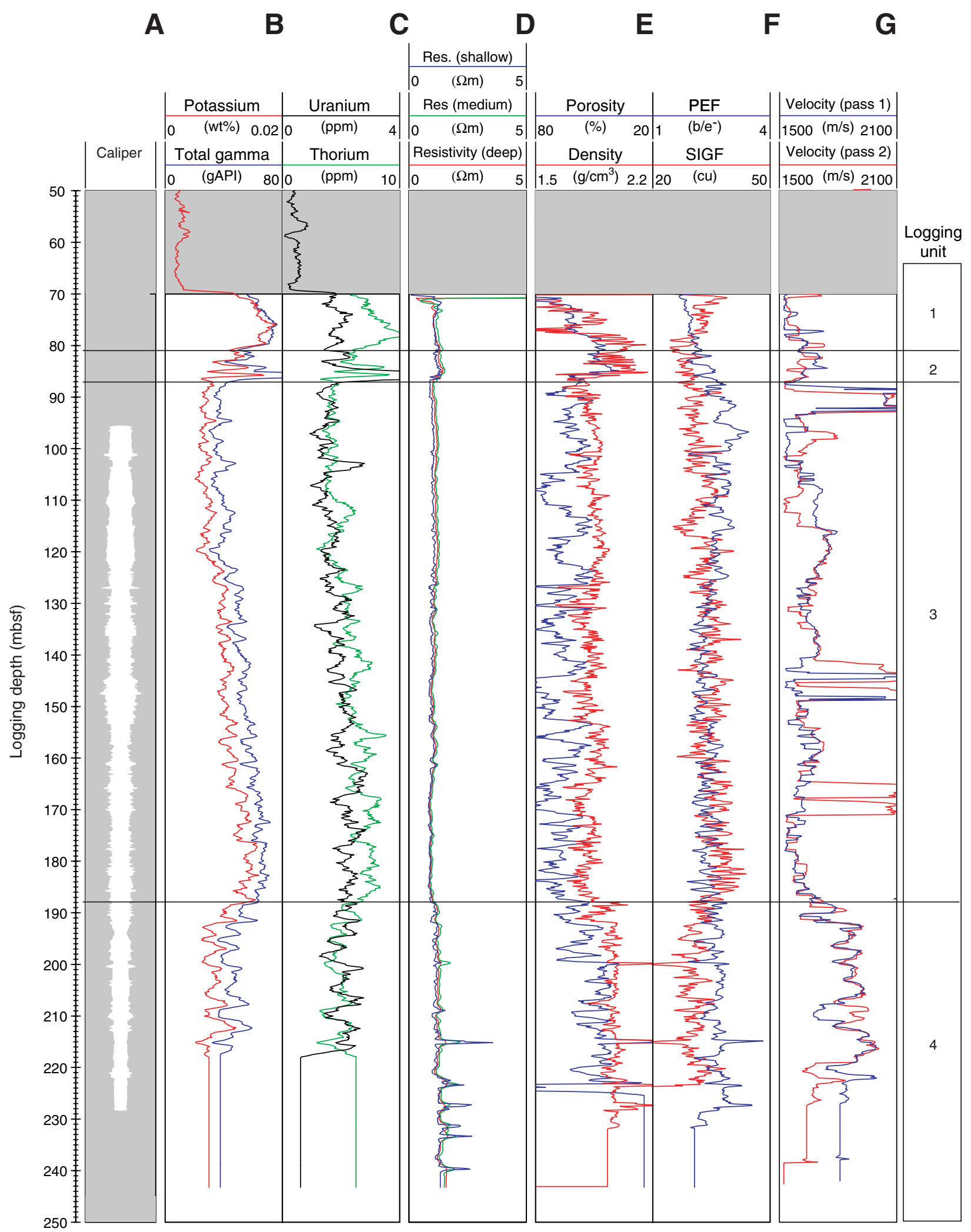


Figure F29. Slowness time coherence plots, showing examples of the problem encountered by the $P$-wave labelling algorithm in "slow" sediments, where the formation velocity approaches those of the drilling mud. Left panel shows original picking, right panel shows reprocessed picking. Black lines = wave labeling algorithm results.
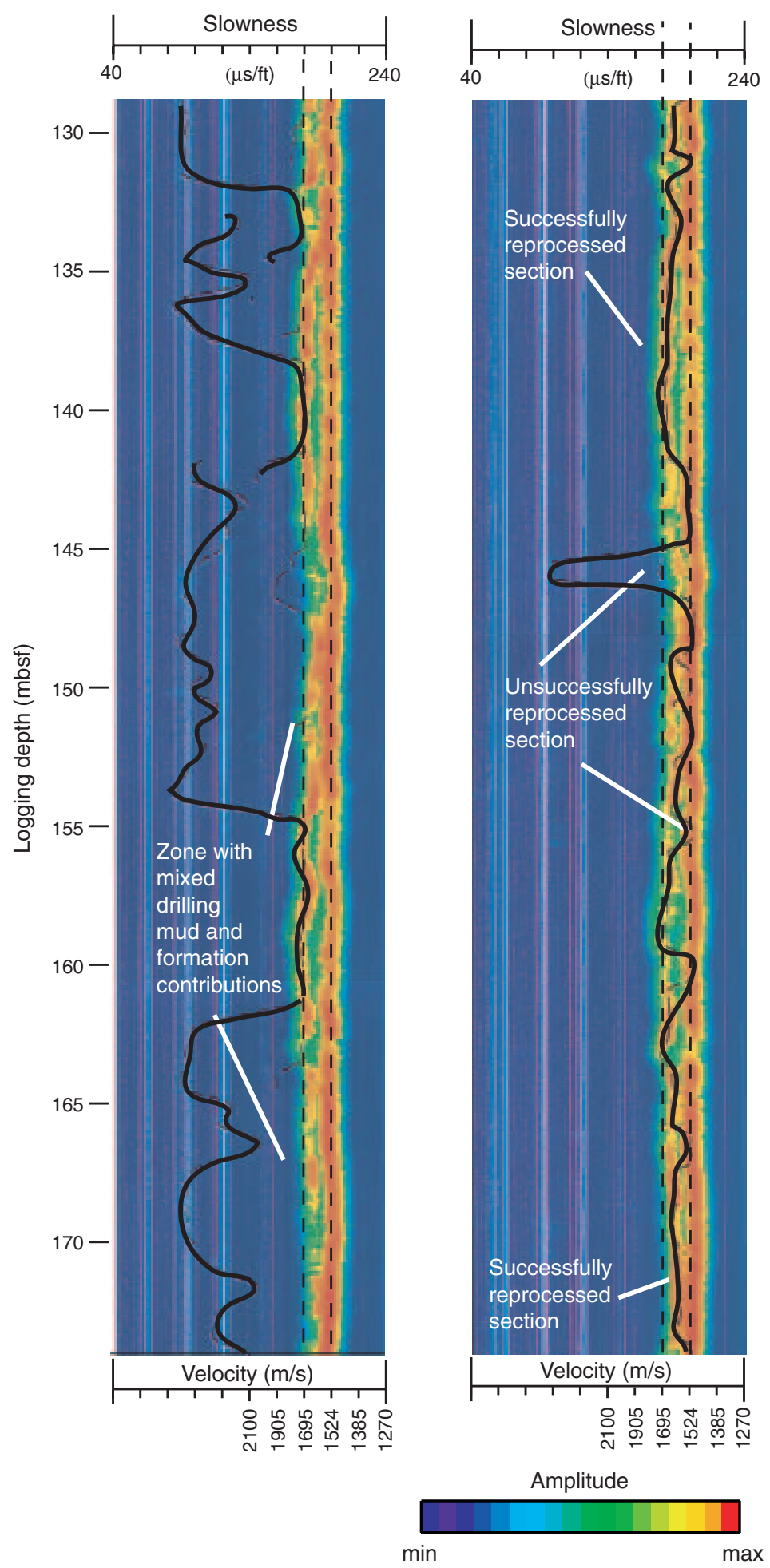
Figure F30. Core-log integration. Postcruise correlation between features recorded in these logs (especially acoustic, density, and gamma radiation) offer potential to provide in situ ground truth for core data. NGR = natural gamma radiation, HSGR $=$ total spectral gamma radiation, $\mathrm{MAD}=$ moisture and density, $\mathrm{APLC}=$ porosity, GRA = gamma ray attenuation, $\mathrm{RHOM}=$ bulk density, $\mathrm{PWL}=P$-wave logger, $\mathrm{PWS}=P$-wave sensor.

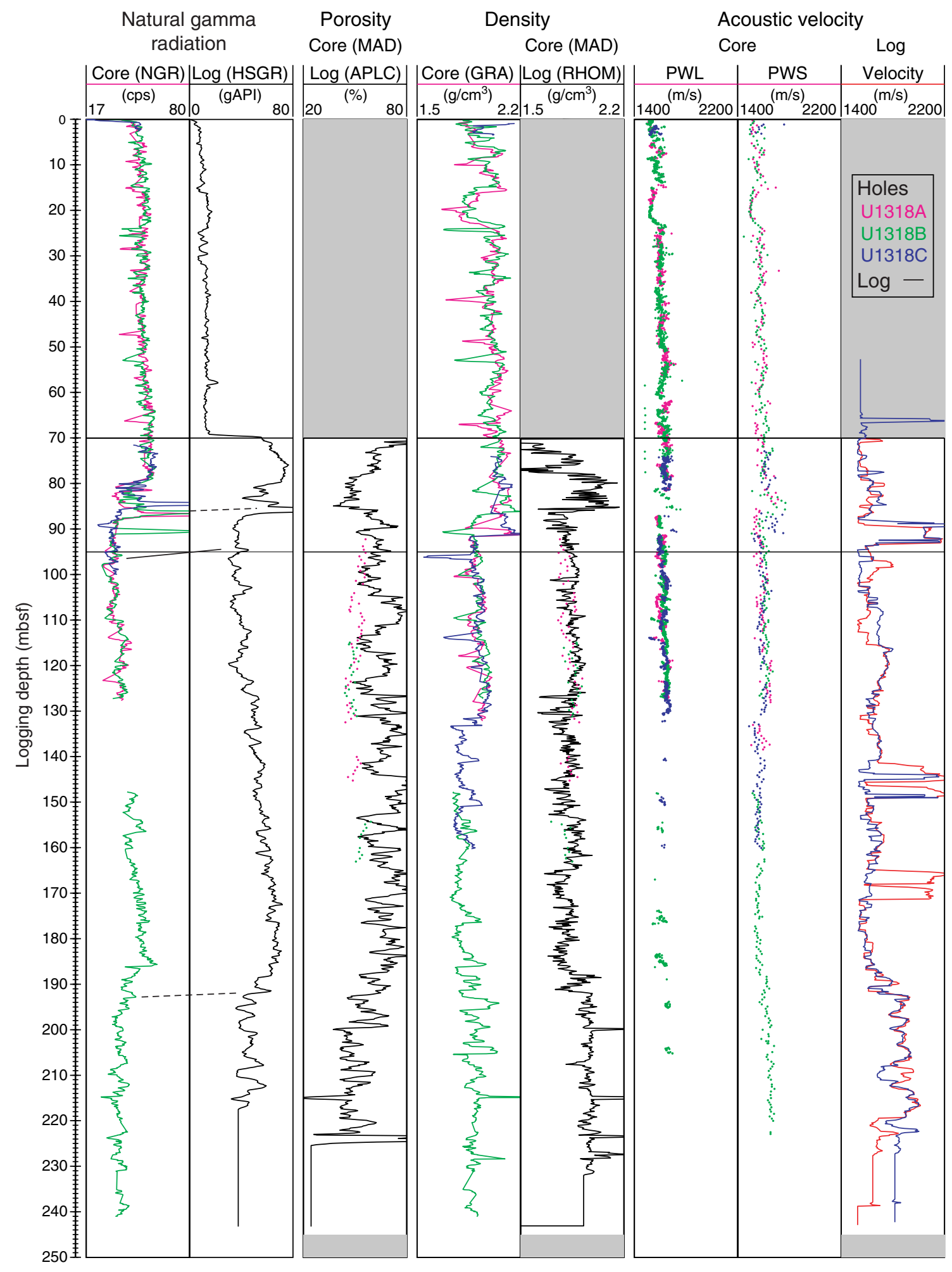


Table T1. Site U1318 coring summary. (Continued on next page.)

\section{Hole U1318A}

Latitude: $51^{\circ} 26.1616^{\prime} \mathrm{N}$

Longitude: $11^{\circ} 33.0184^{\prime} \mathrm{W}$

Seafloor (drill pipe measurement from rig floor; mbrf): 420.30

Distance between rig floor and sea level $(\mathrm{m}): 11.0$

Water depth (drill pipe measurement from sea level; $\mathrm{m}$ ): 409.3

Total depth (from rig floor; mbrf): 562.5

Total penetration (mbsf): 142.2

\section{Hole U1318B}

Latitude: $51^{\circ} 26.1480^{\prime} \mathrm{N}$

Longitude: $11^{\circ} 33.0186^{\prime} \mathrm{W}$

Seafloor (drill pipe measurement from rig floor; mbrf): 419.80

Distance between rig floor and sea level $(\mathrm{m}): 11.0$

Water depth (drill pipe measurement from sea level; $\mathrm{m}$ ): 408.8

Total depth (from rig floor; mbrf): 664.4

Total penetration (mbsf): 244.6

\section{Hole U1318C}

Latitude: $51^{\circ} 26.1497^{\prime} \mathrm{N}$

Longitude: $11^{\circ} 33.0400^{\prime} \mathrm{W}$

Seafloor (drill pipe measurement from rig floor; mbrf): 420.9

Distance between rig floor and sea level $(\mathrm{m}): 11.0$

Water depth (drill pipe measurement from sea level; m): 409.9

Total depth (from rig floor; mbrf): $\mathbf{5 7 5 . 4}$

Total penetration (mbsf): 154.5

\begin{tabular}{|c|c|c|c|c|c|c|c|c|}
\hline \multirow[b]{2}{*}{ Core } & \multirow{2}{*}{$\begin{array}{c}\text { Date } \\
\text { (May 2005) }\end{array}$} & \multirow[b]{2}{*}{ Local time } & \multicolumn{2}{|c|}{ Depth (mbsf) } & \multicolumn{2}{|c|}{ Length $(\mathrm{m})$} & \multirow{2}{*}{$\begin{array}{l}\text { Recovery } \\
\text { (\%) }\end{array}$} & \multirow[b]{2}{*}{ Comment } \\
\hline & & & Top & Bottom & Cored & Recovered & & \\
\hline \multicolumn{9}{|c|}{ 307-U1318A- } \\
\hline $1-\mathrm{H}$ & 8 & 2050 & 0.0 & 9.2 & 9.2 & 9.20 & 100.00 & \\
\hline $2-\mathrm{H}$ & 8 & 2140 & 9.2 & 18.7 & 9.5 & 9.94 & 104.63 & Start Tensor 1 at $2145 \mathrm{hr}$ \\
\hline $3-\mathrm{H}$ & 8 & 2305 & 18.7 & 28.2 & 9.5 & 9.95 & 104.74 & \\
\hline $4-\mathrm{H}$ & 8 & 2350 & 28.2 & 37.7 & 9.5 & 8.79 & 92.53 & \\
\hline $5-\mathrm{H}$ & 9 & 0020 & 37.7 & 47.2 & 9.5 & 9.10 & 95.79 & \\
\hline $6-\mathrm{H}$ & 9 & 0125 & 47.2 & 56.7 & 9.5 & 9.88 & 104.00 & Adara \\
\hline $7-\mathrm{H}$ & 9 & 0200 & 56.7 & 66.2 & 9.5 & 8.12 & 85.47 & \\
\hline $8-\mathrm{H}$ & 9 & 0235 & 66.2 & 75.7 & 9.5 & 7.55 & 79.47 & \\
\hline $9-\mathrm{H}$ & 9 & 0330 & 75.7 & 85.2 & 9.5 & 9.03 & 95.05 & \\
\hline $10-\mathrm{H}$ & 9 & 0405 & 85.2 & 94.7 & 9.5 & 9.09 & 95.68 & \\
\hline $11-\mathrm{H}$ & 9 & 0440 & 94.7 & 104.2 & 9.5 & 9.95 & 104.74 & \\
\hline $12-\mathrm{H}$ & 9 & 0535 & 104.2 & 113.7 & 9.5 & 8.35 & 87.89 & \\
\hline $13-\mathrm{H}$ & 9 & 0620 & 113.7 & 123.2 & 9.5 & 7.91 & 83.26 & \\
\hline $14-\mathrm{H}$ & 9 & 0725 & 123.2 & 132.7 & 9.5 & 5.06 & 53.26 & \\
\hline \multirow[t]{2}{*}{$15-\mathrm{H}$} & 9 & 0755 & 132.7 & 142.2 & 9.5 & 6.41 & 67.475 & Split liner \\
\hline & & & & Core totals: & 142.2 & 128.33 & 90.25 & \\
\hline \multicolumn{9}{|c|}{ 307-U1318B- } \\
\hline $1-\mathrm{H}$ & 9 & 1015 & 0.0 & 5.0 & 5.0 & 5.07 & 101.40 & \\
\hline $2-\mathrm{H}$ & 9 & 1040 & 5.0 & 14.5 & 9.5 & 9.33 & 98.21 & \\
\hline $3-\mathrm{H}$ & 9 & 1105 & 14.5 & 24.0 & 9.5 & 9.79 & 103.05 & Start Tensor 1 at $1040 \mathrm{hr}$ \\
\hline $4-\mathrm{H}$ & 9 & 1135 & 24.0 & 33.5 & 9.5 & 9.32 & 98.11 & \\
\hline $5-\mathrm{H}$ & 9 & 1205 & 33.5 & 43.0 & 9.5 & 9.78 & 102.95 & \\
\hline $6-\mathrm{H}$ & 9 & 1240 & 43.0 & 52.5 & 9.5 & 8.43 & 88.74 & \\
\hline $7-\mathrm{H}$ & 9 & 1310 & 52.5 & 62.0 & 9.5 & 9.46 & 99.58 & \\
\hline $8-\mathrm{H}$ & 9 & 1340 & 62.0 & 71.5 & 9.5 & 9.31 & 98.00 & \\
\hline $9-\mathrm{H}$ & 9 & 1415 & 71.5 & 81.0 & 9.5 & 8.16 & 85.89 & \\
\hline $10-\mathrm{H}$ & 9 & 1445 & 81.0 & 90.5 & 9.5 & 9.15 & 96.32 & \\
\hline $11-\mathrm{H}$ & 9 & 1515 & 90.5 & 100.0 & 9.5 & 7.73 & 81.37 & \\
\hline $12-\mathrm{H}$ & 9 & 1550 & 100.0 & 109.5 & 9.5 & 8.42 & 88.63 & \\
\hline $13-\mathrm{H}$ & 9 & 1620 & 109.5 & 119.0 & 9.5 & 8.35 & 87.89 & \\
\hline $14-\mathrm{H}$ & 9 & 1700 & 119.0 & 128.5 & 9.5 & 8.44 & 88.84 & \\
\hline $15-X$ & 9 & 1740 & 128.5 & 138.1 & 9.6 & 0.00 & 0.00 & \\
\hline $16-X$ & 9 & 1835 & 138.1 & 147.7 & 9.6 & 0.13 & 1.35 & \\
\hline $17-x$ & 9 & 1930 & 147.7 & 157.3 & 9.6 & 9.85 & 102.60 & \\
\hline $18-X$ & 9 & 2025 & 157.3 & 166.9 & 9.6 & 9.83 & 102.40 & \\
\hline $19-X$ & 9 & 2110 & 166.9 & 176.5 & 9.6 & 9.94 & 103.54 & \\
\hline $20-x$ & 9 & 2200 & 176.5 & 186.1 & 9.6 & 9.94 & 103.54 & \\
\hline $21-X$ & 9 & 2305 & 186.1 & 195.7 & 9.6 & 9.51 & 99.06 & \\
\hline $22-X$ & 9 & 0050 & 195.7 & 205.2 & 9.5 & 9.93 & 104.53 & \\
\hline $23-X$ & 10 & 0100 & 205.2 & 214.7 & 9.5 & 9.88 & 104.00 & \\
\hline
\end{tabular}


Table T1 (continued).

\begin{tabular}{|c|c|c|c|c|c|c|c|c|}
\hline Core & $\begin{array}{c}\text { Date } \\
\text { (May 2005) }\end{array}$ & Local time & \multicolumn{2}{|c|}{ Depth (mbsf) } & \multicolumn{3}{|r|}{$\begin{array}{l}\text { Recovery } \\
\text { (\%) }\end{array}$} & \multirow[t]{2}{*}{ Comment } \\
\hline \multicolumn{8}{|c|}{ 307-U1318B- } & \\
\hline $24-X$ & 10 & 0200 & 214.7 & 223.7 & 9.0 & 9.00 & 100.00 & \\
\hline $25-X$ & 10 & 0345 & 223.7 & 228.3 & 4.6 & 4.34 & 94.35 & \\
\hline $26-X$ & 10 & 0515 & 228.3 & 235.0 & 6.7 & 3.50 & 52.24 & \\
\hline \multirow[t]{2}{*}{$27-X$} & 10 & 0630 & 235.0 & 244.6 & 9.6 & 6.41 & 66.77 & \\
\hline & & & & Core totals: & 244.6 & 213.00 & 87.08 & \\
\hline \multicolumn{9}{|c|}{ 307-U1318C- } \\
\hline \multirow[t]{2}{*}{$1-\mathrm{H}$} & 10 & 2300 & 0.0 & 2.9 & 2.9 & 2.94 & 101.38 & \\
\hline & & $\star \star \star \star \star \star$ Drilled & rom 2.9 & o $70.0 \mathrm{mbsf}^{*}$ & & & & \\
\hline $2-\mathrm{H}$ & 11 & 0150 & 70.0 & 79.5 & 9.5 & 9.19 & 96.74 & \multirow[t]{10}{*}{ Tensor 1 started at $0115 \mathrm{hr}$} \\
\hline $3-\mathrm{H}$ & 11 & 0230 & 79.5 & 89.0 & 9.5 & 9.78 & 102.95 & \\
\hline $4-\mathrm{H}$ & 11 & 0310 & 89.0 & 98.5 & 9.5 & 8.63 & 90.84 & \\
\hline $5-\mathrm{H}$ & 11 & 0355 & 98.5 & 108.0 & 9.5 & 8.35 & 87.89 & \\
\hline $6-\mathrm{H}$ & 11 & 0430 & 108.0 & 117.5 & 9.5 & 7.58 & 79.79 & \\
\hline $7-\mathrm{H}$ & 11 & 0510 & 117.5 & 125.7 & 8.2 & 8.14 & 99.27 & \\
\hline $8-X$ & 11 & 0640 & 125.7 & 135.3 & 9.6 & 9.75 & 101.56 & \\
\hline $9-X$ & 11 & 0710 & 135.3 & 144.9 & 9.6 & 9.92 & 103.33 & \\
\hline \multirow[t]{2}{*}{$10-X$} & 11 & 0745 & 144.9 & 154.5 & 9.6 & 9.87 & 102.81 & \\
\hline & & & & Core totals: & 87.4 & 84.15 & 96.28 & \\
\hline
\end{tabular}


Table T2. Lithostratigraphic units, location in recovered cores, main lithology, and remarks, Site U1318.

\begin{tabular}{|c|c|c|c|c|c|c|c|c|c|c|c|c|c|}
\hline \multirow[b]{3}{*}{ Unit } & \multirow[b]{3}{*}{ Subunit } & \multicolumn{4}{|c|}{ Hole U1318A } & \multicolumn{4}{|c|}{ Hole U1318B } & \multicolumn{4}{|c|}{ Hole U1318C } \\
\hline & & \multicolumn{2}{|c|}{ Core, section, interval $(\mathrm{cm})$} & \multicolumn{2}{|c|}{ Depth (mbsf) } & \multicolumn{2}{|c|}{ Core, section, interval $(\mathrm{cm})$} & \multicolumn{2}{|c|}{ Depth (mbsf) } & \multicolumn{2}{|c|}{ Core, section, interval $(\mathrm{cm})$} & \multicolumn{2}{|c|}{ Depth (mbsf) } \\
\hline & & Top & Bottom & Top & Bottom & Top & Bottom & Top & Bottom & Top & Bottom & Top & Bottom \\
\hline \multirow[t]{3}{*}{1} & $1 \mathrm{~A}$ & $\begin{array}{l}\text { 307-U1318A- } \\
1 \mathrm{H}-1,0\end{array}$ & $\begin{array}{c}307-U 1318 \mathrm{~A}- \\
4 \mathrm{H}-5,24\end{array}$ & 0 & 33.3 & $\begin{array}{c}\text { 307-U1318B- } \\
1 \mathrm{H}-1,0\end{array}$ & $\begin{array}{l}\text { 307-U1318B- } \\
5 \mathrm{H}-2,2\end{array}$ & 0 & 35.03 & $\begin{array}{c}307-U 1318 C- \\
1 \mathrm{H}-1,0\end{array}$ & $\begin{array}{c}307-U 1318 C- \\
-\end{array}$ & 0 & - \\
\hline & 1B & $4 \mathrm{H}-5,24$ & $7 \mathrm{H}-3,60$ & 33.3 & 61.7 & $5 \mathrm{H}-2,2$ & $8 \mathrm{H}-1,0$ & 35.03 & 62 & - & - & - & - \\
\hline & $1 \mathrm{C}$ & $7 \mathrm{H}-3,60$ & $9 \mathrm{H}-3,22$ & 61.7 & 78.9 & $8 \mathrm{H}-1,0$ & $10 \mathrm{H}-1,100$ & 62 & 82 & - & $3 \mathrm{H}-1,45$ & - & 79.9 \\
\hline 2 & & $9 \mathrm{H}-4,0$ & $10 \mathrm{H}-2,0$ & 80.7 & 86.7 & $10 \mathrm{H}-1,100$ & $10 \mathrm{H}-4,72$ & 82 & 86.2 & $3 \mathrm{H}-1,45$ & $3 \mathrm{H}-4,18$ & 79.9 & 84.2 \\
\hline \multirow[t]{3}{*}{3} & $3 \mathrm{~A}$ & $10 \mathrm{H}-2,0$ & $14 \mathrm{H}-4,51$ & 86.7 & 128.3 & $10 \mathrm{H}-4,72$ & $14 \mathrm{H}-\mathrm{CC}, 16$ & 86.2 & 127.4 & $3 \mathrm{H}-4,18$ & $8 X-2,16$ & 84.2 & 127.3 \\
\hline & $3 B$ & $14 \mathrm{H}-4,51$ & - & 128.3 & - & $14 \mathrm{H}-\mathrm{CC}, 16$ & $21 X-3,114$ & 127.4 & 190.3 & $8 X-2,16$ & - & 127.3 & - \\
\hline & $3 C$ & - & - & - & - & $21 X-3,114$ & $27 \mathrm{X}-\mathrm{CC}, 29$ & 190.3 & 241 & - & - & - & - \\
\hline
\end{tabular}

$\begin{array}{lll}3 B & \text { Silty clays } & \text { contents, and color } \\ 3 C & \text { Massive throughout the subunit }\end{array}$

3C Silty clays to fine sands $\quad$ Sasive throughout the subunit 
Table T3. Calcareous nannofossil biostratigraphic data used for splice correlation, Hole U1318A.

\begin{tabular}{lc}
\hline \multicolumn{1}{c}{ Datum } & Age (Ma) \\
\hline FAD Emiliania huxleyi & 0.26 \\
LAD Pseudoemilinia lacunosa & 0.46 \\
ACM small Gephyrocapsa & 0.96 \\
LAD Helicosphaera sellii & 1.22 \\
LAD Calcidiscus macintyrei & 1.59 \\
LAD Sphenolithus spp. & 3.60 \\
LAD Reticulofenestra pseudoumbilica & 3.60 \\
LAD Discoaster bollii & 9.10 \\
FAD Cyclicargolithus floridanus & 13.24 \\
LAD Sphenolithus heteromorphus & 13.60 \\
LAD Helicosphaera ampliaperta & 15.60 \\
LAD Discoaster deflandrei & 16.24 \\
Discoaster exilis & Zone CN3-CN4 \\
\hline
\end{tabular}

Note: $F A D=$ first appearance datum, LAD = last appearance datum, $A C M=$ acme zone.

Table T4. Planktonic foraminifer biostratigraphic data used for splice correlation, Hole U1318A.

\begin{tabular}{llcc}
\hline \multicolumn{1}{c}{ Datum } & Core, section & $\begin{array}{c}\text { Depth } \\
(\mathrm{mbsf})\end{array}$ & $\begin{array}{c}\text { Age } \\
(\mathrm{Ma})\end{array}$ \\
\hline & $307-\mathrm{U} 1318 \mathrm{~A}-$ & & \\
FAD Globorotalia inflata & $9 \mathrm{H}-\mathrm{CC}$ & 112.5 & 3.20 \\
FAD Globorotalia crassaformis & $12 \mathrm{H}-\mathrm{CC}$ & 112.5 & 4.50 \\
LAD Praeorbulina circularis & $14 \mathrm{H}-\mathrm{CC}$ & 128.2 & 14.8 \\
\hline
\end{tabular}

Note: $F A D=$ first appearance datum, LAD = last appearance datum. 


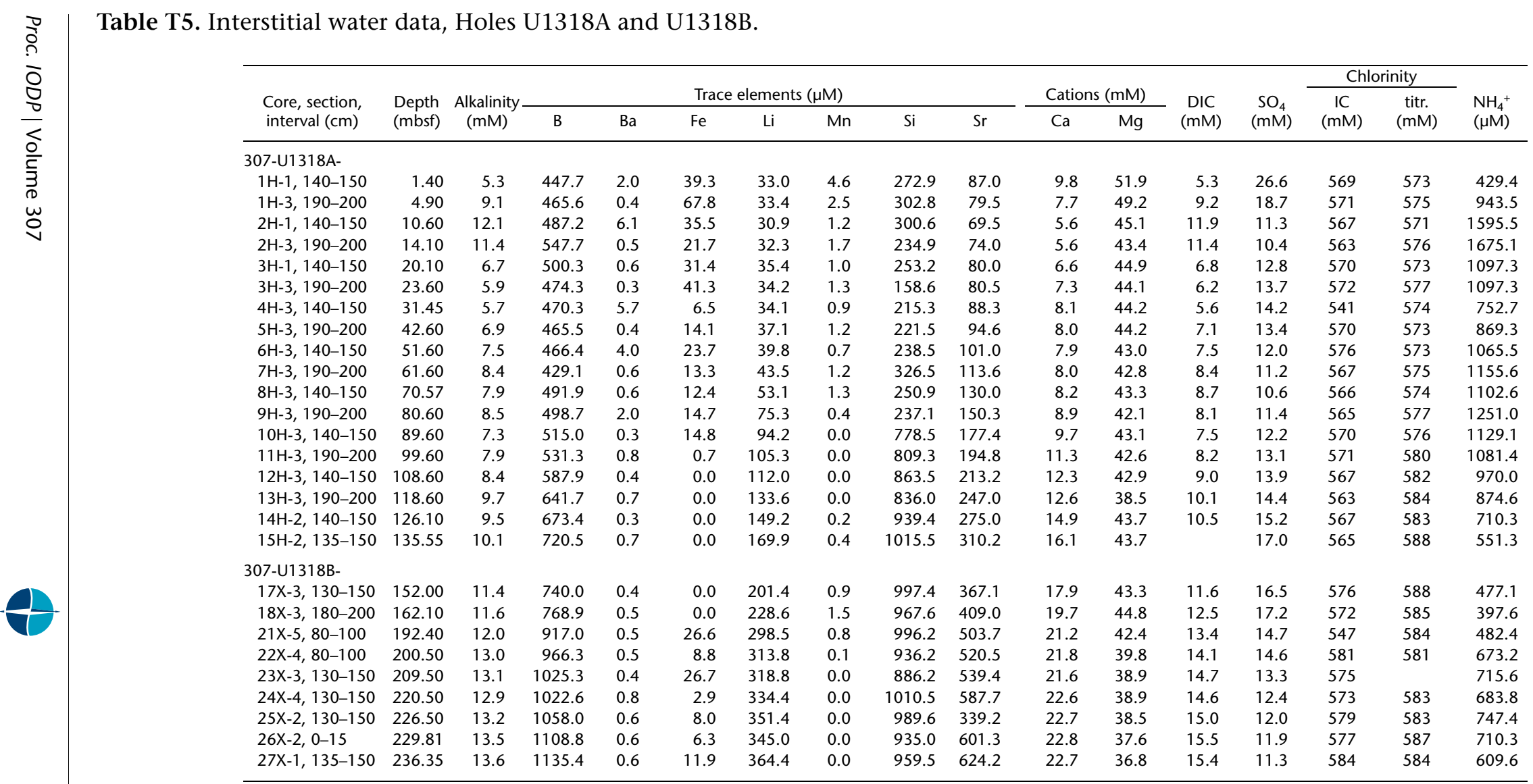

Notes: $\mathrm{DIC}=$ dissolved inorganic carbon, $I C=$ ion chromatograpy, titr. = titration. 
Table T6. Headspace gas, Holes U1318A and U1318B.

\begin{tabular}{|c|c|c|c|c|c|c|c|c|}
\hline $\begin{array}{l}\text { Core, section, } \\
\text { interval }(\mathrm{cm})\end{array}$ & $\begin{array}{l}\text { Depth } \\
\text { (mbsf) }\end{array}$ & $\begin{array}{l}\text { HS weight } \\
\text { (g) }\end{array}$ & $\begin{array}{l}\text { Analytical } \\
\text { weight (g) }\end{array}$ & $\begin{array}{l}\text { Safety } \mathrm{CH}_{4} \\
\quad(\mathrm{ppm})\end{array}$ & $\begin{array}{l}\text { Safety } \mathrm{C}_{2} \mathrm{H}_{6} \\
\quad(\mathrm{ppm})\end{array}$ & $\begin{array}{l}\text { Dissolved } \mathrm{CH}_{4} \\
(\mu \mathrm{M})\end{array}$ & $\begin{array}{l}\text { Adsorbed } \mathrm{CH}_{4} \\
(\mu \mathrm{mol} / \mathrm{g})\end{array}$ & $\begin{array}{c}\text { Dissolved } \mathrm{C}_{2} \mathrm{H}_{6} \\
(\mu \mathrm{M})\end{array}$ \\
\hline \multicolumn{9}{|l|}{ 307-U1318A- } \\
\hline $1 \mathrm{H}-1,135-140$ & 1.35 & 7.41 & 10.70 & 2.30 & 0.00 & 0.433 & 0.012 & 0.000 \\
\hline $1 \mathrm{H}-4,0-5$ & 5.00 & 5.90 & ND & 2.20 & 0.00 & ND & ND & ND \\
\hline $2 \mathrm{H}-2,0-5$ & 10.70 & 6.54 & 11.00 & 2.30 & 0.00 & 0.474 & 0.000 & 0.000 \\
\hline $3 \mathrm{H}-2,0-5$ & 20.20 & 7.82 & 10.35 & 1.90 & 0.00 & 0.640 & 0.042 & 0.000 \\
\hline $4 \mathrm{H}-4,0-5$ & 31.55 & 4.84 & 11.14 & 1.80 & 0.00 & 0.500 & 0.000 & 0.000 \\
\hline $5 \mathrm{H}-4,0-5$ & 42.70 & 10.15 & 10.50 & 2.10 & 0.00 & 0.413 & 0.023 & 0.000 \\
\hline $6 \mathrm{H}-4,0-5$ & 51.70 & 9.43 & 12.95 & 2.00 & 0.00 & 0.434 & 0.012 & 0.000 \\
\hline $7 \mathrm{H}-4,0-5$ & 61.70 & 9.31 & 11.90 & 2.00 & 0.00 & 0.524 & 0.019 & 0.000 \\
\hline $8 \mathrm{H}-4,0-5$ & 70.67 & 6.94 & 11.62 & 1.70 & 0.00 & 0.483 & 0.008 & 0.000 \\
\hline $9 \mathrm{H}-4,0-5$ & 80.70 & 5.85 & 13.39 & 1.60 & 0.00 & 0.231 & 0.000 & 0.000 \\
\hline $10 \mathrm{H}-4,0-5$ & 89.70 & 8.12 & 10.22 & 2.00 & 0.00 & 0.000 & 0.000 & 0.000 \\
\hline $11 \mathrm{H}-4,0-5$ & 99.70 & 8.99 & 10.37 & 2.10 & 0.00 & 0.307 & 0.009 & 0.000 \\
\hline $12 \mathrm{H}-4,0-5$ & 108.70 & 4.91 & 9.52 & 1.90 & 0.00 & 0.396 & 0.000 & 0.000 \\
\hline $13 \mathrm{H}-4,0-5$ & 118.70 & 8.31 & 10.66 & 2.20 & 0.00 & 0.576 & 0.024 & 0.086 \\
\hline $14 \mathrm{H}-3,0-5$ & 126.20 & 5.96 & 11.22 & 2.10 & 0.00 & 0.664 & 0.014 & 0.129 \\
\hline $15 \mathrm{H}-3,0-5$ & 135.70 & 5.66 & 10.97 & 2.00 & 0.00 & 0.743 & 0.019 & 0.144 \\
\hline \multicolumn{9}{|l|}{ 307-U1318B- } \\
\hline $17 X-3,125-130$ & 151.95 & 5.40 & ND & 1.50 & 0.00 & ND & ND & ND \\
\hline $18 X-3,175-180$ & 162.05 & 7.62 & 9.80 & 2.10 & 0.00 & 5.477 & 0.531 & 0.118 \\
\hline $19 X-3,75-80$ & 170.65 & 6.20 & 9.85 & 2.60 & 0.00 & 0.348 & 0.000 & 0.058 \\
\hline $20 X-3,75-80$ & 180.25 & 7.09 & 8.46 & 2.20 & 0.00 & 1.414 & 0.138 & 0.052 \\
\hline $21 X-5,75-80$ & 192.35 & 8.15 & 9.99 & 2.90 & 0.00 & 0.500 & 0.019 & 0.076 \\
\hline $22 X-4,75-80$ & 200.45 & 7.19 & 9.58 & 2.60 & 0.00 & 0.577 & 0.014 & ND \\
\hline $23 X-3,125-130$ & 209.45 & 5.89 & 9.19 & 1.90 & 0.00 & 0.460 & 0.003 & 0.080 \\
\hline $24 X-4,125-130$ & 220.45 & 7.55 & 9.64 & 2.90 & 0.00 & 0.719 & 0.029 & 0.139 \\
\hline $25 X-2,125-130$ & 226.45 & 7.97 & 11.39 & 2.80 & 0.00 & 0.719 & 0.027 & 0.155 \\
\hline $26 X-2,15-20$ & 229.96 & 6.83 & 10.03 & 2.70 & 0.00 & 1.324 & 0.084 & 0.157 \\
\hline $27 X-1,130-135$ & 236.30 & 7.56 & 10.37 & 3.70 & 0.70 & 37.783 & 3.589 & 0.275 \\
\hline
\end{tabular}

Notes: $\mathrm{HS}=$ headspace. ND = not determined. 
Table T7. Carbon, Holes U1318A and U1318B.

\begin{tabular}{|c|c|c|c|}
\hline \multirow{2}{*}{$\begin{array}{l}\text { Core, section, } \\
\text { interval }(\mathrm{cm})\end{array}$} & \multirow{2}{*}{$\begin{array}{l}\text { Depth } \\
\text { (mbsf) }\end{array}$} & \multicolumn{2}{|c|}{ Carbon (wt \%) } \\
\hline & & Inorganic & $\mathrm{CaCO}_{3}$ \\
\hline \multicolumn{4}{|l|}{ 307-U1318A- } \\
\hline $1 \mathrm{H}-2,24-25$ & 1.74 & 2.1 & 17.6 \\
\hline $1 \mathrm{H}-5,25-26$ & 6.75 & 2.2 & 18.2 \\
\hline $2 \mathrm{H}-2,18-19$ & 10.88 & 2.1 & 17.8 \\
\hline $2 \mathrm{H}-5,25-26$ & 15.95 & 2.2 & 18.0 \\
\hline $2 \mathrm{H}-5,75-76$ & 16.45 & 2.0 & 16.3 \\
\hline $3 \mathrm{H}-2,103-104$ & 21.23 & 1.8 & 14.6 \\
\hline $3 \mathrm{H}-5,11-12$ & 25.31 & 3.1 & 25.7 \\
\hline $4 \mathrm{H}-2,25-26$ & 28.80 & 2.1 & 17.7 \\
\hline $4 \mathrm{H}-5,17-18$ & 33.22 & 1.6 & 13.7 \\
\hline $5 \mathrm{H}-2,86-87$ & 40.06 & 1.8 & 15.2 \\
\hline $5 \mathrm{H}-5,83-84$ & 45.03 & 1.8 & 15.2 \\
\hline $6 \mathrm{H}-2,23-24$ & 48.93 & 2.3 & 19.2 \\
\hline $6 \mathrm{H}-5,23-24$ & 53.43 & 1.7 & 14.5 \\
\hline $7 \mathrm{H}-2,50-51$ & 58.70 & 2.0 & 16.4 \\
\hline $7 \mathrm{H}-5,50-51$ & 63.70 & 1.6 & 13.5 \\
\hline $8 \mathrm{H}-2,22-23$ & 67.89 & 1.6 & 13.6 \\
\hline $8 \mathrm{H}-5,22-23$ & 72.39 & 1.6 & 13.5 \\
\hline $9 \mathrm{H}-2,27-28$ & 77.47 & 2.0 & 16.3 \\
\hline $9 \mathrm{H}-5,110-111$ & 83.30 & 2.3 & 18.9 \\
\hline $10 \mathrm{H}-2,43-44$ & 87.13 & 5.0 & 42.0 \\
\hline $10 \mathrm{H}-5,30-31$ & 91.50 & 5.5 & 45.6 \\
\hline $11 \mathrm{H}-2,31-32$ & 96.51 & 4.3 & 35.9 \\
\hline $11 \mathrm{H}-5,27-28$ & 101.47 & 4.6 & 38.3 \\
\hline $12 \mathrm{H}-2,24-25$ & 105.94 & 5.7 & 47.0 \\
\hline $12 \mathrm{H}-5,24-25$ & 110.44 & 4.8 & 39.6 \\
\hline $13 \mathrm{H}-2,76-77$ & 115.96 & 4.9 & 40.8 \\
\hline $13 \mathrm{H}-4,76-77$ & 119.46 & 4.5 & 37.2 \\
\hline $14 \mathrm{H}-1,76-77$ & 123.96 & 3.4 & 28.3 \\
\hline $14 \mathrm{H}-3,71-72$ & 126.91 & 4.2 & 35.0 \\
\hline $15 \mathrm{H}-2,24-25$ & 134.44 & 2.4 & 19.8 \\
\hline \multicolumn{4}{|l|}{ 307-U1318B- } \\
\hline $13 \mathrm{H}-2,17-18$ & 111.17 & 4.3 & 35.7 \\
\hline $13 \mathrm{H}-5,99-100$ & 116.49 & 6.0 & 50.2 \\
\hline $14 \mathrm{H}-2,18-19$ & 120.68 & 3.3 & 27.3 \\
\hline $14 \mathrm{H}-4,18-19$ & 123.68 & 4.2 & 34.5 \\
\hline $17 X-2,23-24$ & 149.43 & 2.5 & 21.0 \\
\hline $17 X-5,23-24$ & 153.93 & 2.1 & 17.7 \\
\hline $18 X-3,24-25$ & 160.54 & 2.6 & 21.8 \\
\hline $18 X-5,24-25$ & 164.04 & 2.3 & 19.0 \\
\hline $19 X-2,25-26$ & 168.65 & 1.3 & 11.0 \\
\hline $19 X-5,31-32$ & 172.21 & 1.4 & 11.5 \\
\hline $20 X-2,37-38$ & 178.37 & 1.2 & 9.8 \\
\hline $20 X-5,21-22$ & 181.71 & 1.4 & 11.9 \\
\hline $21 X-2,30-31$ & 187.90 & 1.9 & 15.6 \\
\hline $21 X-5,48-49$ & 192.08 & 2.8 & 23.1 \\
\hline $23 X-2,27-28$ & 206.97 & 3.0 & 25.0 \\
\hline $23 X-2,27-28$ & 206.97 & 2.5 & 20.5 \\
\hline $23 X-5,25-26$ & 211.45 & 2.7 & 22.3 \\
\hline $23 X-5,28-29$ & 211.48 & 3.2 & 26.6 \\
\hline $24 X-1,15-16$ & 214.85 & 8.4 & 69.8 \\
\hline $24 X-3,25-26$ & 217.95 & 3.2 & 26.4 \\
\hline $25 X-1,7-8$ & 223.77 & 8.6 & 71.7 \\
\hline $25 X-3,25-26$ & 226.95 & 3.6 & 29.5 \\
\hline $27 X-1,100-101$ & 236.00 & 4.2 & 35.0 \\
\hline $27 X-4,24-25$ & 239.74 & 4.1 & 33.7 \\
\hline
\end{tabular}


Table T8. Contamination test results from the use of perfluorcarbon tracer and fluorescent microspheres, Holes U1318A and U1318B.

\begin{tabular}{|c|c|c|c|c|c|c|}
\hline Core, section & Depth (mbsf) & PFC-out & PFC-in & Catwalk & Drill fluid & $\begin{array}{l}\text { Fluorescent } \\
\text { microspheres }\end{array}$ \\
\hline \multicolumn{7}{|l|}{ 307-U1318A- } \\
\hline $1 \mathrm{H} 3$ & $4.85-4.90$ & ND & ND & - & - & 0 \\
\hline $2 \mathrm{H}-3$ & $14.05-14.10$ & ND & ND & - & - & 0 \\
\hline $3 \mathrm{H}-3$ & $23.55-23.60$ & ND & ND & - & - & 2425 \\
\hline $5 \mathrm{H}-3$ & $42.50-42.55$ & ND & ND & - & Positive & 0 \\
\hline $6 \mathrm{H}-3$ & $51.50-51.55$ & ND & ND & - & - & 0 \\
\hline 7H-3 & $61.50-61.55$ & ND & ND & ND & - & 0 \\
\hline $8 \mathrm{H}-3$ & $70.47-70.52$ & ND & ND & ND & - & 0 \\
\hline $9 \mathrm{H}-3$ & $80.50-80.55$ & Positive & ND & ND & - & 0 \\
\hline $10 \mathrm{H}-3$ & $89.50-89.55$ & ND & ND & - & - & 0 \\
\hline $11 \mathrm{H}-3$ & $99.50-99.55$ & Positive & ND & ND & - & 20 \\
\hline $12 \mathrm{H}-3$ & 108.50-108.55 & Positive & ND & - & - & 0 \\
\hline $13 \mathrm{H}-3$ & 118.50-118.55 & Positive & ND & ND & - & 18 \\
\hline \multicolumn{7}{|l|}{ 307-U1318B- } \\
\hline $17 X-3$ & 151.95-152.00 & - & ND & - & - & \\
\hline $18 X-3$ & $162.05-162.10$ & ND & ND & ND & Positive & 0 \\
\hline $19 X-4$ & $171.65-171.70$ & ND & ND & - & Positive & 0 \\
\hline $20 X-4$ & $181.25-181.30$ & ND & ND & - & - & 0 \\
\hline $21 X-5$ & $192.35-192.40$ & ND & ND & - & - & 16 \\
\hline $22 X-4$ & $200.45-200.50$ & ND & ND & - & - & 0 \\
\hline $23 X-3$ & 209.45-209.50 & ND & ND & ND & - & 782 \\
\hline $24 X-4$ & $220.45-220.50$ & ND & ND & - & - & 0 \\
\hline $25 X-2$ & $226.45-226.50$ & ND & ND & - & - & 0 \\
\hline $26 X-2$ & $229.96-230.01$ & ND & ND & - & - & 0 \\
\hline $27 X-1$ & $236.30-236.35$ & ND & ND & - & - & 0 \\
\hline
\end{tabular}

Notes: $\mathrm{PFC}$-out $=$ sample from the core periphery (interface between liner and core), PFC-in = sample from the inner core section between center and periphery. $-=$ no sample taken, ND = no detection. 
Table T9. Composite depth offsets, Holes U1318A, U1318B, and U1318C.

\begin{tabular}{|c|c|c|c|c|}
\hline Core & $\begin{array}{l}\text { Length } \\
(\mathrm{m})\end{array}$ & $\begin{array}{l}\text { Depth } \\
\text { (mbsf) }\end{array}$ & $\begin{array}{l}\text { Offset } \\
\text { (m) }\end{array}$ & $\begin{array}{l}\text { Depth } \\
\text { (mcd) }\end{array}$ \\
\hline \multicolumn{5}{|c|}{ 307-U1318A- } \\
\hline $1 \mathrm{H}$ & 9.2 & 0 & -0.36 & -0.36 \\
\hline $2 \mathrm{H}$ & 9.5 & 9.2 & -0.06 & 9.14 \\
\hline $3 \mathrm{H}$ & 9.5 & 18.7 & 0.79 & 19.49 \\
\hline $4 \mathrm{H}$ & 9.5 & 28.2 & 1.94 & 30.14 \\
\hline $5 \mathrm{H}$ & 9.5 & 37.7 & 1.91 & 39.61 \\
\hline $6 \mathrm{H}$ & 9.5 & 47.2 & 1.31 & 48.51 \\
\hline $7 \mathrm{H}$ & 9.5 & 56.7 & 1.86 & 58.56 \\
\hline $8 \mathrm{H}$ & 9.5 & 66.2 & 2.59 & 68.79 \\
\hline $9 \mathrm{H}$ & 9.5 & 75.7 & 2.51 & 78.21 \\
\hline $10 \mathrm{H}$ & 9.5 & 85.2 & 2.65 & 87.85 \\
\hline $11 \mathrm{H}$ & 9.5 & 94.7 & 2.46 & 97.16 \\
\hline $12 \mathrm{H}$ & 9.5 & 104.2 & 2.41 & 106.61 \\
\hline $13 \mathrm{H}$ & 9.5 & 113.7 & 2.21 & 115.91 \\
\hline $14 \mathrm{H}$ & 9.5 & 123.2 & 2.89 & 126.09 \\
\hline $15 \mathrm{H}$ & 9.5 & 132.7 & 2.89 & 135.59 \\
\hline \multicolumn{5}{|c|}{ 307-U1318B- } \\
\hline $1 \mathrm{H}$ & 5 & 0 & 0 & 0 \\
\hline $2 \mathrm{H}$ & 9.5 & 5 & -0.31 & 4.69 \\
\hline $3 \mathrm{H}$ & 9.5 & 14.5 & 0.69 & 15.19 \\
\hline $4 \mathrm{H}$ & 9.5 & 24 & 0.54 & 24.54 \\
\hline $5 \mathrm{H}$ & 9.5 & 33.5 & 0.29 & 33.79 \\
\hline $6 \mathrm{H}$ & 9.5 & 43 & 1.31 & 44.31 \\
\hline $7 \mathrm{H}$ & 9.5 & 52.5 & 1.61 & 54.11 \\
\hline $8 \mathrm{H}$ & 9.5 & 62 & 1.96 & 63.96 \\
\hline $9 \mathrm{H}$ & 9.5 & 71.5 & 1.96 & 73.46 \\
\hline $10 \mathrm{H}$ & 9.5 & 81 & 1.96 & 82.96 \\
\hline $11 \mathrm{H}$ & 9.5 & 90.5 & 1.96 & 92.46 \\
\hline $12 \mathrm{H}$ & 9.5 & 100 & 2.61 & 102.61 \\
\hline $13 \mathrm{H}$ & 9.5 & 109.5 & 3.26 & 112.76 \\
\hline $14 \mathrm{H}$ & 9.5 & 119 & 2.84 & 121.84 \\
\hline $15 X$ & 9.6 & 128.5 & 2.84 & 131.34 \\
\hline $16 X$ & 9.6 & 138.1 & 2.84 & 140.94 \\
\hline $17 X$ & 9.6 & 147.7 & 3.14 & 150.84 \\
\hline $18 X$ & 9.6 & 157.3 & 3.14 & 160.44 \\
\hline $19 x$ & 9.6 & 166.9 & 3.14 & 170.04 \\
\hline $20 x$ & 9.6 & 176.5 & 3.14 & 179.64 \\
\hline $21 x$ & 9.6 & 186.1 & 3.14 & 189.24 \\
\hline $22 X$ & 9.5 & 195.7 & 3.14 & 198.84 \\
\hline $23 x$ & 9.5 & 205.2 & 3.14 & 208.34 \\
\hline $24 X$ & 9 & 214.7 & 3.14 & 217.84 \\
\hline $25 X$ & 4.6 & 223.7 & 3.14 & 226.84 \\
\hline $26 X$ & 6.7 & 228.3 & 3.14 & 231.44 \\
\hline $27 X$ & 9.6 & 235 & 3.14 & 238.14 \\
\hline \multicolumn{5}{|c|}{ 307-U1318C- } \\
\hline $1 \mathrm{H}$ & 2.9 & & & \\
\hline $2 \mathrm{H}$ & 9.5 & 70 & 3.46 & 73.46 \\
\hline $3 \mathrm{H}$ & 9.5 & 79.5 & 5.06 & 84.56 \\
\hline $4 \mathrm{H}$ & 9.5 & 89 & 4.95 & 93.95 \\
\hline $5 \mathrm{H}$ & 9.5 & 98.5 & 4.95 & 103.45 \\
\hline $6 \mathrm{H}$ & 9.5 & 108 & 4.11 & 112.11 \\
\hline $7 \mathrm{H}$ & 8.2 & 117.5 & 4.11 & 121.61 \\
\hline $8 x$ & 9.6 & 125.7 & 4.44 & 130.14 \\
\hline $9 X$ & 9.6 & 135.3 & 4.44 & 139.74 \\
\hline $10 x$ & 9.6 & 144.9 & 4.44 & 149.34 \\
\hline
\end{tabular}


Table T10. Splice tie points, Site U1318.

\begin{tabular}{|c|c|c|c|c|c|c|}
\hline \multirow{2}{*}{$\begin{array}{l}\text { Hole, core, section, } \\
\text { interval }(\mathrm{cm})\end{array}$} & \multicolumn{2}{|c|}{ Depth } & & \multirow{2}{*}{$\begin{array}{l}\text { Hole, core, section, } \\
\text { interval }(\mathrm{cm})\end{array}$} & \multicolumn{2}{|c|}{ Depth } \\
\hline & (mbsf) & (mcd) & & & (mbsf) & (mcd) \\
\hline \multicolumn{7}{|l|}{$307-$} \\
\hline U1318B-1H-4, 70 & 4.7 & 4.7 & Tie to & U1318A-1H-4, 4 & 5.06 & 4.7 \\
\hline U1318A-1H-5, 90 & 7.4 & 7.04 & Tie to & U1318B-2H-2, 85 & 7.35 & 7.04 \\
\hline U1318B-2H-6, 145 & 13.95 & 13.64 & Tie to & U1318A-2H-3, 100 & 13.7 & 13.64 \\
\hline U1318A-2H-5, 60 & 16.3 & 16.24 & Tie to & U1318B-3H-1, 105 & 15.55 & 16.24 \\
\hline U1318B-3H-7, 30 & 23.8 & 24.49 & Tie to & U1318A-3H-3, 150 & 23.7 & 24.49 \\
\hline U1318A-3H-6, 25 & 26.95 & 27.74 & Tie to & U1318B-4H-3, 20 & 27.2 & 27.74 \\
\hline U1318B-4H-6, 55 & 32.05 & 32.59 & Tie to & U1318A-4H-3, 60 & 30.65 & 32.59 \\
\hline U1318A-4H-5, 90 & 33.95 & 35.89 & Tie to & U1318B-5H-2, 60 & 35.6 & 35.89 \\
\hline U1318B-5H-6, 65 & 41.65 & 41.94 & Tie to & U1318A-5H-2, 82 & 40.03 & 41.94 \\
\hline U1318A-5H-4, 5 & 42.75 & 44.66 & Tie to & U1318B-6H-1, 35 & 43.35 & 44.66 \\
\hline U1318B-6H-5, 90 & 49.9 & 51.21 & Tie to & U1318A-6H-2, 120 & 49.9 & 51.21 \\
\hline U1318A-6H-6, 20 & 54.9 & 56.21 & Tie to & U1318B-7H-2, 60 & 54.6 & 56.21 \\
\hline U1318B-7H-6, 150 & 61.51 & 63.12 & Tie to & U1318A-7H-3, 106 & 61.26 & 63.12 \\
\hline U1318A-7H-5, 35 & 63.55 & 65.41 & Tie to & U1318B-8H-1, 145 & 63.45 & 65.41 \\
\hline U1318B-8H-6, 50 & 70 & 71.96 & Tie to & U1318A-8H-3, 20 & 69.37 & 71.96 \\
\hline U1318A-8H-5, 105 & 73.22 & 75.81 & Tie to & U1318C-2H-2, 85 & 72.35 & 75.81 \\
\hline U1318C-2H-7, 50 & 79 & 82.46 & Tie to & U1318A-9H-3, 75 & 79.95 & 82.46 \\
\hline U1318A-9H-5, 50 & 82.7 & 85.21 & Tie to & U1318C-3H-1, 65 & 80.15 & 85.21 \\
\hline U1318C-3H-7, 50 & 88.7 & 93.76 & Tie to & U1318A-10H-4, 141 & 91.11 & 93.76 \\
\hline U1318A-10H-6, 10 & 92.8 & 95.45 & Tie to & U1318C-4H-1, 150 & 90.5 & 95.45 \\
\hline U1318C-4H-6, 85 & 97.35 & 102.3 & Tie to & U1318A-11H-4, 13.5 & 99.84 & 102.3 \\
\hline U1318A-11H-6, 20 & 102.9 & 105.36 & Tie to & U1318B-12H-2, 125 & 102.75 & 105.36 \\
\hline U1318B-12H-6, 25 & 107.75 & 110.36 & Tie to & U1318A-12H-3, 75 & 107.95 & 110.36 \\
\hline U1318A-12H-5, 100 & 111.2 & 113.61 & Tie to & U1318C-6H-1, 150 & 109.5 & 113.61 \\
\hline U1318C-6H-5, 5 & 114.05 & 118.16 & Tie to & U1318B-13H-4, 90 & 114.9 & 118.16 \\
\hline U1318B-13H-6, 40 & 117.4 & 120.66 & Tie to & U1318A-13H-3, 125 & 118.45 & 120.66 \\
\hline U1318A-13H-5, 60 & 120.8 & 123.01 & Tie to & U1318B-14H-1, 115.5 & 120.17 & 123.01 \\
\hline U1318B-14H-6, 25 & 126.58 & 129.42 & Tie to & U1318A-14H-3, 32 & 126.53 & 129.42 \\
\hline U1318A-14H-3, 135 & 127.55 & 130.44 & Tie to & U1318C-8X-1, 27.5 & 126 & 130.44 \\
\hline U1318C-8X-7, 40.4 & 135.02 & 139.46 & Append to & U1318C-9X-1, 0 & 135.3 & 139.74 \\
\hline U1318C-9X-7, 47.9 & 144.78 & 149.22 & Append to & U1318C-10X-1, 0 & 144.9 & 149.34 \\
\hline U1318C-10X-6, 75 & 153.15 & 157.59 & Tie to & U1318B-17X-5, 75 & 154.45 & 157.59 \\
\hline U1318B-17X-7, 42.8 & 157.13 & 160.27 & Append to & U1318B-18X-1, 0 & 157.3 & 160.44 \\
\hline U1318B-18X-6, 132.7 & 166.63 & 169.77 & Append to & U1318B-19X-1, 0 & 166.9 & 170.04 \\
\hline U1318B-19X-8, 48.7 & 176.39 & 179.53 & Append to & U1318B-20X-1, 0 & 176.5 & 179.64 \\
\hline U1318B-20X-7, 145 & 185.95 & 189.09 & Append to & U1318B-21X-1, 0 & 186.1 & 189.24 \\
\hline U1318B-21X-7, 137.2 & 195.47 & 198.61 & Append to & U1318B-22X-1, 0 & 195.7 & 198.84 \\
\hline U1318B-22X-8, 54.9 & 205.25 & 208.39 & Append to & U1318B-23X-1, 0 & 205.2 & 208.34 \\
\hline U1318B-23X-7, 70 & 214.6 & 217.74 & Append to & U1318B-24X-1, 0 & 214.7 & 217.84 \\
\hline U1318B-24X-6, 103.4 & 223.23 & 226.37 & Append to & U1318B-25X-1, 0 & 223.7 & 226.84 \\
\hline U1318B-25X-3, 80 & 227.5 & 230.64 & Append to & U1318B-26X-1, 0 & 228.3 & 231.44 \\
\hline U1318B-26X-2, 158.6 & 231.4 & 234.54 & Append to & U1318B-27X-1, 0 & 235 & 238.14 \\
\hline U1318B-27X-5, 52.6 & 241.03 & 244.17 & & & & \\
\hline
\end{tabular}


Table T11. Logging operations, Hole U1318A.

\begin{tabular}{ccl}
\hline $\begin{array}{c}\text { Date } \\
\text { (May 2005) }\end{array}$ & $\begin{array}{c}\text { Local } \\
\text { time }(\mathrm{h})\end{array}$ & \multicolumn{1}{c}{ Comments } \\
\hline 10 & 1030 & Hole preparation complete, rig up triple combo (HNGS-APS-HLDS-DIT-EMS-TAP) \\
10 & 1130 & $\begin{array}{l}\text { Run into hole with triple combo } \\
10\end{array}$ \\
1310 & Uplog with triple combo at $900 \mathrm{ft} / \mathrm{h}$ from total depth \\
10 & 1350 & Pull tools out of hole and rig down \\
10 & 1515 & Rig up FMS-sonic (SGT-DSI-GPIT-FMS) \\
10 & 1600 & Run into hole with FMS-sonic \\
10 & 1705 & First pass with FMS at 900 ft/h from total depth \\
10 & 1740 & Going down for main pass to seafloor \\
10 & 1755 & Uplog with FMS at 900 $\mathrm{ft} / \mathrm{h}$ from total depth \\
10 & 1855 & Pull tools out of hole and rig down \\
10 & 2000 & Clear rig floor of logging tools, sheaves, and wireline \\
10 & 2100 & End of logging operation \\
\hline
\end{tabular}

Notes: Drillers total depth $=664 \mathrm{mbrf}$, water depth $=409 \mathrm{~m}$, end of pipe $=70 \mathrm{mbsf}$, total cored depth $=242 \mathrm{mbsf}$, total logged depth $=242$ mbsf. HNGS = Hostile Environment Natural Gamma Ray Sonde, APS = Accelerator Porosity Sonde, HLDS = Hostile Environment Litho-Density Sonde, DIT = Dual Induction Tool, EMS = Environmental Measurement Sonde, TAP $=$ Temperature/Acceleration/Pressure tool, WST $=$ Well Seismic Tool, SGT = Scintillation Gamma Ray Tool, DSI = Dipole Sonic Imager, GPIT = General Purpose Inclinometry Tool, FMS = Formation MicroScanner. 